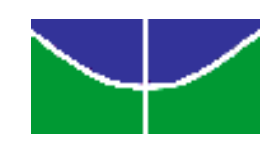

Universidade de Brasília Centro de Excelência em Turismo

\title{
O ARTESANATO LOCAL DE PIRENÓPOLIS - GO
}

Ludmilla Rodrigues Pimenta

Dr. ${ }^{a}$ Deis Siqueira

Monografia apresentada ao Centro de Excelência em Turismo da Universidade de Brasília como requisito parcial para obtenção do certificado de Especialista em Turismo: Cultura e Lazer

Brasília - DF, junho de 2005 
UNIVERSIDADE DE BRASÍLIA Centro de Excelência em Turismo

Curso de Especialização em Turismo: Cultura e Lazer

O ARTESANATO LOCAL DE PIRENÓPOLIS - GO

Ludmilla Rodrigues Pimenta

Banca Examinadora:

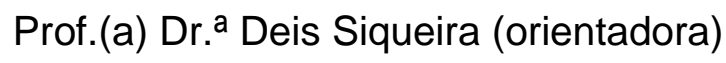

Prof.(a) Dr. ${ }^{a}$ Dulce Suassuna (membro)

Brasília - DF, junho de 2005 


\section{AGRADECIMENTOS}

Agradeço em primeiro lugar a Deus que me dá força e ânimo para enfrentar os obstáculos que encontro em minha vida;

A minha mãe querida, exemplo de luta, dedicação, amor e compreensão e que faz sempre o melhor para me dar boa educação;

A minha irmã que eu amo muito e é uma grande amiga;

Aos meus amigos que me acompanham sempre;

A minha professora e orientadora de monografia Deis Siqueira por seu acompanhamento e revisão de estudo;

Aos meus colegas de curso, os quais fizeram parte da minha vida acadêmica;

Aos meus professores por seus ensinamentos, que tanto contribuíram para o meu crescimento profissional;

Aos Artesãos de Pirenópolis - GO por suas contribuições e sensibilidade;

E também aos Órgãos Públicos que me ajudaram no processo de criação. 


\section{RESUMO}

A presente monografia refere-se ao Artesanato local de Pirenópolis-GO. Os principais objetivos foram: Realizar uma análise descritiva sobre o artesanato local de Pirenópolis; Identificar o artesanato local como fazendo parte da Cultura, da Tradição popular, da Identidade cultural e do Patrimônio imaterial da cidade e Verificar os principais tipos de artesanato existentes em Pirenópolis. Para este estudo, foram feitas consultas em livros, internet e materiais impressos de Órgãos públicos. Foram elaborados também roteiros de entrevistas semi-dirigidas contendo perguntas pertinentes e necessárias sobre o assunto. Em seguida estes roteiros de entrevistas foram aplicados aos principais artesãos de Pirenópolis, ao Secretário de Turismo de Pirenópolis, ao Presidente da Associação de Artesãos e Joalheiros de Pirenópolis (AJAP), ao MinTur, ao MinDIC, ao SEBRAE Nacional e a AGETUR. As informações foram gravadas e registradas por fotos. Com a análise de todos os dados e das entrevistas realizadas foi possível alcançar os objetivos propostos, ver a importância do artesanato local e sua contribuição para a expansão do Turismo em Pirenópolis-GO. Todavia este trabalho possibilita também conhecer um pouco da sensibilidade de cada artesão, valorizando e preservando suas raízes, cultura e tradições.

Palavras-chaves: Artesanato local, Patrimônio Imaterial, Tradição e Turismo 


\begin{abstract}
The present monograph refers to the local handicrafts of Pirenópolis-GO. The main objectives had been: To conduct a descriptive analysis on the local handicrafts of Pirenópolis; to identify the local handicrafts as being part of the Culture, the popular Tradition, the cultural Identity and the corporate Heritage of the city and to verify the main existing types of handicrafts in Pirenópolis. For this study, consultations in books, Internet have been made and materials printed by public Agencies. Scripts of semi-guided interviews have been elaborated also contend pertinent and necessary questions on the subject. After that, these scripts of interviews were applied to the main handicraft-producing people of Pirenópolis, to the Secretary of Tourism of Pirenópolis, to the President of the Associação de Joalheiros e Artesãos de Pirenópolis (AJAP), to the MinTur, the MinDIC, the National SEBRAE and the AGETUR. The information had been documented and registered by photograph. With the analysis of all the data and the interviews it was possible to reach the considered objectives, to prove the importance of the local handicrafts and its contribution for the expansion of tourism in PirenópolisGO. However, this work made it possible also to know a little of the sensitive faces of each handicraft- producing person, by valuing and preserving the origins, culture and traditions of Pirenópolis.
\end{abstract}

Key- Words: Local Handicrafts, Incorporeal Patrimony, Traditions and Tourism 


\section{LISTA DE FIGURAS}

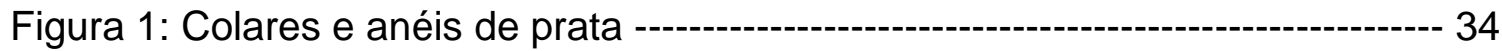

Figura 2: Anéis de prata ----- 34

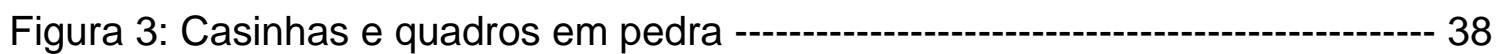

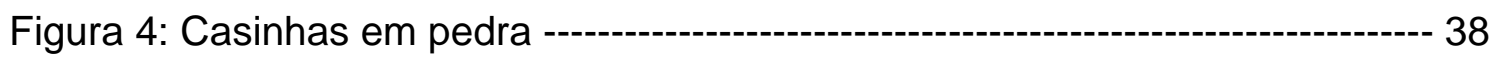

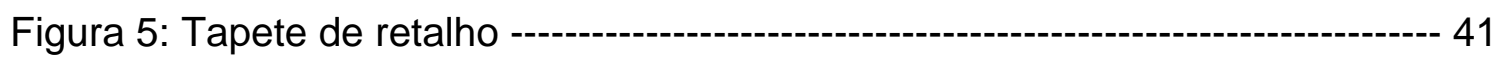

Figura 6: Colcha de retalho ------------------------------------------------------------------ 41

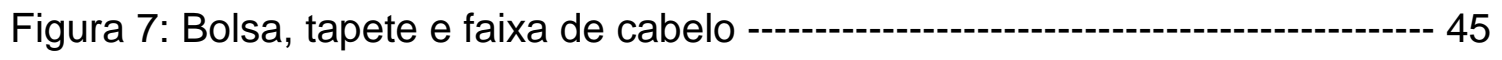

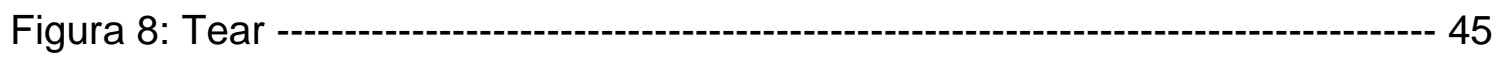

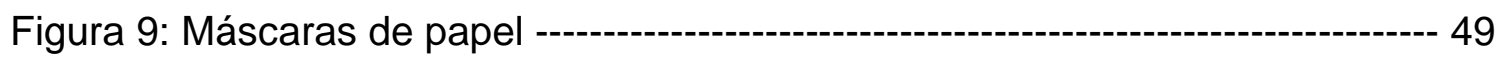

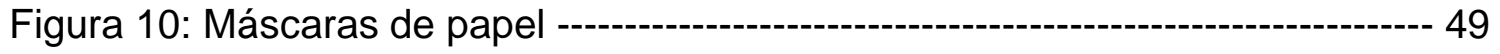

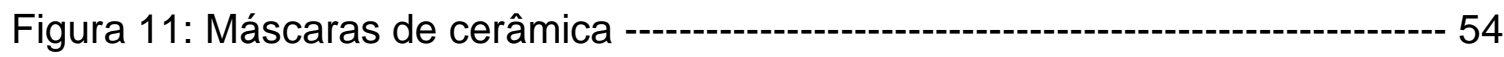

Figura 12: Panelas, cavalinho e máscara de cerâmica ----------------------------------54

Figura 13: Quadro da Igreja Nossa Senhora da Lapa ---------------------------------- 58

Figura 14: Quadro em fase de acabamento --- 58

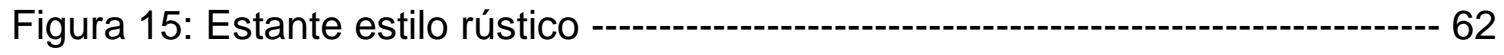

Figura16: Banco estilo rústico ----------------------------------------------------------------- 62

Figura 17: Doces de várias especialidades (leite, mamão, caju, ameixa, etc) ---- 66

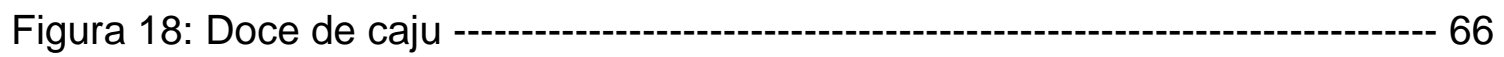

Figura 19: Associação dos Joalheiros e Artesãos de Pirenópolis (AJAP) --------- 81 
SUMÁRIO

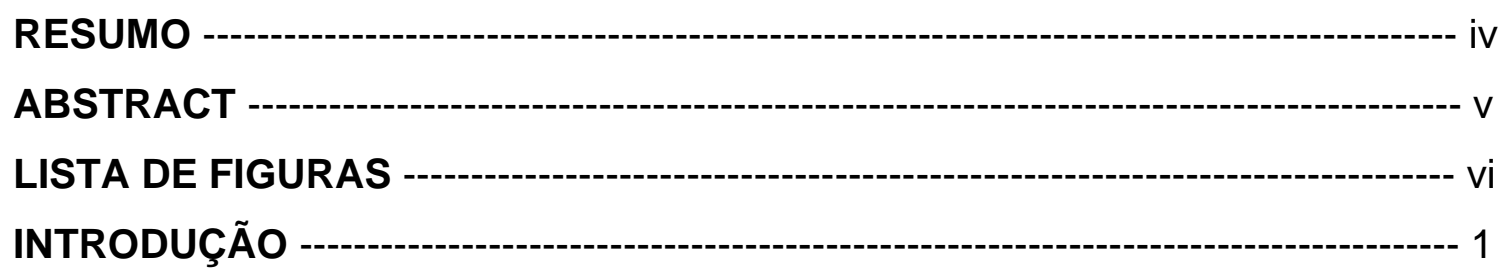

DISCUSSÃO DOS AUTORES, DOS ARTESÃOS DE PIRENÓPOLIS E DOS ÓRGÃOS PÚBLICOS

Capítulo I: Considerações teórico-metodológicas sobre comunidade, lugar, memória, tradição popular, identidade cultural, cultura, patrimônio material e

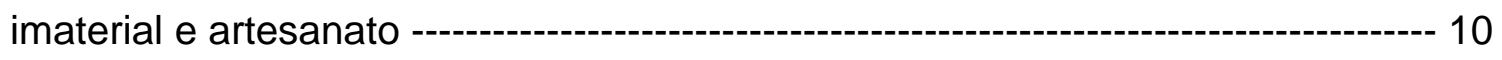

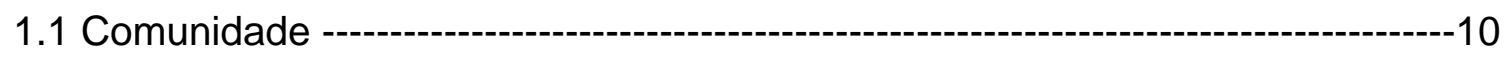

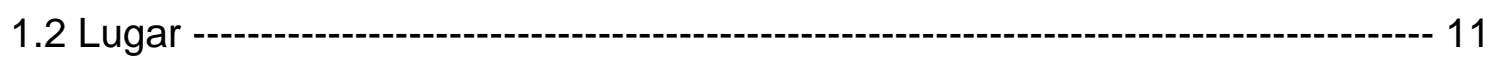

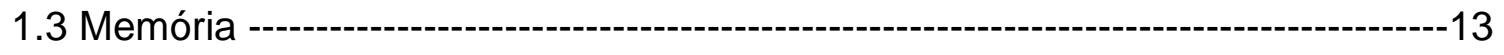

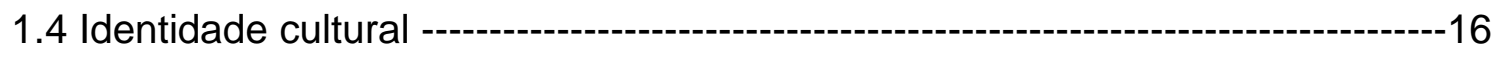

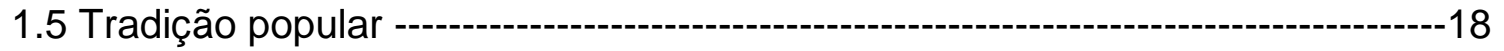

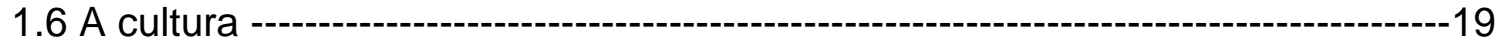

1.7 Patrimônio cultural (material e imaterial) ----------------------------------------------21

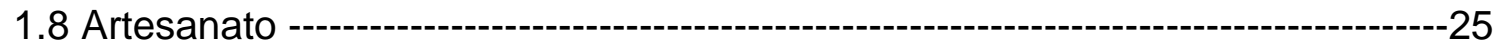

Capítulo II: Reflexão sobre o artesanato local de Pirenópolis-GO -------------------30

2. Os principais tipos de artesanato existentes em Pirenópolis ------------------------30

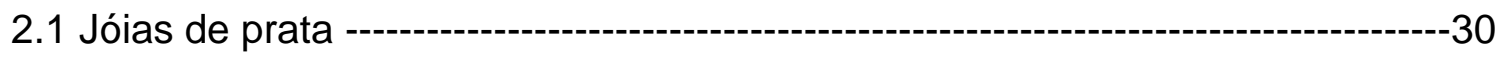

2.2 Escultura em pedra ------------------------------------------------------------------------ 35

2.3 Patchwork (Tapetes e colchas de retalho) ------------------------------------------ 39

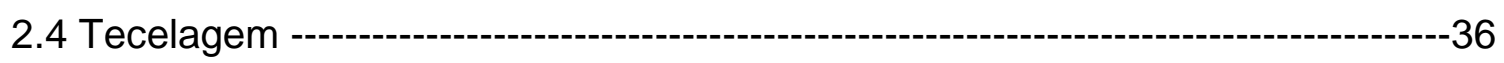

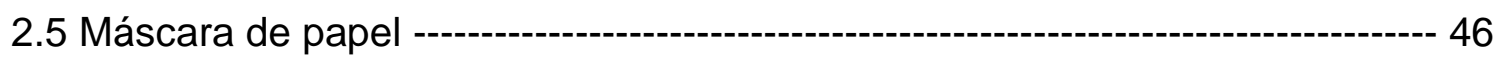

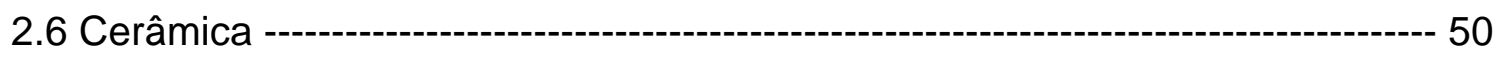

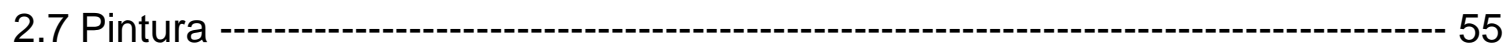

2.8 Móveis rústicos --------------------------------------------------------------------------------59

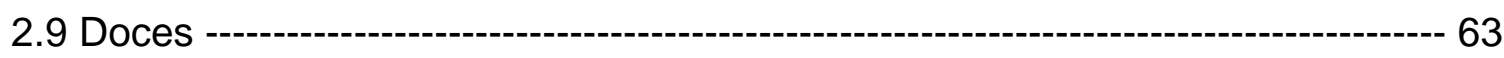


3. Análise das diferentes visões dos artesãos de Pirenópolis --------------------------67

4. Análise das diferentes visões dos órgãos públicos sobre artesanato ------------ 72

4.1 Secretaria de Turismo de Pirenópolis -- 72

4.2 Associação de Joalheiros e Artesãos de Pirenópolis (AJAP) -------------------- 77

4.3 Agência Goiana de Turismo (AGETUR) ------------------------------------------ 82

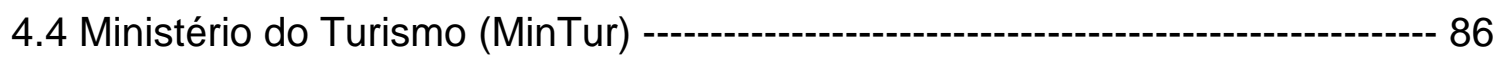

4.5 Ministério do Desenvolvimento, Indústria e Comércio Exterior (MinDIC) ----- 89

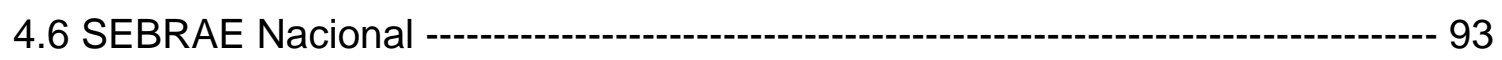

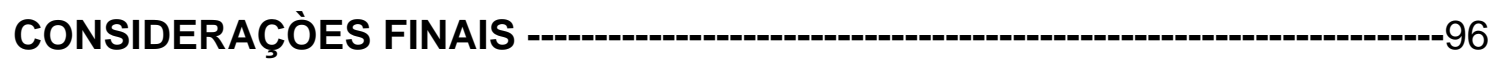

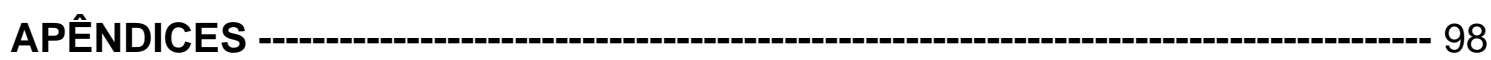

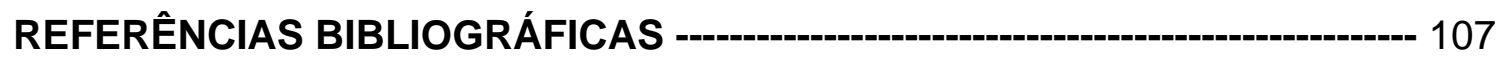

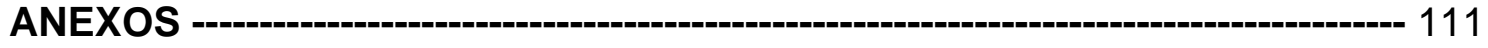




\section{INTRODUÇÃO}

Pirenópolis é uma cidade histórica, fundada em 1727 pelos Bandeirantes, que vieram em busca do ouro. O arraial foi criado nesta data e elevado a vila em 1832; a vila foi elevada à categoria de cidade em 1853, a qual se chamou Minas de Nossa Senhora do Rosário de Meia Ponte. "Meia Ponte" porque metade de sua ponte (sobre o Rio das Almas) foi levada por uma enchente. Em 1890, a cidade passou a se chamar Pirenópolis, por estar entre duas grandes elevações que formam a Serra dos Pireneus.

A cidade fica a 150 km de Brasília e a 120 km de Goiânia. Com aproximadamente 30 mil habitantes, localiza-se ao pé da Serra dos Pirineus, cadeia rochosa que atinge $1385 \mathrm{~m}$ de altura e que fica a $20 \mathrm{~km}$ do centro da mesma.

No século XVIII a cidade apresentava intensa atividade social, pois era o ponto de acesso a todas os caminhos de Goiás, entre eles as rotas para São Paulo, Minas Gerais e os sertões do Mato Grosso. Com o passar dos tempos Pirenópolis ainda mantém viva e expressiva sua cultura e suas tradições, seja elas, em sua gente simples e hospitaleira; nas centenas de casarões, igrejas e prédios históricos, de arquitetura colonial-barroca; nas inúmeras e belas cachoeiras e nas festas populares tradicionais, que atraem milhares de turistas de todos os lugares do Brasil e alguns estrangeiros todos os anos.

Entre os edifícios históricos destacam-se a Igreja da Matriz Nossa Senhora do Rosário, a mais antiga do Estado de Goiás, construída entre 1728 e 1732. Além da igreja da Matriz, também são importantes a Igreja do Nosso Senhor do Bonfim, construída em 1750; a Igreja e Museu Nossa Senhora do Carmo; o Teatro de Pirenópolis, de 1899; a casa da Rua Direita, de 1852; o Museu das Cavalhadas; a Fazenda Babilônia, construída no final do século XVIII, início do século XX e o Santuário de Vida Silvestre Vaga Fogo. (http:// www.pirenopolis.tur.br, acesso em: 7 jun. 2004) 
A Igreja da Matriz Nossa Senhora do Rosário é a igreja mais antiga do estado de Goiás e foi construída por escravos entre 1728 e 1732 com recursos provenientes da mineração do ouro. Suas paredes chegam a ter dois metros de espessura e o teto da capela foi pintado por artistas pirenopolinos. Tombada pelo Patrimônio Histórico desde 1941, foi restaurada em 1999, quando as pinturas foram recuperadas. Em setembro de 2002, a Matriz foi praticamente destruída por um incêndio e está sendo restaurada aos poucos.

A Igreja do Nosso Senhor do Bonfim foi construída por escravos entre 1750 e 1754. Seu construtor, o Sargento-Mor Antônio José de Campos e esposa, estão sepultados na capela-mor da igreja. A igreja abriga uma imagem em tamanho natural de Nosso Senhor do Bonfim, trazida da Bahia por 260 escravos em 1755, e é muito visitada por moradores e turistas.

A Igreja e Museu Nossa Senhora do Carmo também foi construída por escravos em 1750, e é uma igreja de estilo barroco, contendo peças de igrejas já demolidas. Recentemente foi adaptada para funcionar como Museu de Arte Sacra. (Em restauração).

O Teatro de Pirenópolis foi construído em 1899 e foi restaurado recentemente, nas comemorações do seu centenário. Foram preservados os desenhos e estruturas originais e criados espaços de apoio, como camarins e depósitos.

O Museu das Cavalhadas é um museu particular onde são guardados roupas e adereços de uma das festas mais tradicionais da cidade, as Cavalhadas.

A Fazenda Babilônia está localizada a $26 \mathrm{~km}$ da cidade, é uma das mais antigas do Estado de Goiás e foi considerada um importante engenho de cana-de-açúcar no passado. É um casarão em estilo colonial tombado pelo IPHAN. 
O Santuário de Vida Silvestre Vaga Fogo é uma Reserva Particular de Patrimônio Natural (RPPN) e está localizado a $6 \mathrm{~km}$ da cidade. O Santuário margeia o Ribeirão Vaga Fogo e abriga uma grande variedade de pássaros e animais silvestres. Há também no Santuário um Centro de Visitantes, onde existem vídeos informativos e publicações sobre meio ambiente e preservação; e onde se oferece um Breakfast, com geléias e doces típicos da região.

\begin{abstract}
As cachoeiras localizam-se entre 5 e $15 \mathrm{~km}$ da cidade e as mais conhecidas são: Reserva Ecológica Vargem Grande, onde encontram-se duas grandes cachoeiras, a do Lázaro e a de Santa Maria. Elas estão na fazenda do Lázaro, na região da Serra dos Pireneus; a fazenda Bonsucesso, onde há seis cachoeiras, sendo que as mais visitadas são, as cachoeiras do Aladim, a Tamboril e a Azul; Cachoeira do Abade, situada na fazenda Cabaçais; Cachoeiras Meia Lua e Fumaça, localizadas na fazenda Meia Lua; Cachoeira Usina Velha, onde funcionava a antiga usina de fornecimento de energia, etc. (http:// www.pirenopolis.tur.br, acesso em: 7 jun. 2004)
\end{abstract}

Dentre as festas populares, destaca-se a Festa do Divino Espírito Santo, que acontece 50 dias após a Semana Santa. A festa constitui-se de Novena, Folia, Procissão, Roqueira (tiro de Roca), Cavalhadas e Pastorinhas. As Cavalhadas é considerada uma das maiores atrações folclóricas da América do Sul e é a representação simbólica da história de luta, travada pelos mouros e cristãos, no século 8. Há também a Romaria à Serra dos Pireneus, na $1^{\mathrm{a}}$ semana de julho.

A cidade de Pirenópolis tem intensa atividade turística nas temporadas de Janeiro, Julho e Dezembro, finais de semana e feriados, proporcionando uma acolhedora estrutura para os turistas, principalmente no que se referem à gastronomia, meios de hospedagem e artesanato local, onde se destacam as cerâmicas, os móveis de madeira, as colchas bordadas, os doces, os crochês, as máscaras de papel, até os introduzidos pelos estrangeiros, como as jóias de prata, e que fazem parte da cultura da mesma. 


\section{A CULTURA}

"A palavra cultura, em seu uso corrente, significa saber, estudo, elegância, esmero; ela evoca os domínios da filosofia, das ciências e das belas artes". (Arantes, 1990, p. 30)

Pode-se entender então, a cultura como uma forma de expressão que abrange os objetos, conhecimentos, valores, costumes e celebrações que fazem parte do modo de vida do povo, categoria social complexa e de definição imprecisa.

De acordo com Arantes (1990, p. 32):

A cultura popular surge como uma outra cultura que, por contraste ao saber culto dominante, apresenta-se como totalidade, embora sendo, na verdade, construída através da justaposição de elementos residuais e fragmentários, considerados resistentes a um processo natural de deterioração. Desse modo, interpretar o significado das culturas, implica em reconstituir, em sua totalidade, o modo como os grupos se representam e as relações sociais que os definem enquanto tais.

A cultura é a manifestação mais sincera de um povo. Sendo que cada estado, país ou região possui a sua. E é esta diversidade cultural, somada, dota os diferentes povos de belezas ímpares. Belezas estas que são passadas de geração a geração, fazendo com que as tradições sejam respeitadas e preservadas.

O PATRIMÔNIO IMATERIAL

A UNESCO define Patrimônio imaterial como:

O conjunto das manifestações culturais, tradicionais e populares, ou seja, as criações coletivas, emanadas de uma comunidade, fundada sobre a tradição. Elas são transmitidas oral e gestualmente, e modificadas através do tempo por um processo de recriação coletiva. Integram esta modalidade de patrimônio as línguas, as tradições orais, os costumes, a música, a dança, os ritos, os festivais, a medicina tradicional, as artes da mesa e o "saber fazer" dos artesanatos e das arquiteturas tradicionais. 
O patrimônio imaterial é um bem cultural que possui uma autencidade, um valor e uma identidade única. É um bem de caráter coletivo, intangível e constitui a riqueza e a herança de um povo.

\section{O ARTESANATO}

Artesanato pode ser definido como a execução de trabalho manual, com ou sem ajuda de ferramentas e técnicas caseiras, que as pessoas dão às matérias-primas, sobras e lixo do consumo industrial, visando produzir peças utilitárias, artísticas e recreativas, com ou sem fim comercial.

Os diversos tipos de artesãos:

- Artesão-artista: é aquele que por sua criatividade, originalidade, produz peças que provoquem admiração e sensibilidade naqueles que as observam. Exemplo: talhadores, gravadores, escultores, etc;

- Artesão-artesão: é aquele que trabalha em série, com ou sem a ajuda de ferramentas e mecanismos caseiros, produzindo inúmeras peças. Este tipo de artesão está mais preocupado com a utilidade das peças que produz. Exemplo: Cerâmica ornamentada produzida manualmente com ou sem torno de pé;

- Artesão semi-industrial: é aquele que trabalha a partir de moldes ou através de processos semi-industriais, reproduzindo várias peças iguais. Exemplo: Peças utilitárias de cerâmica produzida de forma semi-industrial (tigelas, jarros, potes, etc).

O artesanato pode ser classificado da seguinte maneira:

- Quanto à predominância da matéria-prima usada: couro, vidro, metais, argila, gesso, madeira, tecido, etc;

- Quanto à origem: indígena, rural e urbana;

- Quanto à fonte de matéria-prima: matéria-prima natural, matéria prima industrial, sobras e lixos industriais;

- Quanto à utilidade: implemento, utensílio, adorno, decorativo, religioso, recreativo, lúdico, terapêutico, comestível, artístico, pedagógico;

- Quanto à forma: figurativo e não-figurativo;

- Quanto ao destino econômico: comercial e não-comercial.

(http:// www.eba.ufmg.br/alunos/kurtnavigator/arteartesanato/artesanato, acesso em: 20 set. 2004) 
O artesanato local de Pirenópolis é considerado uma das formas mais expressivas da arte de seu povo, com significados e diferentes usos. Pode ser identificado como a manifestação da cultura popular, de profunda criatividade e valores. Ele preserva as raízes de um povo, contribui para o desenvolvimento de uma comunidade e o aumento do turismo, podendo trazer também o crescimento sustentável da cidade. Portanto seria importante um estudo detalhado sobre este tema.

O presente trabalho tem por objetivos: realizar uma análise descritiva sobre 0 artesanato local de Pirenópolis; a) verificar os principais tipos de artesanato existentes em Pirenópolis e b) compreender o significado do artesanato para os artesãos de Pirenópolis e para os órgãos públicos.

Diante dos objetivos propostos apresentam-se os seguintes problemas de investigação: a) Quais são os principais tipos de artesanato existentes em Pirenópolis? e b) O que representa o artesanato local para os artesãos de Pirenópolis e para os órgãos públicos?

Aos problemas apresentados indica-se as seguintes hipóteses: a) Os principais tipos de artesanato existentes em Pirenópolis são: cerâmica, escultura em pedra, tapetes e colchas de retalho, tecelagem, máscara de papel, móveis rústicos, jóias de prata, pinturas e doces e b) $\mathrm{O}$ artesanato local representa o Patrimônio imaterial da cidade, faz parte da Cultura, da Tradição popular e da Identidade cultural, porém não é reconhecido como tal pelas autoridades.

O trabalho, com abordagem qualitativa, teve como delineamento o estudo de caso, realizado em Pirenópolis-GO. Para tanto, foram definidas as seguintes etapas: a) pesquisa bibliográfica, na qual foram coletadas informações sobre comunidade, lugar, memória, cultura, patrimônio material e imaterial, bens culturais, tradição popular, identidade cultural e artesanato, por meio de livros e internet; b) pesquisa documental, na qual utilizou-se materiais impressos de 
órgãos públicos e c) pesquisa de campo. Na pesquisa de campo utilizou-se como técnica, roteiros de entrevistas semi-dirigidas e as informações foram gravadas e registradas por fotos.

Os públicos-alvo das entrevistas foram as lideranças dos principais tipos de artesanato existentes em Pirenópolis; o Presidente da Associação de Joalheiros e Artesãos de Pirenópolis (AJAP); o Secretário de Turismo de Pirenópolis e as autoridades governamentais. Durante a pesquisa tentou-se entrevistar a coordenadora de artesanato do SEBRAE do Estado de Goiás, a Presidente do Programa de Artesanato Brasileiro do Estado de Goiás e a coordenadora do Patrimônio Imaterial do IPHAN Nacional, mas, todavia, obteve-se como resposta a recusa.

Para a pesquisa foi utilizado o cadastro de artesãos da Associação de Joalheiros e Artesãos de Pirenópolis (AJAP). Deste cadastro a pesquisadora entrevistou as lideranças dos principais tipos de artesanato existentes em Pirenópolis-GO e também entrevistou algumas lideranças que não estavam cadastradas na AJAP. O cadastro da AJAP foi utilizado em um primeiro instante, devido a maior quantidade de artesãos (185 cadastrados). Em um segundo instante, a pesquisadora teve que entrevistar algumas lideranças não cadastradas na AJAP, pois nem todos os tipos de artesanato estavam no cadastro da AJAP.

Os dados foram coletados por meio de livros; entrevistas em Pirenópolis; no Ministério do Turismo (MinTur); no Ministério do Desenvolvimento, Indústria e Comércio Exterior (MinDIC); no SEBRAE Nacional e na Agência Goiana de Turismo (AGETUR). As entrevistas em Pirenópolis com os artesãos, com o Secretário de Turismo de Pirenópolis e com o Presidente da Associação de Joalheiros e Artesãos (AJAP), aconteceram nos dias 29, 30 e 31 de março de 2005. Já as entrevistas no MinTur, no MinDIC e no SEBRAE Nacional aconteceram nos dias 5 e 6 de abril de 2005. E por fim, a entrevista na AGETUR que aconteceu no dia 18 de maio de 2005. 
Os principais autores utilizados para melhor compreensão dos resultados foram: Antônio Augusto Arantes (1990), Margarita Barreto (2002), João Lanari Batista Bo (2003), Mário Carlos Beni (2001), Graça Coutinho (2001), Aurélio Buarque de Holanda Ferreira (2004), Pedro Paulo Funari e Jaime Pinsky (2003), Álvaro Banducci Júnior e Margarita Barreto (2001), Roque de Barros Laraia (1993), Aloísio Magalhães (1997), Marc Auge (1994), Durcelice Cândida Mascêne, et al (orgs) (2004), Rodrigo de Azeredo Grunewald (2001), Cecília Londres (2001), Cecília Londres e João Gabriel L. C. (2004), Ruben George Oliven (2003), Letícia Vianna (2004), Glenn F Ross (2001), Márcia Sant'anna (2003), alguns sites e os professores Mariza Veloso e Carlos Delphim, que contribuíram na discussão tratando dos temas: comunidade, lugar, turismo, cultura, memória, tradição popular, identidade cultural, patrimônio material e imaterial e artesanato.

O resultado da pesquisa foi apresentado ao longo das discussões propostas, em capítulos: Capítulo I: Considerações teóricas sobre comunidade, lugar, memória, identidade cultural, tradições populares, cultura, patrimônio material e imaterial e artesanato e o Capítulo II: Reflexão sobre o artesanato local de Pirenópolis-GO.

Para facilitar e identificar os entrevistados no decorrer da pesquisa, segue-se na página seguinte uma tabela com a relação dos artesãos e órgãos públicos. 
Relação de Artesãos entrevistados:

\begin{tabular}{c|l|l} 
Entrevista & Nome do entrevistado & Tipo de artesanato \\
\hline $1^{\mathrm{a}}$ & Balduíno Valério Pereira & Jóias de prata \\
\hline $2^{\mathrm{a}}$ & Roque Pereira Pinto & Escultura em pedra \\
\hline $3^{\mathrm{a}}$ & Maria Conceição da Silva & Tapetes e colchas de retalho \\
\hline $4^{\mathrm{a}}$ & Mercedes Monteiro & Tecelagem \\
\hline $5^{\mathrm{a}}$ & João Luiz Pompeu de Pina & Máscaras de papel \\
\hline $6^{\mathrm{a}}$ & Lunildes de Oliveira Abreu & Cerâmica \\
\hline $7^{\mathrm{a}}$ & Pércio Forzani & Pintor \\
\hline $8^{\mathrm{a}}$ & Élio Souza Lobo & Movéis rústicos \\
\hline $9^{\mathrm{a}}$ & Doraluzia de Oliveira Goulão & Doces
\end{tabular}

Relação de funcionários de Órgãos públicos entrevistados:

\begin{tabular}{|c|c|c|}
\hline Entrevista & Nome do entrevistado & Órgão público \\
\hline $10^{\mathrm{a}}$ & Evandro Engel Ayer & Secretário de Turismo de Pirenópolis \\
\hline $11^{\mathrm{a}}$ & Balduíno Valério Pereira & $\begin{array}{l}\text { Presidente da Associação de Joalheiros } \\
\text { e Artesãos de Pirenópolis - AJAP }\end{array}$ \\
\hline $12^{\mathrm{a}}$ & Mariana Barreto Veloso & $\begin{array}{l}\text { Estagiária da Gerência da Articulação } \\
\text { privada da AGETUR }\end{array}$ \\
\hline $13^{a}$ & Ana Zerbini & Consultora de Artesanato do MinTur \\
\hline $14^{\mathrm{a}}$ & Tatiana Silva Novato & Auxiliar Administrativa do PAB - MinDIC \\
\hline $15^{\mathrm{a}}$ & Durcelice Cândida Mascêne & $\begin{array}{l}\text { Assessora do Departamento de } \\
\text { Desenvolvimento Setorial do SEBRAE }\end{array}$ \\
\hline
\end{tabular}




\section{DISCUSSÃO DOS AUTORES, DOS ARTESÃOS DE PIRENÓPOLIS E DOS ÓRGÃOS PÚBLICOS}

Capítulo I: Considerações teóricas sobre comunidade, lugar, memória, identidade cultural, tradição popular, cultura, patrimônio material e imaterial e artesanato

Os conceitos serão introduzidos e discutidos pelos autores e pelo pesquisador para um melhor esclarecimento e entendimento da cultura local da comunidade e dos artesãos de Pirenópolis.

\subsection{Comunidade}

O conceito de comunidade foi importante para reconhecer qual o grupo que seria pesquisado no decorrer da pesquisa. E o grupo pesquisado, no caso, foram as lideranças dos principais tipos de artesanato existentes em Pirenópolis.

Entende-se por comunidade um grupo de pessoas que exercem atividades afins, com características específicas e individualizantes: a comunidade médica, a comunidade dos comerciantes; ou a um grupo de pessoas que praticam a mesma crença religiosa: a comunidade católica, a comunidade espírita; ou a um grupo de pessoas que vivem submetidas a um mesmo objetivo e ideal de vida.

"Comunidade é qualquer grupo social que habita determinada região, tem o mesmo governo e está irmanada por uma herança cultural e histórica. É qualquer conjunto populacional considerado a partir de aspectos geográficos, econômicos ou culturais comuns". (http://mail.faac.unesp.br/ pcampos/oqueecomunidade.htm)

Segundo Ferreira (2004, p.162): "Do ponto de vista social, comunidade é o agrupamento social que se caracteriza por forte coesão baseada no consenso espontâneo dos indivíduos". 
Portanto a comunidade, ou seja, o agrupamento social é representado pelos objetivos em comum e atitudes sobre uma realidade social.

De acordo com Ross (2001, p. 137):

\begin{abstract}
As representações sociais são sistemas de pensamento partilhados por um grande número de membros da comunidade e as formas pelas quais eles ordenam a realidade da comunidade e fornecem códigos ou linguagem para facilitar a interação social. São formas de pensar e linguagem partilhadas, por meio das quais os membros da comunidade podem classificar inequivocamente, os vários aspectos de seu mundo e da história da comunidade.
\end{abstract}

Ao integrar-se em uma comunidade, o homem busca a aceitação do outro, a identificação do grupo, o fortalecimento da união. Isto leva, de um modo geral, à solidariedade, ao apoio mútuo, ao sentimento de grupo, de unidade, a ações coletivas. Já as ações coletivas, por sua vez, são desenvolvidas para estabelecer uma boa convivência entre os grupos.

"As oportunidades de promover relações com amigos, a coesão da comunidade, a tomada de decisões grupais, espaços abertos, clima e topografia foram sugeridos como fatores que contribuem para a avaliação geral do residente, sobre a prosperidade da vida da comunidade". (Ross 2001, p. 138)

O que o autor quis dizer, é que as relações que as comunidades mantêm, as decisões em conjunto, os espaços e os lugares onde se encontram, contribuem para melhorar ou interferir na vida de uma determinada comunidade. Portanto, o que pôde-se observar é que a comunidade sofre influência do lugar onde se encontram.

\title{
1.2 Lugar
}

O conceito de lugar foi analisado para delimitar o espaço que seria pesquisado, e o espaço foi toda a zona urbana, onde se concentram todos os artesãos da cidade. 
Os lugares são marcas da identidade, uma fisionomia que pode ser reconhecida por diferentes tribos, ou seja, por diferentes grupos sociais. São nos lugares que se ocorre as práticas coletivas, pois explora a vida moderna, as tradições, a cultura de um povo, etc.

Augé (1994) define um não-lugar como um espaço organizado que não garanta identidade, relações e história. Enquanto o lugar caracteriza-se por garantir simultaneamente identidade, relações e história aos membros do grupo cuja cultura o constituiu. Portanto, o lugar é um espaço, um território o qual os grupos mantêm relações com suas famílias e com os outros. E estas relações dependem das posições que estes mesmos grupos ou indivíduos ocupam no sistema. 0 espaço pode ser definido então, como espaço público, onde todos têm o direito de exercer a palavra e a ação. E é no espaço público que há uma troca de conhecimentos entre as pessoas.

Veloso (2004) em sua apostila: Apropriação de Espaços no Lazer e no Turismo comenta que os espaços são criados através do desenvolvimento das cidades, das trocas de conhecimentos, das práticas culturais, dos lugares e do turismo. Surge, portanto espaços como museus, teatros, feiras, etc.

A cidade pode ser compreendida como uma construção sobre a natureza, com o intuito de fixar o homem, garantir seu domínio sobre um determinado território e ensiná-lo à vida coletiva. As cidades são movidas por informações, serviços, relações sociais, urbanização, ou seja, pela modernidade. E é esta modernidade que faz com que as cidades cresçam e se desenvolvam.

Os lugares também são formados por memórias, pois são por meio delas que uma sociedade se organiza, se estrutura e obtêm-se informações de fatos acontecidos no passado. 


\title{
1.3 Memória
}

O conceito de memória foi discutido, pois é através dela que o artesanato de Pirenópolis foi armazenado e passado a gerações presentes e será repassado a gerações futuras.

Para Coutinho (2001, p. 103):

\begin{abstract}
A memória é, em primeiro lugar, uma faculdade de conservar os vestígios do que pertence a uma época passada. No homem, os vestígios do passado podem ser transmitidos sob a forma de criações exteriores ao próprio organismo, capazes de uma existência autônoma. É o caso dos relatos que passam de narrador a narrador, conservando a sua identidade, com algumas poucas variantes.
\end{abstract}

Pode-se entender por memória a aquisição, o armazenamento e a lembrança de informações ou fatos. A memória é, portanto, um dos caminhos para o conhecimento do passado, pois é através das lembranças, que recuperamos acontecimentos anteriores, distinguimos o ontem de hoje e confirmamos que já vivemos um passado. Esta confirmação, por sua vez, nos confere um sentido de identidade, pois saber o que fomos, confirma o que somos.

A memória trata-se da construção de referenciais sobre o passado e o presente de diferentes grupos sociais, ancorados nas tradições e intimamente associados a mudanças culturais.

De acordo com Veloso (2004, p.33): “A memória é interpretada não só através de seus mecanismos de rememoração, mas também como possibilidade de invenção e conquista. Assim memória pode ser nômade e repor, permanentemente, a dialética entre memória e esquecimento".

Dessa forma, memória não é só uma lembrança do que aconteceu, ela pode ser passada a gerações futuras, inventadas, conquistadas e não fica presa a determinado local. Podendo estar associada também ao tempo e ao espaço. Por 
sua vez, as memórias dos grupos se referenciam, nos espaços em que habitam e nas relações que constroem com estes espaços.

Para a memória ser compreendida melhor, deve-se analisá-la por partes: memória individual e memória social ou coletiva.

Segundo Coutinho (2001, p. 103):

A memória individual permite imitar certos comportamentos aprendidos quando se apresenta uma situação a que esses comportamentos estão associados. Adquire no homem dimensões e possibilidades novas, pelo fato de ele procurar objetos e de se comunicar com os seus semelhantes e com o mundo, não apenas através dos órgãos dos sentidos, mas também através da linguagem.

A memória individual pode ser entendida como uma forma dos indivíduos estabelecerem um contato entre presente e passado, permitindo-os uma comunicação com o mundo. Esta comunicação se dá através da linguagem e dentro de uma sociedade. Com isso surge a memória social ou coletiva.

"A memória coletiva se faz do conjunto de memórias individuais, que, guardados no inconsciente, revelam, em algum momento, um conjunto de ações ou comportamentos de determinado segmento da sociedade". (Coutinho, 2001, p.104)

Para Funari e Pinsky (2003, p. 18):

A memória social aflora, assim, como portadora de historicidade. As condições de construí-la são imutáveis e ela reflete as relações políticas, de possibilidades de exercício de direitos, que cada segmento social e também cada indivíduo tem em determinado tempo. Reflete também, a valorização que a sociedade dá ao passado. Ela será tão mais significativa quanto mais representar o que foi vivido pelos diversos segmentos sociais e quanto mais mobilizar o mundo afetivo dos indivíduos, suscitando suas lembranças particulares.

Portanto a memória coletiva ou social deve ser compreendida como fenômeno construído pela comunidade e que sofre transformações e modificações ao longo 
do tempo. Pode refletir também os valores que a sociedade dá ao passado e pode estar relacionada às recordações de um fato ou algum acontecimento importante.

Sant'anna (2003, p. 46) em seu texto diz:

Preservar a memória de fatos ou idéias, por meio de construtos que as comemoram, narram ou representam, é uma prática que diz respeito a todas as sociedades humanas. É, pode-se dizer, um universo cultural e é essa função memorial que está por trás da noção de monumento em seu sentido original. Conceito, aliás, que se encontra vinculado ainda a uma produção simbólica, à instituição de um objeto como monumento por um grupo e à capacidade desse atuar sobre a memória coletiva. $\mathrm{O}$ monumento trabalha e mobiliza a memória coletiva por meio da emoção e da afetividade, fazendo vibrar um passado selecionado, com vistas à "preservar a identidade de uma comunidade étnica, religiosa, nacional, tribal ou familiar".

Portanto o que a autora quer dizer é que é importante preservar a memória, pois é por meio dela que as sociedades se constroem, o passado histórico é resgatado e as atividades culturais são conservadas.

Magalhães (1997, p. 75-76) comenta:

É preciso refletir um pouco sobre o conceito de memória nacional, guardada nos grandes depósitos de saber que são o Museu Nacional, a Biblioteca Nacional, o Arquivo público, os órgãos regionais. A memória nacional está nos livros, no trabalho do Instituto do Patrimônio Histórico, enfim, em todas as entidades que, ao longo do tempo, se ocupam do problema da trajetória histórica da nação. A memória nacional, portanto, não precisa ser procurada.

Refletindo de uma maneira geral, a memória precisa ser mais reconhecida e resgatada, sem descaracterizar os modos de vida e costumes de uma sociedade. É preciso que as pessoas tomem consciência do seu passado histórico, para que este seja preservado e passado para seus descendentes. Quando houver um reconhecimento da cultura nacional, haverá um resgate da identidade cultural.

A finalidade da memória seria então, a de valorizar a cultura local, ou seja, as origens de um povo, suas riquezas culturais, suas maneiras de pensar e agir. Com isso preservaria a identidade cultural. 
1.4 Identidade cultural

O conceito de identidade cultural foi analisado, pois o artesanato de Pirenópolis faz parte dos hábitos, dos valores, dos costumes e das festas da comunidade local e dos artesãos.

Para Bo (2003, p.27):

"Identidade cultural é o repertório de traços culturais por meio dos quais os membros de uma nação se identificam". Com isso, compreende-se que a identidade cultural é formada pelas características comuns, pelos hábitos, interesses em comum, as tradições, as crenças, os valores e os estilos de vida de um determinado grupo ou sociedade.

Conforme Barreto (2000, p. 45):

Na modernidade, a identidade passa a ser mais flexível, sujeita a mudanças e inovações e depende em grande parte da relação com os outros. A identidade manifesta-se na pertença a determinados grupos (religiosos, políticos) ou a papéis (ser mãe, ser professor). As pessoas passam a perceber que a identidade é uma construção social e que pode ser mudada.

Com o passar dos anos a identidade de determinados povos, comunidades ou grupos passam a ser inovada, transformada, e isso se deve em grande parte à interferência de outras culturas, das necessidades de se trabalhar e ter um sustento, e do turismo.

As comunidades locais passam a adaptar sua realidade ao mercado turístico, ou seja, começam a modificar suas práticas culturais, a comercializar produtos para atender às exigências dos turistas. Estas comunidades, na verdade, descobrem uma maneira de ganhar a vida e acabam se interessando pelo retorno econômico e financeiro que o turismo pode proporcionar. 
Segundo Barreto (2000, p. 45):

Na pós-modernidade, assiste-se a um processo de fragmentação. O sujeito pós- moderno possui múltiplas identidades, que coexistem e se manifestam em razão de fatores diversos, externos ou internos a ela; é parte integrante de uma sociedade, em grande medida determinado e moldado por sua história e por seu inconsciente; não tem um comportamento nem uma postura sempre iguais ao longo da vida e em todas as circunstâncias. A matriz contemporânea é a de um sujeito que reage e se comporta de formas diferentes em circunstâncias e grupos diferentes.

O que acontece hoje, na era pós-modernidade, é o surgimento de várias identidades, pois as pessoas procuram se identificar cada hora de uma maneira, conforme situações ou grupos que estejam em contato. Este comportamento é devido a uma sociedade que vive um processo intenso de mudanças.

Coutinho (2001, p. 105) considera que:

A perda da identidade pode ser ameaçada pela facilidade em que entram e saem informações, e a inevitável penetração da cultura estrangeira pode vir a colocar em risco a diversidade cultural. Conscientizar a comunidade do valor de seu produto ou saber se deverá caminhar junto com as ações relativas ao registro destas manifestações, não só porque as preserva, mas também porque as valoriza. Esta valorização se reflete também na auto-estima do cidadão que se conscientiza da sua importância e da sua eficaz contribuição na sociedade, tornando-se, assim, alerta às interferências danosas.

O que o autor comenta é que a identidade de uma determinada comunidade pode vir a ser prejudicada com a influência ou a interferência de uma outra cultura. $E$ que para isso não acontecer é necessário a conscientização da comunidade, a preservação dos valores e das tradições de um determinado lugar. Tradições estas que representam a cultura de uma comunidade ou grupo e que devem ser passadas para as próximas gerações. 


\title{
1.5 Tradição popular
}

O conceito de tradição popular foi discutido para esclarecer que o artesanato de Pirenópolis é passado de geração a geração e que contribuiu e ainda contribui para a formação da história goiana

Entende-se por tradição a expressão do conhecimento, as manifestações culturais, a riqueza cultural e a maneira de sentir e agir de determinado povo, comunidade ou país, e que é repassada a gerações futuras, com o intuito de valorizar e preservar a história deste mesmo povo.

De acordo com Veloso (2004, p.32): "A tradição ou as tradições manifesta-se através de práticas coletivas concretas que se inscrevem no cotidiano dos grupos sociais, definindo as marcações do tempo e do espaço e, principalmente, construindo as referências de lugar".

A tradição é, portanto, a cultura de um determinado povo, passada de pais para filhos, ou seja, é o saber que se produziu em determinada época e lugar, por determinados povos ou comunidades.

Coutinho (2001, p. 103) comenta:

\begin{abstract}
A tradição oral, que não conhece a escrita e é a memória transmitida através da linguagem, conserva as recordações o mais longamente possível, de modo a poder transmiti-las aos outros. Através da narrativa, o indivíduo torna-se o depositário das recordações de seus antepassados remotos, a quem nunca conheceu mortos muito antes do seu nascimento e também as transmitem aos seus descendentes. Se a arte da narrativa é hoje rara, a difusão da informação é decisivamente responsável por seu declínio.
\end{abstract}

Mas hoje na era da pós-modernidade o que tem acontecido é a perda destas tradições ou sua modificação para atender o mercado turístico de determinados lugares. Para que esta perda não aconteça de maneira rápida, se faz necessária a 
conscientização da comunidade local sobre suas origens e valores e a ajuda dos órgãos públicos.

Magalhães (1997, p. 91) diz:

É óbvio que nos países ricos e desenvolvidos a tradição, o apego a esses valores fundamentais é algo secular, que se desenvolve ao longo do tempo e faz com que o nível de percepção e consciência desses valores seja muito nítido, enquanto que nos países jovens e pobres essa consciência é muito frágil, em muitos casos, até mesmo inexistente. A miséria, a pobreza, a ignorância, a doença são situações muito mais prioritárias, muito mais fortes, que põem em xeque a sobrevivência, que impedem que o ser humano vá socialmente além dessas questões, e aí a preservação passa a ser um luxo.

Portanto o que pode ser feito pelos órgãos são políticas adequadas de preservação das tradições, da cultura e do patrimônio cultural; cursos; palestras; oficinas de conscientização para as comunidades locais. E acima de tudo tentar melhorar a qualidade de vida destas comunidades, através da geração de empregos, pois só assim eles terão "cabeça" para pensar na preservação de suas origens.

A tradição, portanto faz parte da cultura de um determinado povo ou comunidade e é por meio dela que se preservam os valores e a história local.

\subsection{A Cultura}

O conceito de cultura foi analisado para melhor identificar o artesanato, como fazendo parte dos conhecimentos da comunidade de Pirenópolis. Conhecimento este, que a comunidade local está sempre adquirindo e repassando para os seus descendentes.

Cultura é tudo o que o ser humano produz em termos de ciência, arte, religião, ou seja, tudo o que ele constrói para viver ou detém de conhecimento. 
A cultura pode ser entendida também como sendo todas as práticas sociais (idéias, modos de vestir, de falar, de conhecimento, história, etc) de um determinado povo.

Delphim (2004, p.1) em seu texto comenta:

O conceito de cultura tem origem etimológica em cultivo e cultivo em culto. A primeira relação com o mundo natural, quando a humanidade apenas coletava os recursos que a terra lhe proporcionava, assumia a forma de um culto a uma entidade, boa ou má, conforme concedesse ou negasse aos homens os bens de que necessitavam. Posteriormente, passando a conhecer e dominar os recursos da natureza, domesticandoos e multiplicando-os conforme suas necessidades, adquire poderes até então restritos às divindades naturais, de multiplicação e produção desses recursos.

Cultura então, vem de agricultura, ou seja, cultivo da terra, uma época que a natureza dava o sustento ao ser humano. Depois o termo cultivar evoluiu para culto, e por fim para cultura como é conhecida hoje e tem vários significados.

Para Laraia (1993, p. 46):

O homem é o resultado do meio cultural em que foi socializado. Ele é um herdeiro de um longo processo acumulativo, que reflete o conhecimento e a experiência adquirida pelas numerosas gerações que 0 antecederam. A manipulação adequada e criativa desse patrimônio cultural permite as inovações e invenções.

Então a cultura pode ser entendida como movimento, ou seja, o homem está sempre adquirindo conhecimentos acerca de algo e repassando para outros. Pode ser entendida também como invenção e reinvenção dos conhecimentos, pois sofre interferências de grupos, comunidades ao longo dos tempos. Ela vai sendo modificada para atender as exigências de uma sociedade pós-modernista, onde os valores variam conforme a situação ou os lugares que as pessoas se encontrem. 
De acordo com Laraia (1993, p. 60):

\begin{abstract}
Culturas são sistemas (de padrões de comportamento socialmente transmitidos) que servem para adaptar as comunidades humanas aos seus embasamentos biológicos. Esse modo de vida das comunidades inclui tecnologias e modos de organização econômica, padrões de estabelecimento, de agrupamento social e organização política, crenças e práticas religiosas, e assim por diante.
\end{abstract}

Pela necessidade de se estudar a fundo a cultura, surgiu a antropologia, que é o estudo das diferentes culturas, e ela tenta mostrar que não existe uma cultura melhor ou superior a outra. Todas são importantes e contribuem para a formação da identidade cultural. E é está Identidade que constitui o patrimônio cultural de uma comunidade ou de um grupo.

\title{
1.7 Patrimônio cultural (material e imaterial)
}

O conceito de patrimônio foi importante para esta pesquisa, pois verificou-se que o artesanato é fabricado pelos artesãos de Pirenópolis, faz parte dos fazeres da comunidade local e é valorizado e repassado a gerações futuras.

Segundo Londres (2004, p.3):

"Patrimônio é tudo que criamos, valorizamos e queremos preservar: são os monumentos e obras de arte, e também as festas, músicas e danças, os folguedos e as comidas, os saberes, fazeres e falares. Tudo enfim que produzimos com as mãos, as idéias e as fantasias".

O patrimônio é uma herança que se adquire com o decorrer dos anos e é passada de pai para filho. Hoje tem um significado bem mais amplo, sendo considerado a consciência do passado, da história, da sociedade, dos valores, etc. Ele é composto pelos bens culturais de natureza material e imaterial. 
Delphim (2004, p. 3) comenta:

Do ponto de vista material, o patrimônio cultural de um povo são as obras, objetos, documentos, edificações, espaços utilizados para manifestações artístico-culturais, conjuntos urbanos e sítios de valor histórico, paisagístico, artístico, arqueológico, paleontológico, ecológico e científico. Já do ponto de vista imaterial, o patrimônio cultural inclui as formas de expressão de um povo, seus modos de criar, de fazer, de viver, de agir, seu conhecimento, costumes e instruções.

Estes bens fazem parte da história, da cultura e das tradições dos diferentes povos, tendo valores e significados distintos para cada um.

Sant'anna (2001, p. 160) considera que:

O conceito de patrimônio imaterial e sua interação com o patrimônio material contribuem para a sedimentação de uma idéia mais ampla de patrimônio cultural, enquanto síntese ou reunião desses dois aspectos. Um não faz sentido sem o outro, e um não pode ser completamente aprendido sem o outro. Um permanece mais longamente no tempo enquanto forma dada, o outro se transforma permanentemente e acaba. Um pode ser contemplado, o outro é apenas fugazmente aprendido, mas ambos são dinâmicos em sua interação e enquanto produtos da cultura.

Para a UNESCO (2003, p. 79):

O patrimônio intangível ou imaterial, incorpora aspectos tradicionalmente ligados ao artesanato popular e a dança e, virtualmente, à toda forma de "saberes e fazeres" transmitidos culturalmente no âmbito das comunidades. Resulta de reavaliação ocorrida no âmbito das ciências humanas, sobretudo na antropologia e nos estudos multiculturais, do estudo das tradições culturais populares e sua transmissão.

Portanto, o patrimônio material está focado nos bens materiais, ou seja, físicos, edificados, enquanto o patrimônio de natureza imaterial está focado na identidade, na memória e nos valores dos diferentes grupos ou comunidades que formam a identidade nacional.

Para que os bens culturais fossem bem cuidados, houve a necessidade de se criar um órgão, o Instituto do Patrimônio Histórico e Artístico Nacional (IPHAN). Este foi criado em 1937 com a finalidade de preservar o patrimônio cultural. 
Hoje a preservação é feita de duas maneiras: pelo tombamento (patrimônio material) e o registro (patrimônio imaterial). O tombamento foi o primeiro procedimento a ser tomado pelo IPHAN na preservação do patrimônio cultural e só mais tarde com alguns estudos, foi criado o registro.

De acordo com o IPHAN:

"O tombamento é um ato administrativo realizado pelo Poder Público com o objetivo de preservar, por intermédio da aplicação de legislação específica, bens de valor histórico, cultural, arquitetônico, ambiental e também de valor afetivo para a população, impedindo que venham a ser destruídos ou descaracterizados". (www.iphan.gov.br, acesso em: 11 abr. 2005)

O Instituto do Patrimônio Histórico e Artístico Nacional (IPHAN) inscreve o patrimônio material em um dos quatro livros do Tombo: Livro do Tombo Arqueológico, Etnográfico e Paisagístico; Livro do Tombo Histórico; Livro do Tombo das Belas Artes e o Livro das Artes Aplicadas.

Segundo o IPHAN ainda:

\begin{abstract}
Suas ações voltadas à identificação, documentação, restauração, conservação, preservação, fiscalização e difusão, estão calcadas em legislações específicas sobre cada um dos temas pertinentes ao seu universo de atuação. A conservação e a restauração são intervenções técnicas sobre um bem cultural. "Conservar consiste em manter o bem, seja ele um prédio, um quadro ou um livro raro, livre de qualquer dano. É uma medida preventiva para que não se chegue à restauração, que é a intervenção direta em uma peça danificada pelo tempo ou má conservação". (www.iphan.gov.br)
\end{abstract}

Em seu texto Londres ainda acha que não basta um bem ser tombado, ele precisa ser aceito ou absorvido pela sociedade como uma coisa valiosa que precisa ser preservada e pelo Estado com políticas adequadas e atualizadas de preservação do bem cultural. 
Londres (2001, p.192-193):

\begin{abstract}
Mesmo quando a iniciativa parte do Estado, esses valores precisam ser aceitos e constantemente reiterados pela sociedade, a partir de critérios que vão variar no tempo e no espaço. Ainda nessa linha de reflexão, fica claro que a elaboração e aplicação de instrumentos legais, como o tombamento, não são suficientes para assegurar que um bem venha a cumprir efetivamente sua função de patrimônio cultural junto a uma sociedade. É preciso que ocorra constante atualização das políticas específicas, tanto mais necessária, se essas políticas se desenvolvam num contexto democrático.
\end{abstract}

Portanto é necessária a conscientização de um povo ou comunidade e dos órgãos governamentais sobre a importância da conservação do patrimônio cultural, para que ele não necessite ser restaurado. Caso ele precise de restauro, que seja feito de uma maneira que vá conservar as origens do bem tombado. Só assim os valores serão repassados intactos às gerações futuras e com grandes significados, mantendo sua identidade original.

De acordo com Vianna (2004, p. 52):

Recentemente, no sentido de aperfeiçoar as formas de reconhecimento, salvaguarda, valorização e legislação de proteção, foi instituído, por decreto (3.551-4/8/00), o Registro de bens culturais de natureza imaterial e o Programa Nacional do Patrimônio imaterial que deve articular, fomentar e apoiar as políticas de estados e municípios para promover o reconhecimento e o registro, disponibilizar as informações, elaborar políticas públicas de valorização e de apoio à diversidade cultural.

O registro é um documento realizado pelo Poder Público com o intuito de reconhecer e assim preservar os bens imateriais, para que este conserve suas origens, história e seus valores. Podendo ser repassado ao longo dos tempos a outras pessoas.

Os bens selecionados para registro serão inscritos em livros denominados, respectivamente: Livro de registro de saberes (registro de conhecimentos e modos de fazer); Livro das celebrações (festas, rituais e os folguedos); Livro das formas 
de expressão (manifestações literárias, musicais, plásticas, cênicas e lúdicas) e Livro dos lugares (espaços onde acontecem práticas culturais coletivas).

Sant'anna (2003, p. 52) comenta:

O Instituto do Registro, criado pelo Decreto $3.551 / 2000$, não é um instrumento de tutela e acautelamento análogo ao tombamento, mais um recurso de reconhecimento e valorização do patrimônio imaterial. $\mathrm{O}$ registro corresponde à identificação e à produção de conhecimento sobre o bem cultural de natureza imaterial e equivale a documentar, pelos meios técnicos mais adequados, o passado e o presente dessas manifestações, em suas diferentes versões, tornando tais informações amplamente acessíveis ao público. O objetivo é manter o registro da memória desses bens culturais e de sua trajetória no tempo, porque só assim se pode "preservá-los".

O patrimônio cultural permite a determinados povos, uma sociedade, ou uma nação, o conhecimento de sua cultura, de suas tradições, ou seja, de sua história. E permite também, uma maior integração das diversas culturas. E com isso a valorização e preservação de sua riqueza cultural.

Como diz Oliven (2003, p. 77):

O patrimônio cultural precisa ser preservado, numa operação por meio da qual se procura guardar algo que corre o risco de ser destruído. Daí a idéia de que o patrimônio precisa ser mantido intacto, como se o tempo não passasse. Para preservar, precisamos, antes, classificar e colecionar. Por isso, temos agentes que detêm o poder legítimo de definir o que faz parte do patrimônio. Esses "guardiões do patrimônio" definem o que é digno de ser preservado. Esses bens, pelo seu caráter único e pelo fato de serem vistos como depositários de uma memória que aponta para a identidade nacional, precisam ser defendidos.

\subsection{Artesanato}

De acordo com pesquisas feitas pelos historiadores, o artesanato surgiu no período neolítico (6.000 a.C.), quando o homem aprendeu a polir a pedra, a fabricar a cerâmica como utensílio para armazenar e cozer alimentos e passou a utilizar as peles de animais e fibras vegetais para fazerem vestimentas. No Brasil, 
estudos revelam a fabricação de cerâmica por etnias do sudeste do Piauí a 6000 a.C. Portanto já temos desde está época uma definição simples de como o artesanato começou a ser produzido e veio ganhando espaço nos tempos atuais.

Beni (2001, p. 305-306) define artesanato como:

“Objetos produzidos manualmente ou com máquinas rudimentares, em pequena escala, que refletem a concepção especial e formal dos artistas populares de uma área, região ou país. As técnicas variam de acordo com a região e com a matériaprima utilizada".

Portanto, o artesanato é um conjunto de trabalhos manuais que requer criatividade e habilidade artística, utilizando-se de técnicas simples. São peças funcionais ou decorativas que simbolizam a cultura e a tradição de um povo.

De acordo com o SEBRAE Nacional (2004, p. 21): "Define-se como artesanato toda atividade produtiva que resulte em objetos e artefatos acabados, feitos manualmente ou com a utilização de meios tradicionais ou rudimentares, com habilidade, destreza, qualidade e criatividade".

Esse tipo de arte que não é somente popular, mas que tem vários elementos da arte clássica e que começou com o homem pré-histórico, modernizou-se através dos séculos, ganhou características regionais de cada indivíduo, grupo ou comunidade, e hoje é o artesanato que conhecemos, rico em variedades, formas, tendências e estilos.

Há um programa muito interessante de preservação dos artesãos na França, chamado Mestres da Arte e teve início em 1994. Este programa é muito importante para os Mestres de ofícios de arte, pois é uma forma de incentivo maior para que a tradição não se apague com o tempo, para que ela seja repassada à gerações futuras, preservando suas origens e sua identidade. 
Abreu (2004, p. 62) em seu texto comenta:

Este programa passou a integrar a Recomendação da UNESCO de salvaguarda do Patrimônio Imaterial ou Intangível e de valorização dos mestres de diferentes ofícios. De acordo com esta Recomendação, estes mestres seriam verdadeiros "tesouros humanos vivos", título do projeto da UNESCO para este setor. Os "Tesouros Humanos Vivos", segundo descrição da UNESCO, são "pessoas que encarnam no mais alto grau as competências necessárias ao andamento da vida cultural de um povo, enriquecendo o futuro da humanidade".

Abreu (2004, p. 63) ainda comenta:

O programa Mestres da Arte tem como objetivo o apoio a Mestres de ofícios de arte raros e excepcionais com uma longa tradição nacional e que por diversos motivos se encontrem em situação desfavorável economicamente. O suporte governamental resume-se a uma quantia mensal para a transmissão das habilidades e formação de discípulos. Mas não é atribuir a qualquer artesão a categoria de Mestre mas, sim, distinguir entre os Mestres de diferentes ofícios aqueles que, além de exercerem atividades raras e excepcionais no contexto das artes e ofícios tradicionais, por algum motivo necessitem do amparo do governo.

Este Programa desenvolvido na França é um incentivo aos órgãos públicos brasileiros a realizarem Programas ou Projetos que também preservem os artesãos, que são tão importantes para nossa cultura e história quanto os patrimônios material e imaterial do Brasil. $E$ com isso melhoraria também a qualidade de vida destes mesmos artesãos.

Existem alguns órgãos governamentais e programas que trabalham o artesanato e tentam preservar suas origens, dando suporte aos artesãos em sua divulgação e comercialização. São eles: Ministério do Desenvolvimento, Indústria e Comércio (MinDIC), com o Programa de Artesanato Brasileiro, tendo uma regional em cada estado; o Ministério do Turismo (MinTur); o SEBRAE Nacional, com o Programa SEBRAE de Artesanato; etc. Este último trabalha em parceria também com os 27 SEBRAE's regionais, um em cada estado. E por fim todos os órgãos trabalham em parceria para obterem um melhor resultado. Mas ainda é preciso mais iniciativa do governo em relação aos artesãos do país. 
Um outro caso interessante é o dos índios pataxós de Porto Seguro-BA. Com o passar dos anos foram surgindo dificuldades para esta tribo e nos anos 70, com a construção da rodovia BR-101, abre caminho para o turismo e assim a comercialização de artesanato feito por estes índios. O artesanato seria vendido a turistas e quem fosse por ali transitar. Os pataxós descobriram no artesanato uma fonte de renda para suas vidas.

Para Grunewald (2001, p. 140):

O caso do artesanato pataxó bem ilustra um processo de mercadorização de peças, como a gamela, que guarda continuidade de significado (e formatos) conforme às expectativas do mercado turístico e sem perda de autencidade. Portanto o que define a dinâmica cultural pataxó é justamente a constante renovação de seus elementos culturais em situações de interação social caracterizada pelo contato com o fluxo turístico.

O artesanato, portanto, construiu uma tradição para esta tribo, pois eles passaram a produzir peças artesanais e comercializá-las para sustentar suas famílias, atender o fluxo turístico da região e não mais para caráter utilitário. O artesanato passa a ser incrementado, inventado, mas continua sendo considerado autêntico e a tribo também não perdeu sua identidade, pois eles souberam definir o que faz parte de sua cultura e o que foi trazido pelos turistas.

Na mesma linha de pensamento o SEBRAE Nacional (2004, p. 68) diz:

Querer restringir o acesso do artesão às novas tecnologias (que são quaisquer ferramentas ou processos de produção e não apenas as de ponta, como se acredita erroneamente), não implica acabar com o artesanato autêntico, pois a autenticidade está na forma singular com que cada artista ou artesão vê o mundo ao seu redor e consegue representá-lo ou expressar seus sentimentos ou emoções. Uma nova ferramenta pode, no máximo, melhorar o desempenho da atividade realizada, facilitar a execução de uma tarefa, porém nunca fazer com que o homem mude sua forma de pensar. Contudo, a incorporação de uma nova ferramenta, de um novo modo de produzir, ou de um novo material, deve vir precedida de uma reflexão sobre os ganhos que esta mudança poderá trazer, sobretudo na melhoria real do resultado econômico. 
Compreende-se, portanto, que o artesanato para ser considerado autêntico tem que expressar os sentimentos de cada artesão e não como ele produz seu produto. Um novo instrumento de trabalho pode melhorar suas técnicas, aprimorar o design e não modificar a essência do seu produto.

No capítulo seguinte pode-se observar os principais tipos de artesanato, o que este ofício representa para os artesãos e os comentários dos órgãos públicos. 
Capítulo II: Reflexão sobre o artesanato local de Pirenópolis-GO

Neste capítulo a pesquisadora realizou uma análise descritiva sobre o artesanato local de Pirenópolis, verificou os principais tipos de artesanato existentes em Pirenópolis e compreendeu o significado do artesanato para os artesãos de Pirenópolis e para os órgãos públicos.

2. Descrição dos principais tipos de artesanato existentes em Pirenópolis

\subsection{Jóias de prata}

As jóias de prata tiveram sua origem com o ciclo do ouro em Pirenópolis. Em um primeiro momento houve ouriveres trabalhando o ouro que havia bastante na região e só depois, a partir dos anos 80 que vieram um grupo de "fora", normalmente hippies (argentinos, espanhóis, colombianos, uruguaianos, mineiros, paulistas, etc), que trouxeram as técnicas das jóias de prata e começaram a desenvolvê-la na região.

Os hippies chegaram na cidade e começaram a desenvolver o oficio das jóias de prata na região. Foram ensinando para os jovens a mecher com a prata e estes foram aprendendo e repassando para outras pessoas.

Pereira (2005) comenta:

Aprendi com os hippies que vieram de "fora" trazendo os seus conhecimentos, mas as técnicas foram desenvolvidas aqui em Pirenópolis, foram criadas pelos artesãos joalheiros da cidade e já faz parte da cultura e da identidade de nossa comunidade. Procuramos também passar para os nossos filhos, criando assim nossas próprias tradições. 
Em 84 o Sr. Pereira engajou neste grupo e começou a aprender as técnicas das jóias de prata. Mais tarde, se separou do grupo e montou seu próprio ateliê com mais 2 pessoas de Pirenópolis. Estes tinham mais experiência no ofício que Pereira. No decorrer dos anos com seus conhecimentos foi desenvolvendo suas próprias técnicas, criando seu estilo e acabou se separando de seus sócios. Hoje tem seu próprio ateliê e trabalha com sua esposa que também é artesã joalheira.

As jóias que fabrica são vendidas no seu próprio ateliê, passa para algumas pessoas em consignação e também comercializa nos finais de semana na Feira do Coreto, mais conhecida como Praça das Artes.

Segundo Pereira (2005): "Quando os hippis vieram para a cidade e começaram a desenvolver a prataria, não existia este fluxo turístico de hoje. De 10 a 15 anos pra cá que começou a ter lojas comercializando o artesanato".

Algumas pessoas da cidade na época em que os hippis vieram, não gostavam muito deles, pois tinham uma vida alternativa. Hoje muitos hippis são casados com pirenopolinos, tem filhos e seus próprios ateliês ou lojas de artesanato.

Os instrumentos utilizados para a produção de jóias são os seguintes: fundição, chapa, ilhotes, laminadora, fieira, alicate, tesoura, arco de cerra, a prata e pedras preciosas. O artesão pega a prata bruta (granulado) e fundi, faz ilhote, em seguida faz a chapa, depois passa pela laminadora e a fieira. Decidi se vai fazer um brinco, colar, etc. Dá o acabamento com o alicate, a tesoura, o arco de cerra e as pedras preciosas, que normalmente são ametista, turmalina, cristal, etc.

Pereira (2005) declara: "Tudo o que eu tenho veio do meu trabalho de artesão. Eu vivo da minha arte e consegui minhas coisas pessoais com este trabalho. Minha fonte de renda é toda do meu ofício como joalheiro". 
O Sr. Pereira é cadastrado em uma Associação, a Associação de Joalheiros e Artesãos de Pirenópolis (AJAP) e o motivo pelo qual se cadastrou é que a Associação ajuda os artesãos na divulgação de seus artesanatos e também quando tem feiras em outras cidades ou estados, os artesãos cadastrados tem preferência e são chamados a exporem seus produtos.

De acordo com o Sr. Pereira as maiores dificuldades que ele enfrenta com o seu artesanato é na divulgação. A divulgação deveria ser feita pela Prefeitura local e também pela Secretaria de Turismo, com isso os artesãos teriam uma maior facilidade em se conseguir a prata. A prata é trazida de São Paulo, Minas Gerais e Goiânia.

Pereira (2005) comenta:

“Deveria haver uma maior divulgação dos artesãos, ou seja, uma parceria da Prefeitura de Pirenópolis com o Governo do Estado de Goiás. Poderia ter também um guia dos artesãos locais, isso ajudaria os turistas a encontrar os artesanatos de suas preferências".

No guia dos artesãos teriam o endereço do ateliê ou da loja de artesanato, com os respectivos nomes dos artesãos e seus telefones. Isso facilitaria a comercialização do artesanato e até aumentaria a produção.

Pereira (2005): diz: "Pirenópolis é um dos maiores pólos de jóias de prata do Brasil e existe hoje na cidade cerca de 200 artesãos trabalhando. E a prataria foi um dos artesanatos que mais gerou emprego na cidade".

O artesanato contribuiu e ainda contribui para a geração de empregos, o crescimento e desenvolvimento da cidade e o aumento do turismo. Turismo este que é bem vindo, de acordo com a opinião de Pereira. 
Conforme Pereira (2005):

"O artesanato tem atraído milhares de turistas nos meses de Janeiro; Maio, quando acontece as Cavalhadas; Julho e Dezembro; nos finais de semana e feriados. Foi por meio do artesanato que os turistas começaram a ir para a cidade e esta passou a ser conhecida".

A cidade passou a ser conhecida também pelas belezas naturais e pela divulgação boca-a-boca das pessoas que a visitavam, e que vinham em busca de paz e tranqüilidade.

$\mathrm{Na}$ página seguinte seguem-se as fotos de algumas peças produzidas pelo Sr. Pereira, que são: anéis, colares e brincos. 
Figura 1: Colares e anéis de prata

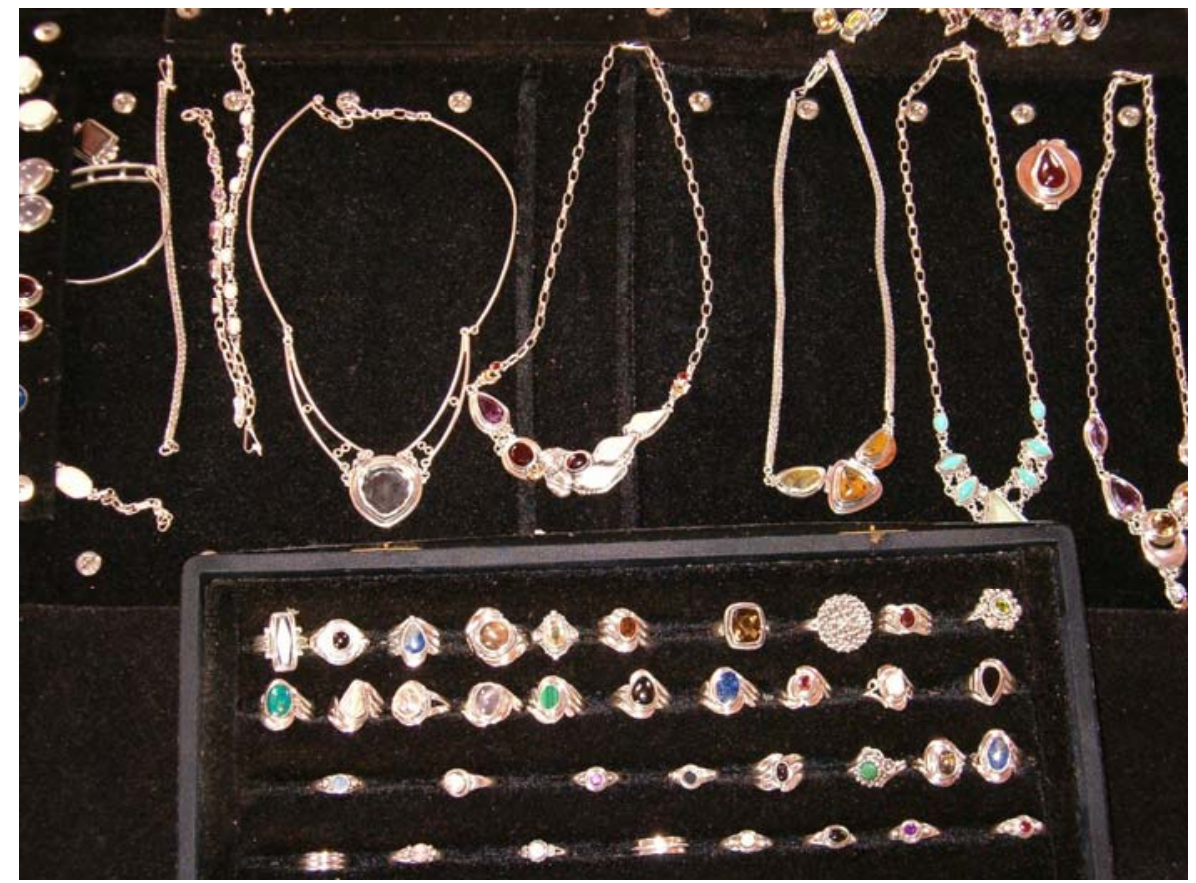

Fonte: Rodrigues, Ludmilla. Pirenópolis. 29 de Março de 2005

Figura 2: Anéis de prata

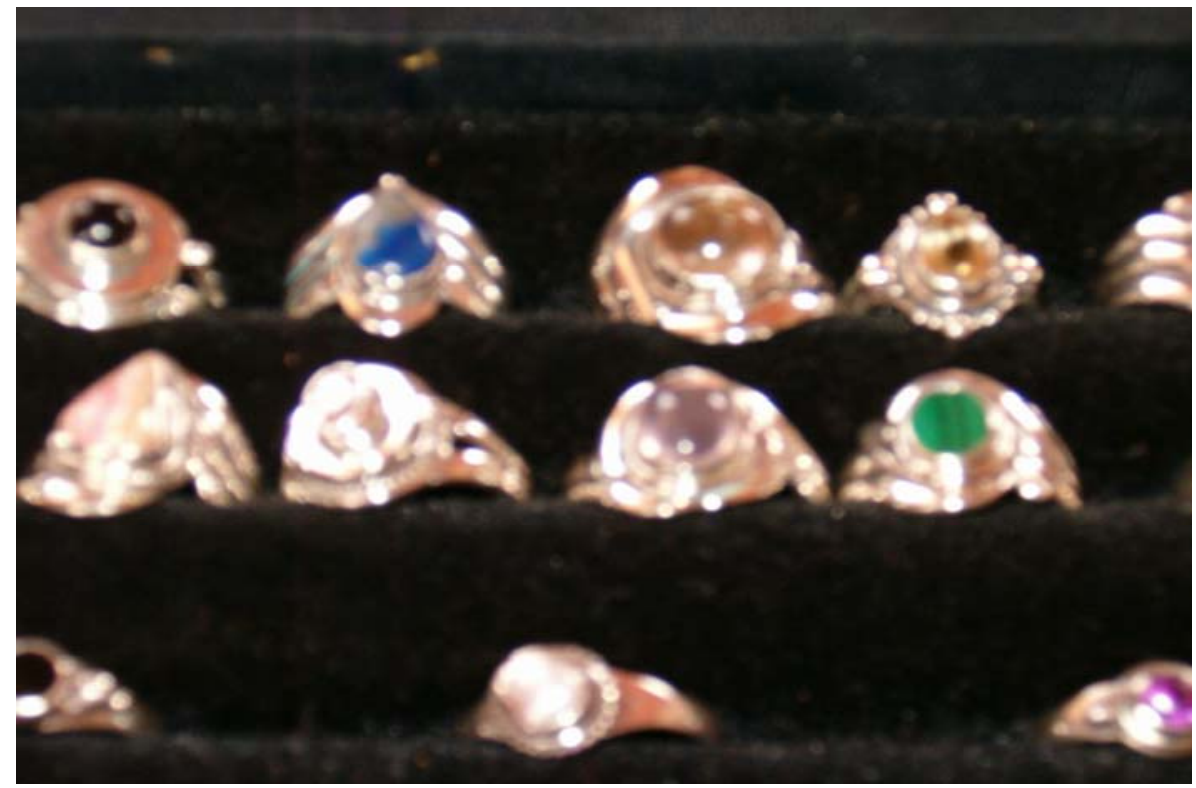

Fonte: Rodrigues, Ludmilla. Pirenópolis. 29 de Março de 2005 
2.2 Escultura em pedra

O artesanato em pedra veio de São Tomé das Letras - MG e foi trazido para Pirenópolis por "Maneco" a mais ou menos 10 anos. Este cortava as pedras, esculpia fazendo vários objetos e comercializava. Hoje ele não trabalha mais com este tipo de artesanato.

No começo o Sr. Pinto via as peças produzidas por Maneco e como ele as cortava. Aos poucos foi aprendendo a cortar suas pedras e aprimorando suas técnicas. Hoje usa muita criatividade para esculpir as peças. Procura fazer paisagens, fachadas das igrejas de Pirenópolis, principalmente da Matriz, que é patrimônio da cidade e referência para vários turistas.

Pinto (2005) diz: "No começo fazia umas peças feias. Levava para expor em Goiânia e nem tinha lugar direito para colocá-las. O povo olhava e nem fazia questão de comprar".

A escultura em pedra é feita usando-se os seguintes materiais: pedra (quartzito), cola, bucha vegetal, tinta guache e chapinha de ferro para cortar a pedra. $O$ artesão corta a pedra e monta as peças, depois pinta e faz os detalhes, dando o acabamento final.

O escultor busca estas pedras (o quartzito) nas Pedreiras de Pirenópolis. As Pedreiras é bem conhecida em Pirenópolis e muitos outros artesãos a utilizam para fazerem seus artesanatos em pedra.

Segundo Pinto (2005): "O meu artesanato é todo feito manualmente, não utilizo nenhuma máquina, pois acho mais fácil, rápido e também prazeroso fazer a mão". O Sr. Pinto trabalha com este ofício a 5 anos e produz uma média de 300 peças pequenas e cerca de 200 peças grandes. Totalizando 500 peças por mês. 
Pinto (2005) comenta: "O artesanato é minha vida, e as esculturas em pedra surgiram da necessidade de se ter um trabalho, é de onde eu tiro o meu sustento e o da minha família".

O escultor também comenta que suas esculturas já fazem parte da cultura dos pirenopolinos, pois estes valorizam e admiram o seu trabalho. Já os turistas vão à cidade e acabam comprando seu artesanato, pois acham que ele é bem representativo da identidade local.

Pinto (2005) declara: "Os turistas preferem as esculturas pequenas, ou seja, as miniaturas das casinhas de Pirenópolis, as miniaturas das fachadas das igrejas, das paisagens, etc".

O artesão fabrica seu artesanato em casa, mas costuma comercializar e divulgar suas esculturas na Feira das Artes, fornece algumas peças para as lojas de artesanato da cidade, para lojas de artesanato na Cidade de Goiás e aceita encomendas.

O Sr. Pinto não é cadastrado na Associação de Joalheiros e Artesãos de Pirenópolis (AJAP). No seu caso ele não acha o cadastro importante, pois já comercializa o seu artesanato em vários lugares.

De acordo com Pinto as maiores dificuldades que tem enfrentado é a questão da divulgação de seus produtos feitos em Pirenópolis. Ele acha que a prefeitura local e a Secretaria de Turismo deveriam dar mais apoio aos artesãos.

Pinto (2005) afirma: "Apesar da pouca divulgação do artesanato de Pirenópolis, este tem proporcionado para a cidade crescimento e melhoria na qualidade de vida dos artesãos. Pois os artesãos encontram neste ofício um meio de sustentarem suas famílias". 
$\mathrm{O}$ artesanato também tem contribuído muito para o aumento do turismo na cidade e para a divulgação das belezas naturais da mesma. $E$ conseqüentemente 0 turismo aumentando, surgem novos artesãos a cada dia e pessoas de outros estados e até países. Estas pessoas vão à passeio e acabam se apaixonando pela tranqüilidade da cidade e pela riqueza de sua cultura.

Conforme Pinto (2005): "O aumento do turismo proporciona o aumento da produção artesanal, ou seja, os artesãos locais passam a vender muito mais para atender as exigências dos turistas".

$\mathrm{Na}$ página seguinte seguem-se as fotos de algumas peças produzidas pelo Sr. Pinto, que são: casinhas e quadros em pedra (quartzito). 
Figura 3: Casinhas e quadros em pedra

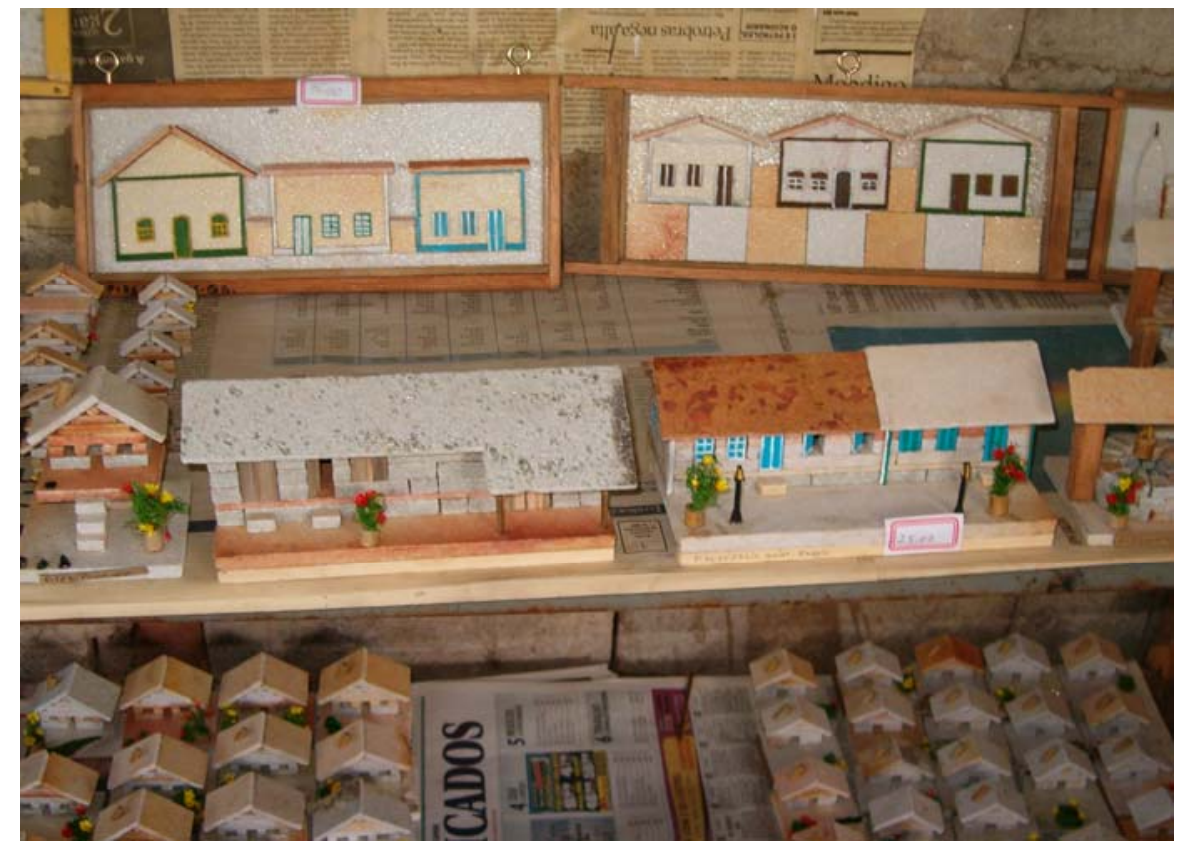

Fonte: Rodrigues, Ludmilla. Pirenópolis. 29 de Março de 2005

Figura 4: Casinhas em pedra

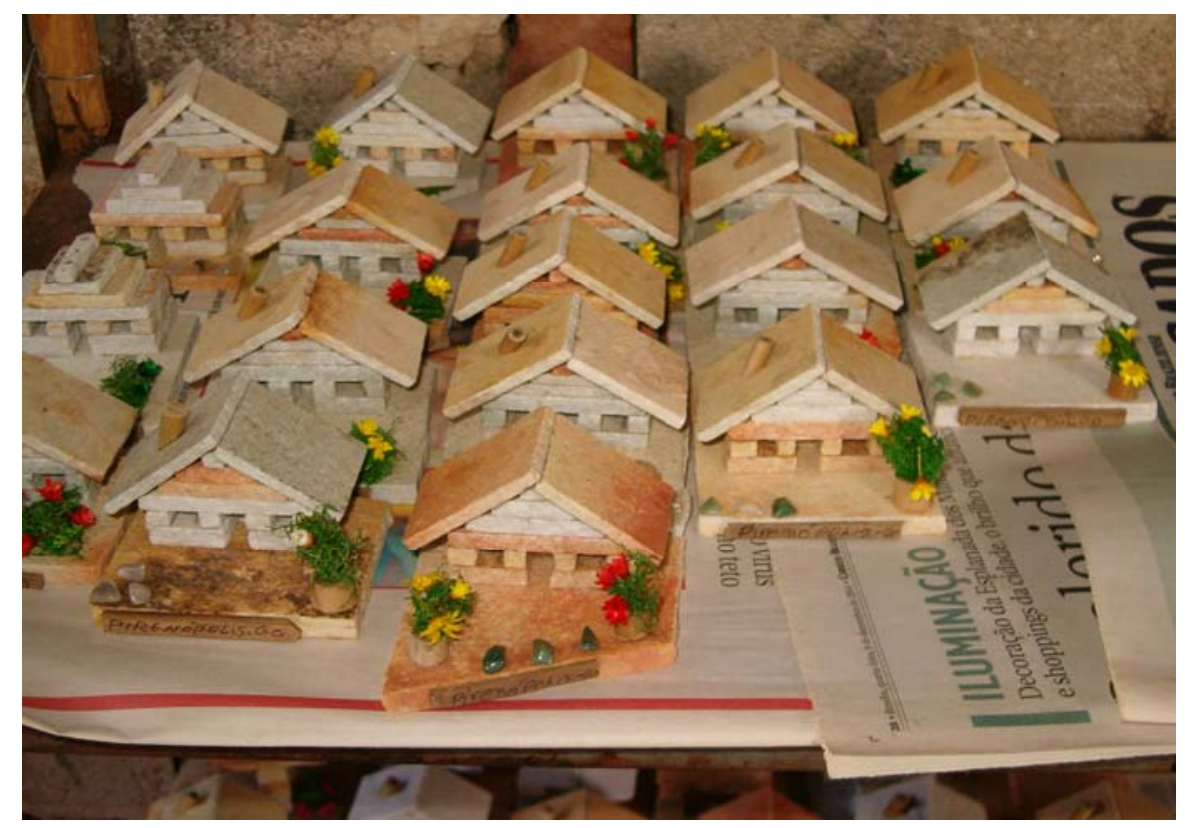

Fonte: Rodrigues, Ludmilla. Pirenópolis. 29 de Março de 2005 
2.3 Patchwork (Tapetes e colchas de retalho)

Patchwork é a arte de emendar retalhos e consiste em unir retalhos de um mesmo tecido, formando combinações de cores e desenhos. Para o arremate dos trabalhos de patchwork, utiliza-se pesponto largo, mais conhecido como quilt. $\mathrm{O}$ quilt é uma espécie de alinhavo, usado para criar efeitos de relevo nos trabalhos de patchwork. O quilt pode ser feito à mão ou com a máquina de costura.

Este artesanato é um dos mais antigos em Pirenópolis e é passado de geração a geração. Antes era feito só pra uso de casa e como encomenda para enxovais de noiva. Com o passar dos anos aprimorou-se a técnica e hoje é confeccionado para comercialização.

De acordo com Silva (2005):

Eu aprendi a arte de se fazer colchas e tapetes de retalhos com minha mãe, mas era uma coisa rústica, e fui aprimorando e dando um acabamento melhor. E ela aprendeu com minha avó e assim por diante. Procurei ensinar meus filhos e passar as técnicas, mas nenhum deles tiveram interesse. Minha neta de 8 anos tem interesse, mas ainda não tem idade.

As colchas e os tapetes de retalho são o meio pela qual a artesã trabalha e ganha dinheiro. É um serviço que ajuda no complemento de sua família. E ela considera este artesanato como patrimônio e tradição da cidade, pois existe há muitos anos e vem sendo passado de geração a geração, sendo aprimorado, mas ainda preservando suas características originais. Hoje as pessoas encomendam, não mais para enxovais e sim para usarem em suas casas no dia-a-dia.

Silva (2005) comenta:

Eu trabalho com este artesanato há 15 anos e é dele que tiro o meu sustento, a minha renda. A arte de se fazer colchas e tapetes é da própria cidade e da cultura do povo. Alguns anos atrás a saída de colchas era melhor, pois antes havia poucas pessoas na região que faziam este artesanato e hoje como há muitas pessoas fazendo colchas e tapetes a produção diminuiu um pouco. Quando eu comecei vendia bem melhor e mais caro e hoje vendo menos e mais barato. 
Os materiais usados para a confecção dos tapetes e colchas de retalhos são: máquina de costura, tesoura, linha, agulha, retalhos de tecidos, normalmente de algodão. A artesã corta os retalhos, "joga" com as cores e depois vai emendando um por um, formando quadros os mais diferentes e criativos possíveis. Estes materiais são comprados em Anápolis.

A artesã produz e comercializa suas colchas e tapetes de retalho em sua própria casa e aceita encomendas de Brasília, Goiânia, São Paulo, etc. Antes vendia na Feira das Artes, mas não obteve muito retorno. Ela tem planos de abrir uma loja, mas por enquanto ainda não decidiu.

A Sra. Silva não é cadastrada na Associação de Joalheiros e Artesãos de Pirenópolis (AJAP). Ela não teve interesse em se cadastrar por achar sua clientela muito boa e diz que pode conseguir suas coisas sem a ajuda da Associação.

Silva (2005) diz:

"Por causa do aumento do turismo muitas pessoas passaram a fabricar e comercializar colchas e tapetes de retalhos. Descobriram este artesanato como fonte de renda para suas vidas. O turismo influencia na medida em que aumenta a produção artesanal na cidade e surgem novos artesãos".

E uma das maiores dificuldades enfrentadas por Silva é o fato de seu artesanato não ser divulgado. Ela acredita que deveria ter maior incentivo por parte da prefeitura, mas como o prefeito é recente no cargo, ainda não teve tempo de demonstrar seu trabalho.

Mas de uma maneira geral a artesã acredita que o artesanato proporcionou melhoria de vida à comunidade local e geração de empregos na cidade.

$\mathrm{Na}$ página seguinte segue-se as fotos de algumas peças produzidas pela $\mathrm{Sr}^{\mathrm{a}}$. Silva, que são: colchas e tapetes de retalho. 
Figura 5: Tapete de retalho

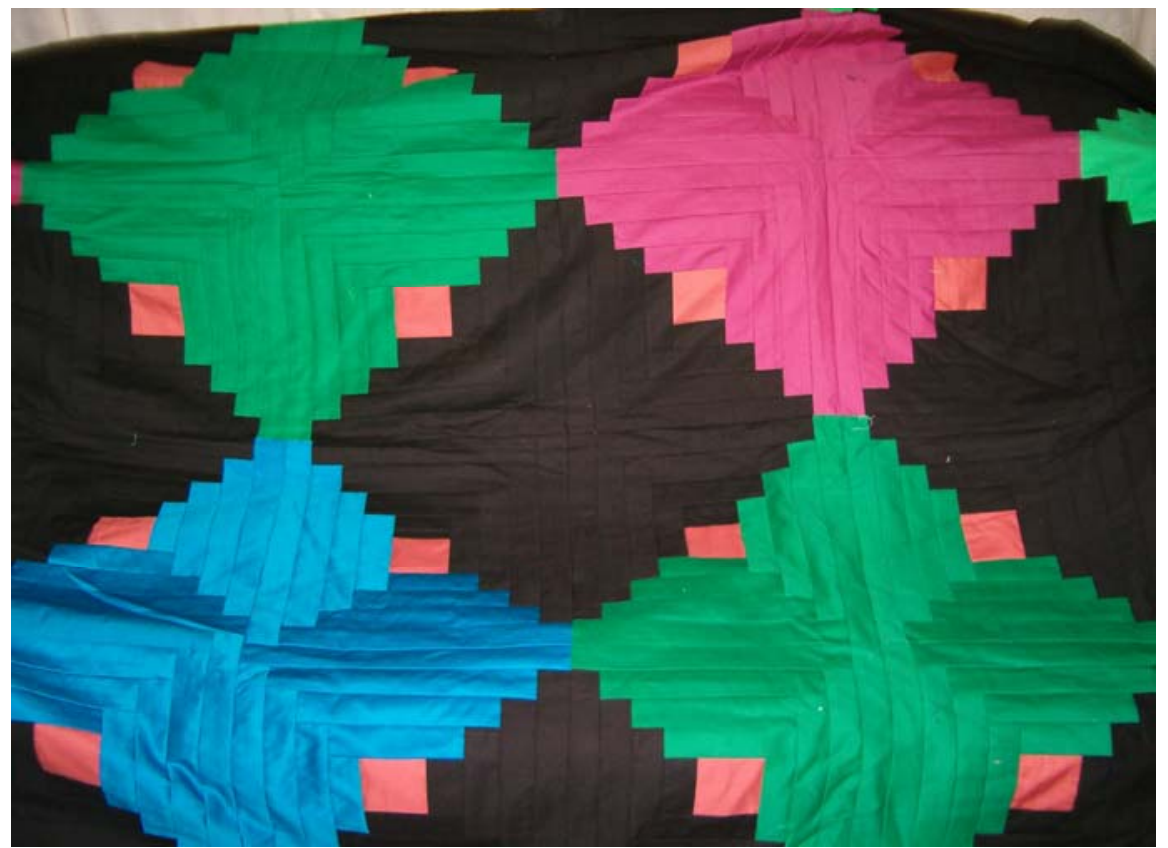

Fonte: Rodrigues, Ludmilla. Pirenópolis. 29 de Março de 2005

\section{Figura 6: Colcha de retalho}

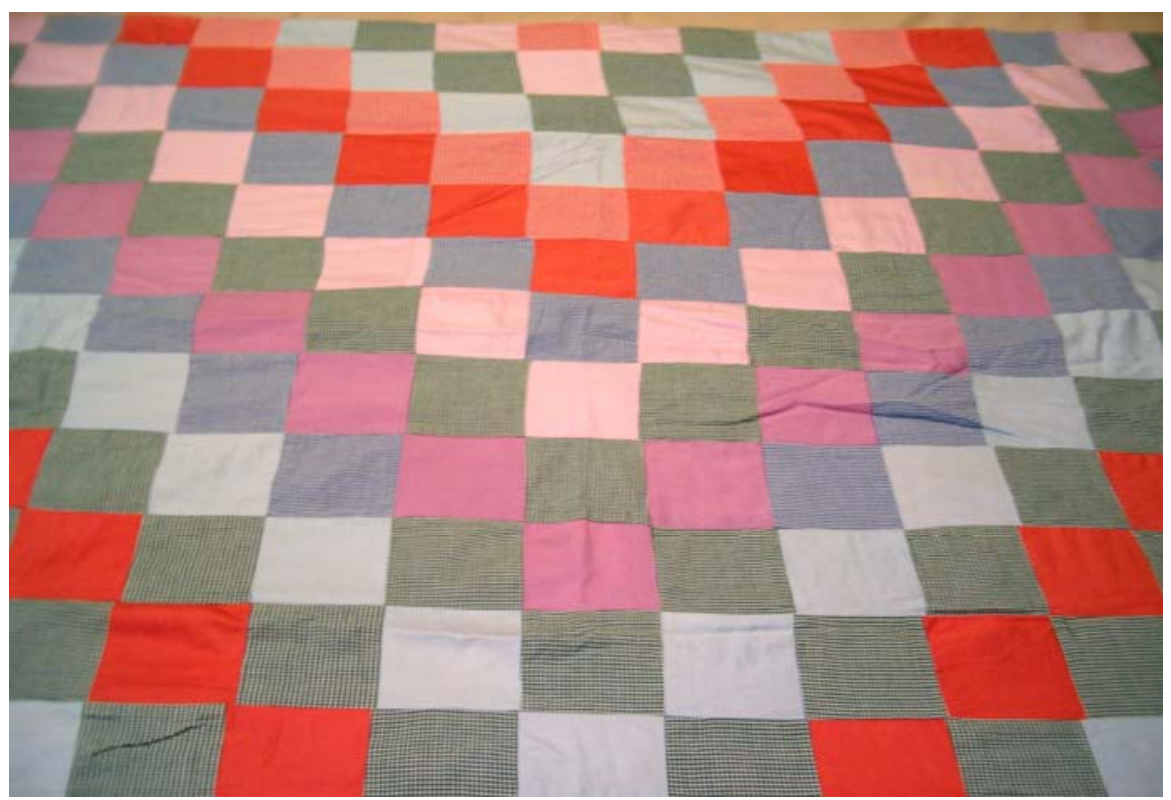

Fonte: Rodrigues, Ludmilla. Pirenópolis. 29 de Março de 2005 


\subsection{Tecelagem}

A arte da tecelagem artesanal consiste, apenas, em entrelaçar fios de uma única cor ou de várias cores, com a ajuda de um tear. O tear é uma ferramenta simples, que permite o entrelaçamento de uma maneira ordenada de dois conjuntos de fios, denominados trama e urdidura, formando como resultado uma malha denominada tecido.

A técnica da tecelagem foi desenvolvida há muito tempo, quando os homens préhistóricos começaram a produzir suas próprias vestimentas.

Os materiais utilizados na confecção dos tecidos são: fios de várias cores, malhas, fibras têxteis, o tear. A artesã coloca os fios no tear e começa a tecer, até formar um tecido bem consistente, daí ela faz bolsas, tapetes, almofadas, jogos americanos, roupas, etc.

Conforme Monteiro (2005):

"A tecelagem é o meu trabalho, é onde encontro forças para viver e enfrentar os problemas do dia-a-dia, é onde ganho dinheiro para manter minha casa e dar boa educação às minhas filhas. Também considerado este ofício um elemento central na formação da cultura do povo de Pirenópolis".

O ofício de tecer fios foi aprendido por Monteiro com uma amiga que dava aulas em um curso em São Paulo. E há 13 anos veio para Pirenópolis e começou a desenvolver as técnicas deste artesanato. Já existia na cidade pessoas que trabalhavam com o tear, ela apenas passou seus conhecimentos para outras pessoas, que estavam interessadas nesta arte. 
Monteiro (2005) considera: "Pirenópolis já tinha a tradição da tecelagem, só incorporei meus conhecimentos, minhas técnicas à linguagem da cidade. $E$ acabei aprendendo outras técnicas com a comunidade local que também sabia a arte de tecer com fios".

Portanto a tradição da tecelagem já existia na cidade bem antes desta tecelã ir para lá. Vem de longos anos, quando os pais passavam para seus filhos. Ela apenas passou um pouco do que sabia para as pessoas de Pirenópolis e também aprendeu com elas.

Monteiro (2005) declara: "Ensinei para algumas pessoas de Pirenópolis que trabalham hoje na minha loja, a arte de tecer e "jogar" com as cores e procuro passar para minhas filhas, que são nascidas em Pirenópolis e trabalham comigo também".

A Sr. ${ }^{a}$ Monteiro tece os fios nos teares e comercializa seu artesanato em sua própria loja, em feiras de São Paulo e Brasília e aceita encomendas. A loja tem no total 5 teares e 10 funcionários trabalhando. Estes trabalham tanto na venda como na tecelagem de fios.

A artesã é cadastrada na Associação e seu interesse em se cadastrar foi pela divulgação que esta pode proporcionar de sua loja e de seus produtos.

Segundo Monteiro (2005):

"O turismo contribuiu para o aumento da produção artesanal de minha loja e com o decorrer dos anos a loja teve que ser ampliada para atender toda a clientela. Eu também comecei a aceitar encomendas e mandar para outros estados, como: São Paulo, Brasília, Minas Gerais, etc". 
Uma das dificuldades destacadas pela artesã é a produção de artesanato idêntica um dos outros. No caso da tecelagem, Monteiro acha que tem muitos produtos iguais sendo comercializados e sem criatividade.

Monteiro (2005) comenta:

"Tem muitos produtos iguais sendo vendidos, então as pessoas deveriam ter mais informação da cultura local, para terem criatividade e produzirem produtos inovadores e que atraiam os turistas. Os artesãos precisam de mais informações do que está sendo feito, procurando criar e desenvolver coisas diferentes".

A artesã acredita que para melhorar o artesanato comercializado em Pirenópolis a Prefeitura ou a Secretaria de Turismo deveria fazer um centro de informações para o artesão. Este local teria informações sobre a cultura local, o que está sendo produzido pelos artesãos, livros, revistas e pessoas falando sobre assunto.

A artesã ainda comenta que a transmissão da cultura, a troca de idéias e a troca de informações fazem com que os produtos, ou seja, o artesanato enriqueça, sem perder sua autenticidade.

$\mathrm{Na}$ página seguinte seguem-se as fotos de algumas peças produzidas pela $\mathrm{Sr}^{\mathrm{a}}$. Monteiro, que são: bolsas, faixas de cabelo, tapete e o tear, utilizado para a fabricação destes artesanatos. 
Figura 7: Bolsa, tapete e faixa de cabelo

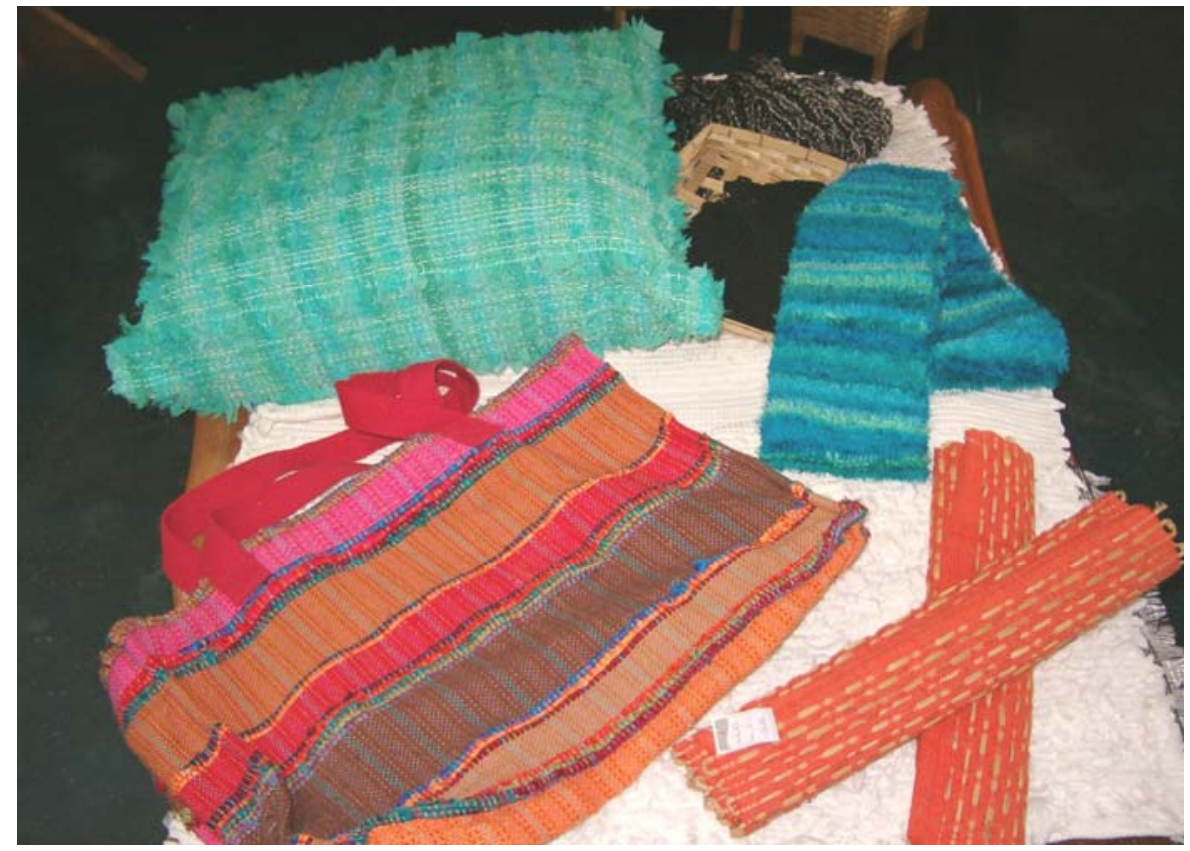

Fonte: Rodrigues, Ludmilla. Pirenópolis. 29 de Março de 2005

Figura 8: Tear

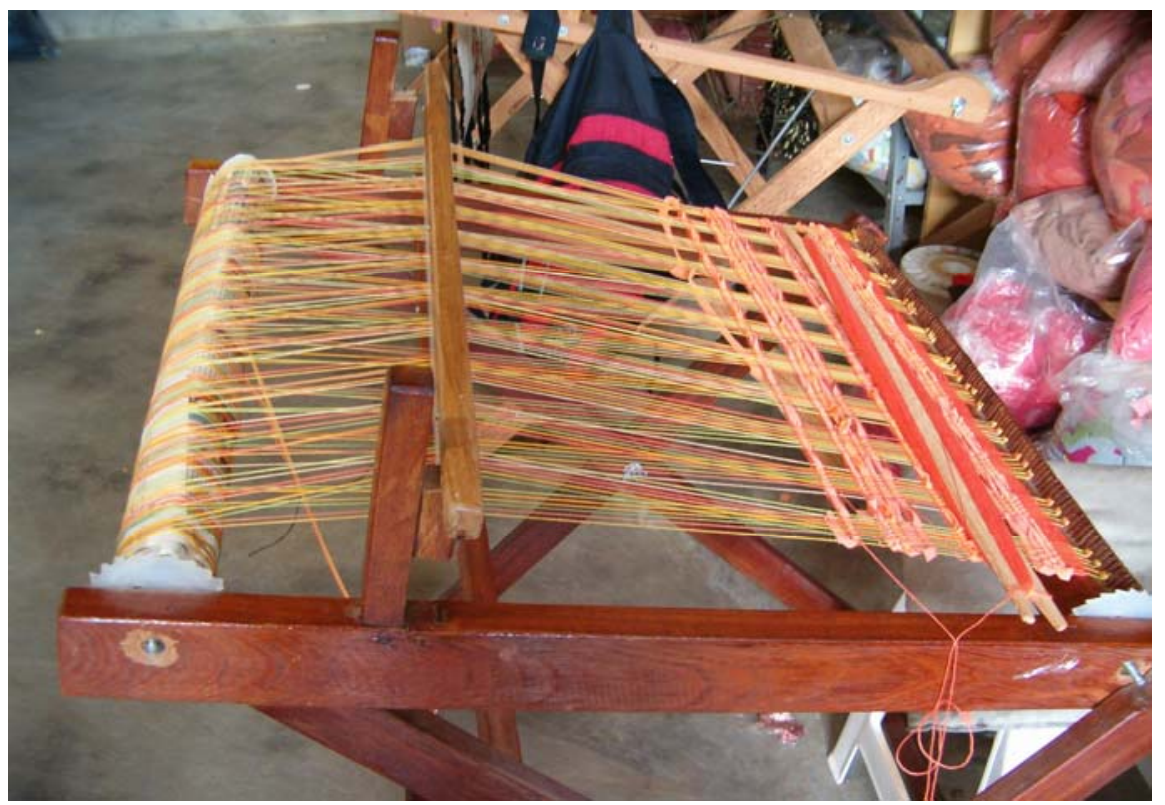

Fonte: Rodrigues, Ludmilla. Pirenópolis. 29 de Março de 2005 
2.5 Máscara de papel

A máscara de papel teve sua origem em Portugal e não se sabe ao certo a data. Em Pirenópolis foi usada pela primeira vez por um mascarado durante a Semana Santa. Na época da Semana Santa também acontece a Festa do Divino e as Cavalhadas, que é a representação simbólica da história de luta travada entre o Imperador do ocidente, Carlos Magno e os cristãos. A encenação ocorre durante os meses de maio ou junho, normalmente 50 dias após a ressurreição de Cristo

De acordo com Pina (2005):

\begin{abstract}
As máscaras, juntamente com as Cavalhadas representam uma tradição para a cidade e a comunidade local, pois faz parte da Festa do Divino e é realizada a mais de um século. A festa acontece desde 1819 quando foi trazida para Pirenópolis e hoje faz parte da cultura de nosso povo. O povo da cidade tem muito orgulho desta festa e ela é comemorada com muito entusiasmo e alegria.
\end{abstract}

Já a máscara de papel teve sua origem um século depois da chegada da Festa do Divino em Pirenópolis, em 1826, mas não se sabe precisar a data certa que ela surgiu. A arte foi sendo passada de geração a geração e hoje é usada pelos famosos mascarados. Os mascarados usam roupas coloridas e máscaras enfeitadas, mais comumente com cara de boi ou diabo. Mas pode ter outras caras também. Eles saem a noite na época da Semana Santa fazendo algazarras e dançando pelas ruas da cidade.

Segundo Pina (2005): “As caras das máscaras normalmente são de bois ou diabo e tem gente que fala que é por influência da pecuária, que é muito conhecida e famosa no Estado de Goiás, mas não sei dizer se é verdade".

O artesão aprendeu a fazer as máscaras de papel com seu vizinho e as técnicas foram aprendidas com o filho deste mesmo vizinho. Ele faz máscaras há 45 anos e aprendeu quando tinha 12 anos de idade. Suas máscaras eram feitas no início 
em uma forma velha e meio quebrada. Com o passar dos anos foi desenvolvendo e aprimorando suas técnicas.

O material usado na confecção das máscaras é bastante simples: água e papel para fazer a massa da máscara, tintas guache, cola caseira, o molde da máscara (normalmente de argila ou pedra sabão) e verniz. Para fazer a massa da máscara, o papel é colocado na água por algumas horas, depois é colocado no liquidificador e triturado até obter uma consistência de polpa. Retira-se a massa do liquidificador deixe-a em repouso na peneira para escorrer o excesso de água. Em seguida modele a massa no molde e deixe-a secar por um tempo, só depois pinta com a tinta guache.

Pina (2005) comenta:

Como as máscaras já fazem parte das tradições da cidade, de nossa identidade, eu procurei passar para meus filhos, mas estes não tiveram muito interesse. Mas ensino outras pessoas e estou sempre envolvido na confecção das máscaras. Fabricar máscaras é minha vida, é onde encontro tranqüilidade pra resolver meus problemas. Eu até já fui um mascarado, mas hoje só participo mesmo da organização.

O artesão ainda comenta que as pessoas mais jovens não têm muito interesse em aprender e desenvolver as técnicas deste artesanato e acabam se esquecendo do verdadeiro sentido da Semana Santa.

Pina (2005) diz:

"O pessoal mais jovem esquece dos princípios ou do valor religioso da festa do Divino. Hoje os jovens querem é ficar bonitos, aparecer com suas máscaras e roupas coloridas. Perde um pouco daquela fantasia de antigamente, quando as pessoas ficavam dias preparando a festa". 
O que ele tem feito para ajudar na preservação desta tradição e fazer com que os mais jovens se interessem pela festa, são As Cavalhadinhas, realizadas sempre 15 dias após as Cavalhadas. Por isso ele também ajuda em sua organização e procura ensinar as crianças e os jovens como fazer as máscaras. Mas ele acha que as escolas de Pirenópolis por meio da educação poderiam ajudar também na preservação da festa e das máscaras.

O artesão confecciona as máscaras de papel sob encomendas. As encomendas normalmente são feitas para feiras e exposições em Brasília, São Paulo, etc. Hoje em dia prefere fazer as miniaturas que servem de enfeite e decoração para a casa também.

O Sr. Pina não é cadastrado na Associação, pois como trabalha apenas com encomenda de máscaras e ajuda na organização das Cavalhadas não vê necessidade deste cadastramento.

De acordo com Pina (2005):

"A produção artesanal tem aumentado muito o turismo na região e as máscaras têm contribuído muito para isso, pois as pessoas vão assistir As cavalhadas e os Mascarados e acabam comprando as miniaturas das máscaras para levarem de lembranças para suas casas".

O Sr. Pina comenta também que o turismo proporcionou melhoria de vida e trabalho para muitas pessoas de Pirenópolis. E diz ainda que a cada dia são abertas mais lojas de artesanato na cidade.

$\mathrm{Na}$ página seguinte seguem-se as fotos de algumas peças produzidas pela Sr. Pina, que são: máscaras de papel com rostos de boi, diabo, etc. 
Figura 9: Máscaras de papel

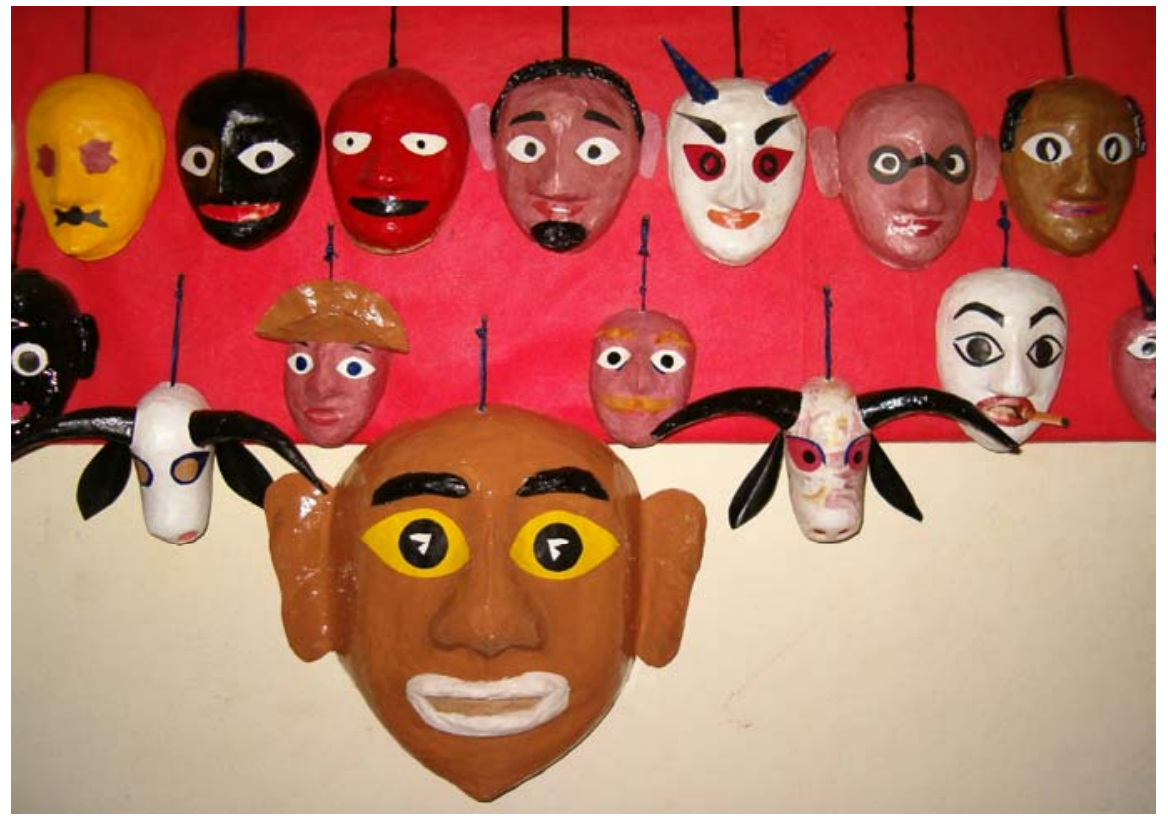

Fonte: Rodrigues, Ludmilla. Pirenópolis. 30 de Março de 2005

Figura 10: Máscaras de papel

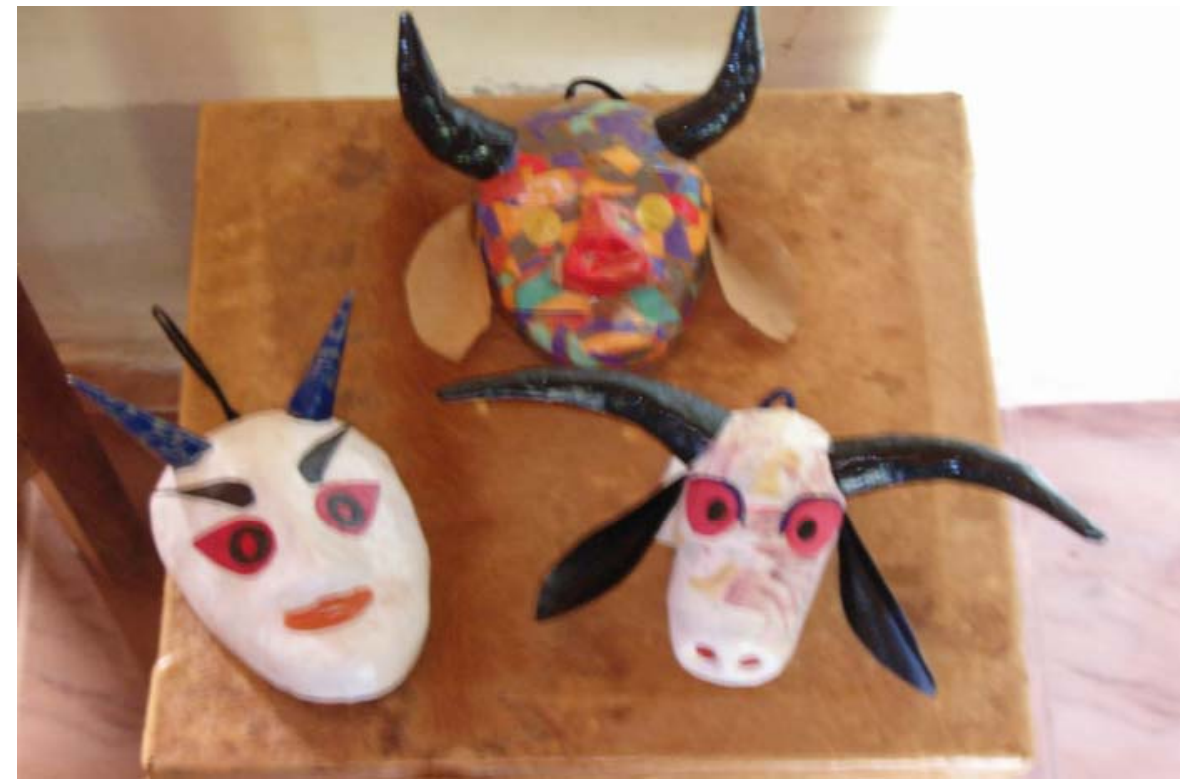

Fonte: Rodrigues, Ludmilla. Pirenópolis. 30 de Março de 2005 


\subsection{Cerâmica}

A cerâmica tem sua origem há muitos séculos atrás, quando o homem préhistórico verificou a necessidade de armazenar os alimentos colhidos na natureza.

Entende-se por cerâmica a todos os objetos produzidos com argila e assados em temperaturas elevadas em fornos adequados. A transformação do barro em cerâmica acontece durante a queima.

Os materiais utilizados para a produção de cerâmica são os seguintes: argila, água e em algumas peças tinta. Em um primeiro momento pega-se a argila e molda conforme o seu interesse. Em seguida, a peça é guardada por alguns dias para secar. Depois lixa-se a peça e coloca no forno para a primeira queima. A primeira queima dura um dia, depende da peça produzida. A coloração e a textura final será dada na segunda queima, que pode durar um dia e meio ou dois.

Quanto à argila, ela é comprada em Anápolis, São Paulo e Jaraguá ou pega-se de um barreiro em Pirenópolis. Mas ela prefere comprar já preparada, ou seja pronta para moldar, livre dos corpos indesejáveis e das impurezas orgânicas. Normalmente utiliza o barro ou argila branca e vermelha.

Abreu (2005) afirma: "A cerâmica representa a minha vida, o meu sustento, faz parte da tradição e da cultura local. É o artesanato mais antigo da humanidade e vem desde a pré-história, quando os homens das cavernas guardavam seus alimentos".

A artesã ainda diz que adquiriu um pouco dos seus conhecimentos com a família Filo Gomes, bem tradicional em Pirenópolis. Ela estudou e aprendeu as técnicas deste artesanato com a $D^{a}$. Luzia Filo Gomes (falecida), uma ceramista bem conhecida e respeitada na cidade e também aprendeu algumas coisas com $D^{\mathrm{a}}$. 
Safia. Mas com o passar dos anos ela foi aprimorando suas técnicas e trabalha há 20 anos com este ofício.

Abreu (2005) comenta: "Eu gosto de aprender, de relacionar com o pessoal que meche com artesanato e por isso procurei a cerâmica. Eu me identifiquei muito com as pessoas que faziam".

As peças que a artesã faz estão sempre ligadas com a cultura local, com o dia-adia da comunidade e as festas, principalmente as Cavalhadas. As cerâmicas que mas produz são os cavalinhos das Cavalhadas, máscaras e vasilhas utilitárias para a culinária típica do Estado.

De acordo com Abreu (2005):

“As peças que produzo são vendidas em minha própria casa, na Feira das Artes, na Piretur, que é uma loja ligada à Secretaria de Turismo para a comercialização do artesanato, e também sob encomenda. Eu recebo encomendas de todos os lugares do país: Recife, Brasília, Goiânia, São Paulo, etc".

A artesã não é cadastrada na Associação e não tem interesse em se cadastrar, pois ela diz que sua divulgação já é boa, e tem muitas propostas para expor seu artesanato.

Quanto ao turismo ela acredita que tem melhorado e muito a venda do artesanato e o aumento da produção. E com isso gerado emprego na cidade.

Abreu (2005) diz: "Com o aumento do turismo e a venda de artesanato na cidade as pessoas tem passado menos dificuldades e até melhorado a qualidade de vida". 
Uma dificuldade que a artesã enfrenta é o de encontrar a argila na cidade, e quando encontra, esta não pode ser mechida, pois a cidade tem várias áreas de preservação ambiental. Outra dificuldade que ela vê é como arrumar uma pessoa para pegar este barro e levar para os ceramistas.

Abreu (2005) comenta: "A prefeitura local deveria ajudar mais os artesãos, disponibilizando uma pessoa para buscar o barro ou a argila no barreiro e levar para os ceramistas trabalharem".

A artesã procura passar seus conhecimentos e suas técnicas da cerâmica para os filhos mas estes não têm muito interesse. No geral ela acredita que os jovens de hoje não querem saber muito desta arte, eles acham o barro pesado. Por isso ela acha que a prefeitura poderia ajudar com cursos e oficinas de cerâmica para despertar o interesse dos jovens e crianças.

A ceramista diz que existe em Pirenópolis uma ONG que trabalha com a conscientização dos jovens e crianças acerca da cerâmica. Esta ONG existe há 5 anos e é uma Associação totalmente independente do governo e da prefeitura local.

De acordo com Abreu (2005) "A COEPI é uma Associação sem fins lucrativos que desenvolve atividades educacionais e culturais complementares ao ensino formal, visando a ocupação e a capacitação de crianças, adolescentes e adultos da comunidade local".

A COEPI trabalha com oficinas de barro desde o início de 2004, com o objetivo de resgatar nas crianças e jovens o interesse pela cerâmica e aprimorar as técnicas. As peças que são mais produzidas nestas oficinas são as máscaras e as fachadas das igrejas de Pirenópolis. 
Mas mesmo assim ela acredita que faltam iniciativas da Prefeitura local e da Secretaria de Turismo de Pirenópolis e que eles trabalhando juntos podem fazer muito mais para reverter a situação da cerâmica na cidade.

$\mathrm{Na}$ página seguinte seguem-se as fotos de algumas peças produzidas pela $\mathrm{Sr}^{\mathrm{a}}$. Abreu, que são: máscaras, panelas e cavalinho de cerâmica. 
Figura 11: Máscaras de cerâmica

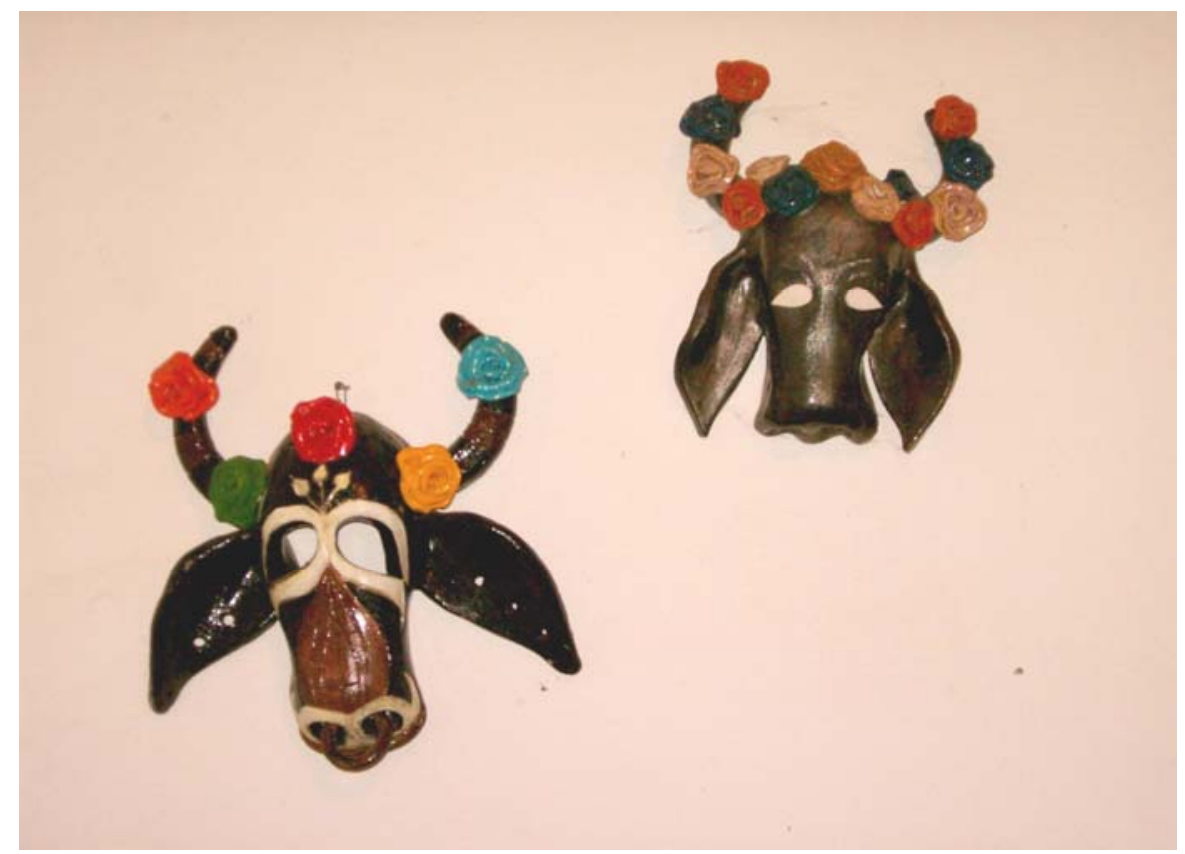

Fonte: Rodrigues, Ludmilla. Pirenópolis. 30 de Março de 2005

Figura 12: Panelas, cavalinho e máscara de cerâmica

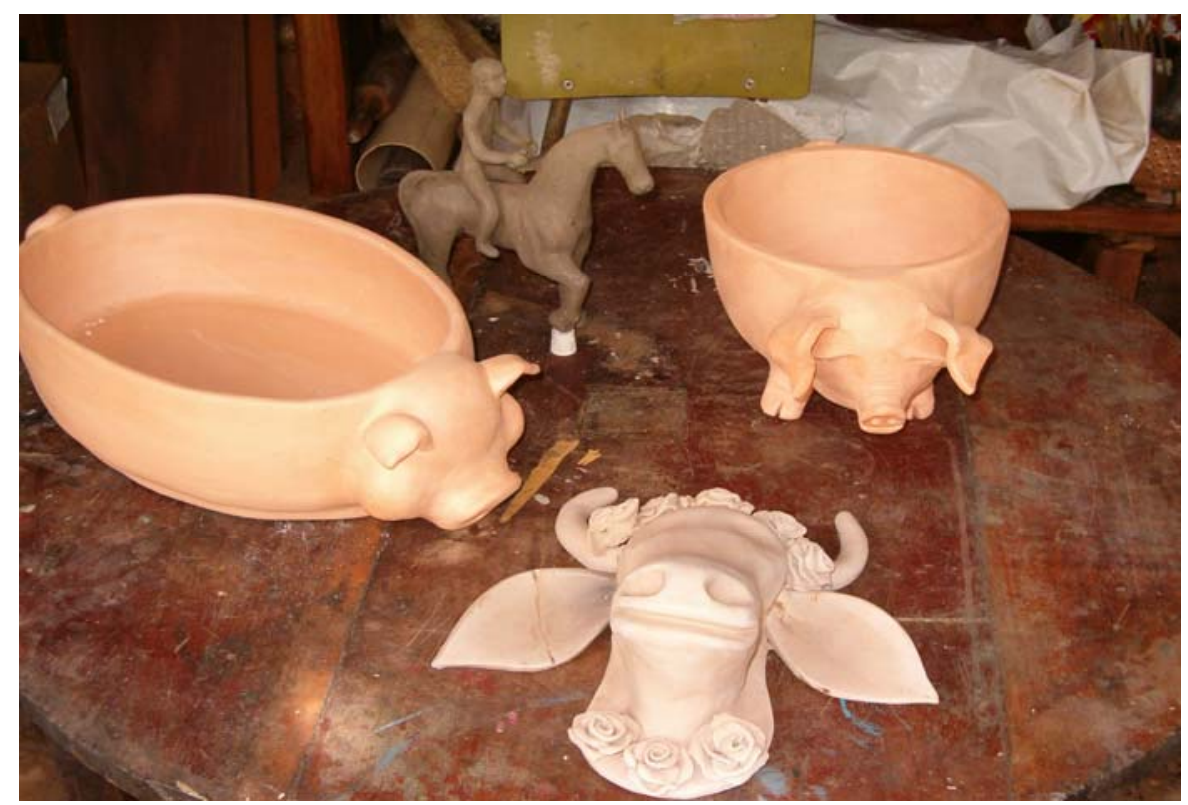

Fonte: Rodrigues, Ludmilla. Pirenópolis. 30 de Março de 2005 


\subsection{Pintura}

O artesão começou a desenhar em 1940 com 8 anos de idade e usava carvão. Naquela época encontrava-se carvão na cidade com muita facilidade. Ele desenhava nas ruas de Pirenópolis, carros de boi, cavalo, etc. Depois de algum tempo abriu um cinema na cidade, sempre ia assistir filmes e começou a pintar atrizes famosas.

Forzani (2005) comenta: "Na época que o cinema abriu em Pirenópolis eu assistia aos filmes só para pintar as atrizes famosas. Eu pintava Sofia Loren, Brigith Bardot, etc".

Com o passar dos anos ele foi aprendendo com uma sobrinha a mecher com a tinta a óleo. E em 1960 ele começou a desenvolver e aprimorar suas próprias técnicas. Usa de muita criatividade para pintar e no total já são 264 quadros.

A pintura do Sr. Forzani é uma pintura em alto relevo e procura pintar paisagens, pessoas que representa ou representaram muito para a cidade, as Cavalhadas, as igrejas e coisas típicas da cidade.

Forzani (2005) diz: "A pintura é o meu trabalho, um incentivo, um estímulo na minha vida, pois fiquei doente e encontro forças nele. É também de onde eu retiro o meu sustento e pago meus remédios e meu médico".

Os principais materiais utilizados pelo artesão são: lápis, tinta a óleo, a moldura, a tela e o pincel. E um primeiro momento ele decide o que vai pintar, depois risca a tela a lápis, em seguida pinta com a tinta a óleo e por fim dá os retoques finais. 
Forzani (2005) declara: "Eu adoro o que eu faço, adoro pintar e procuro sempre estar passando para outras pessoas esta arte, as técnicas, pois quero que meus conhecimentos sejam propagados, manifestados e sirvam de estímulo para novos artistas e criações".

Ele acredita que a pintura pode incentivar outras produções artesanais, contribuir para a cultura local, se tornando parte do patrimônio da cidade.

O trabalho do Sr. Forzani começou a ser divulgado e reconhecido quando um pintor russo (Pauliolovith) que fazia pinturas modernas, viu seus quadros e ficou encantado. Comprou quadros e levou para São Paulo, Brasília, Rio de Janeiro, etc.

Segundo Forzani (2005): "Uma outra pessoa que me ajudou muito na divulgação do meu trabalho foi Regina Lacerda e também fiz um quadro do filme $O$ Tronco para o diretor da Rede Globo de Televisão, quando este veio para a cidade gravar o filme".

O artesão procura divulgar o seu trabalho através de amigos e recebe muitas encomendas. São pessoas de várias partes do Brasil e do exterior, como: Brasília, São Paulo, Paraná, Alemanha, Japão, Dinamarca, Suíça, Estados Unidos, Inglaterra, etc.

O Sr. Forzani não é cadastrado na Associação, pois acredita que a divulgação do seu trabalho é mais bem feita de boca a boca e também não acha importante o cadastro.

Para ele o artesanato proporcionou o aumento de empregos na cidade e o turismo. E conseqüentemente o aumento do turismo contribuiu para o surgimento de novos pintores na cidade, mais ou menos uns 60 pintores. 
Quanto a divulgação do artesanato de uma maneira geral, ele acredita que deveria ter mais incentivo da prefeitura e da Secretaria de Turismo de Pirenópolis.

$\mathrm{Na}$ página seguinte seguem-se as fotos de algumas peças produzidas pela $\mathrm{Sr}^{\mathrm{a}}$. Abreu, que são: quadros pintados com tinta a óleo. 
Figura 13: Quadro da Igreja Nossa Senhora da Lapa - pintado no ano de 2000

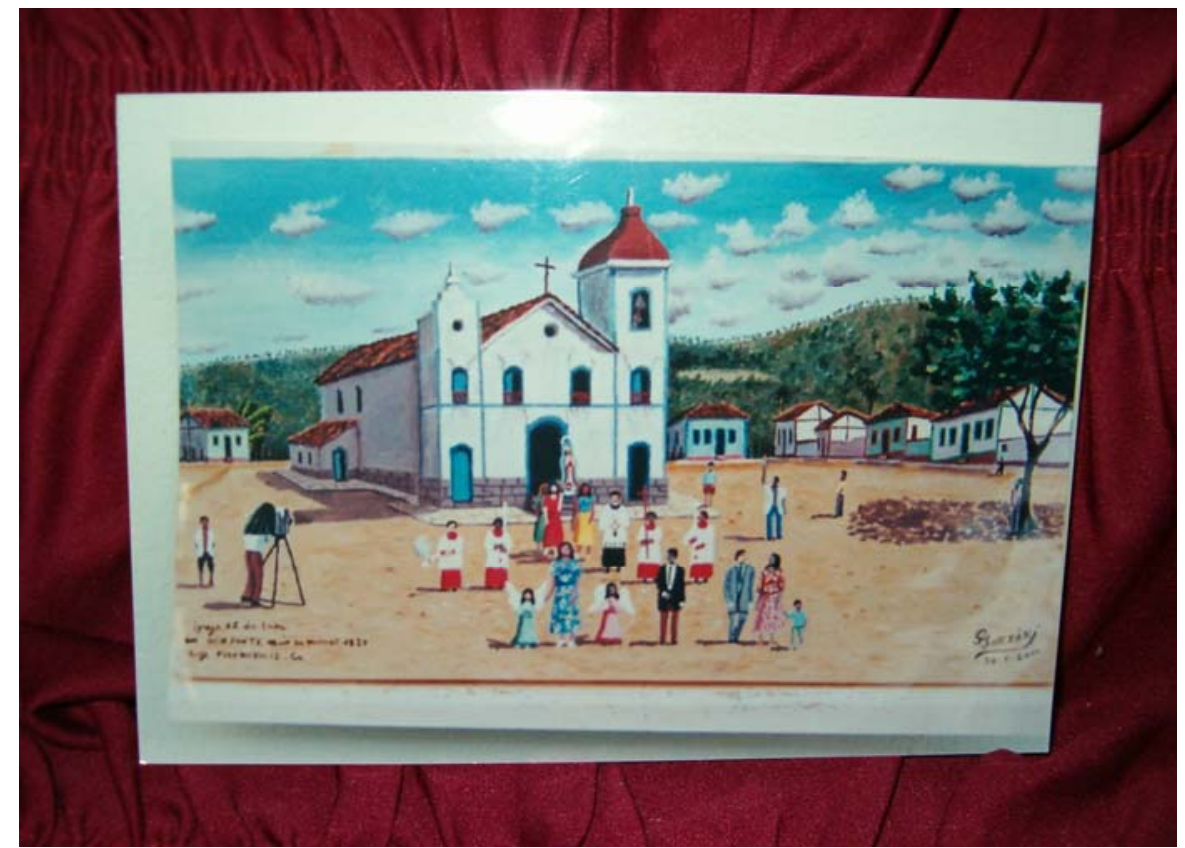

Fonte: Rodrigues, Ludmilla. Pirenópolis. 30 de Março de 2005

Figura 14: Quadro em fase de acabamento

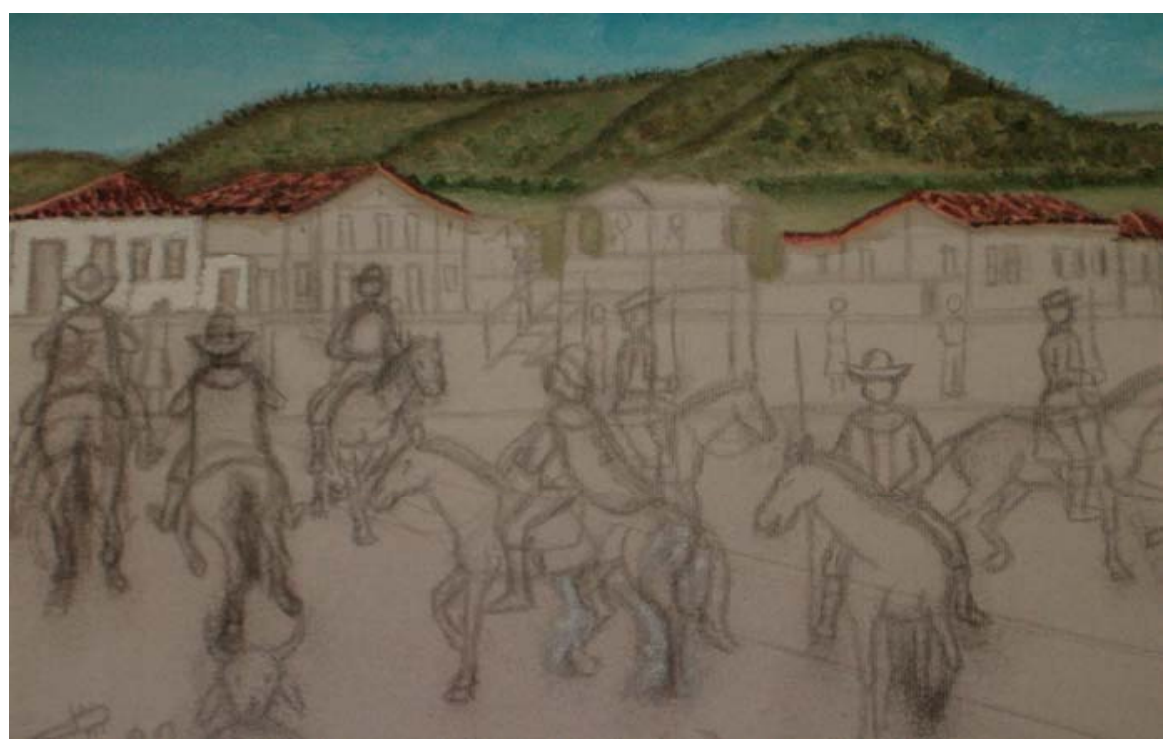

Fonte: Rodrigues, Ludmilla. Pirenópolis. 30 de Março de 2005 


\subsection{Móveis rústicos}

Os móveis rústicos surgiram em Pirenópolis há poucos anos, quando os marceneiros da região começaram a aproveitar as madeiras mortas das árvores e trabalhá-las, fazendo móveis para a casa em geral, como: mesas, bancos, estantes, etc. Antes o que se encontrava na cidade era os móveis em estilo colonial, mais pesados e semelhantes aos do Pará e de Minas Gerais.

O artesão começou a trabalhar como marceneiro em sua oficina e fazia móveis em geral, mais no estilo colonial. Com o passar dos anos começou a desenvolver e aprimorar suas técnicas, fazendo os primeiros móveis rústicos. Os primeiros móveis eram feitos com as rodas dos carros de boi, e só depois começou a usar as madeiras mortas das árvores.

Lobo (2005) comenta: "Este artesanato representa muito para minha vida, pois é de onde eu retiro o meu sustento e o da minha família. Eu ajudo muita gente na minha oficina, pois tem bastante serviço".

O Sr. Lobo ainda diz que o seu artesanato tem contribuído muito para o enriquecimento da cultura local, pois ele acredita que a arte dos móveis rústicos veio da própria cidade e da criatividade da comunidade local.

Os materiais utilizados para a fabricação dos móveis rústicos são os seguintes: madeira morta das árvores, a motossera, a furadeira, a lixadeira, o verniz e a cera. Primeiro o artesão decide qual móvel vai fazer, depende também do formato da madeira; em seguida corta a madeira, depois lixa e por fim passa o verniz ou a cera e dá o acabamento final. 
As árvores mais utilizadas para sua produção são a sucupira, angico, jatobá, tamboril, etc. São extraídas da própria região e algumas vezes quando clientes pedem, buscam a madeira do Pará (Angelim em pedra) para fazer os móveis rústicos.

De acordo com Lobo (2005):

"Eu aprendi as técnicas da madeira com meu pai que também era marceneiro e acabei aprendendo algumas coisas sozinho com a minha própria marcenaria. Trabalho há 10 anos com este ofício e procuro passar as técnicas para meus filhos".

Apesar do pouco tempo dos móveis rústicos na cidade, ele já está se transformando em tradição. No caso do Sr. Lobo ele procura ensinar para os filhos, que trabalham com ele desde pequenos e está ensinando também para o genro. No total são 8 pessoas trabalhando na sua oficina.

Lobo (2005) diz: "Existe cerca de 25 ou 30 fábricas de móveis em Pirenópolis, seja eles rústicos ou não e isso tem proporcionado a geração de empregos para muitas pessoas".

O artesão costuma comercializar e divulgar a sua produção artesanal em sua própria loja, aceita encomendas e também expõe em feiras quando é convidado. As encomendas vêm de Brasília, Goiânia, Tocantins, São Paulo, etc.

O Sr. Lobo é cadastrado na Associação e acha importante este cadastro para maior divulgação de seus móveis e mais contato com feiras a serem realizadas em outros estados.

O artesão acredita que o turismo tem melhorado e aumentado a produção artesanal. No caso do seu artesanato, ele tem feito 30 peças por mês, como 
bancos, estantes, entre outros. O artesanato também tem gerado muitos empregos na cidade e tem proporcionado melhoria de vida para a comunidade local.

Uma das maiores dificuldades que o Sr Lobo enfrenta é a falta de uma Secretaria do Meio Ambiente para orientá-los e ajudá-los sobre as áreas de preservação ambiental da cidade e a documentação necessária da empresa. Assim poderiam agir legalmente sem prejudicar ou degradar o meio ambiente.

Lobo (2005) comenta: "Por enquanto a preservação do meio ambiente depende da consciência de cada artesão de móveis rústicos, mas é necessário e urgente uma Secretaria do Meio Ambiente na cidade".

O Sr. Lobo ainda comenta também que o IBAMA tem reclamado bastante da falta de uma Secretaria do Meio Ambiente para controlar o corte da madeira e fiscalizar as ações dos artesãos de móveis rústicos da cidade.

Segundo Lobo (2005):

Os artesãos estão preocupados com a situação da cidade e com a preservação das árvores. Por isso alguns deles costumam ajudar os fazendeiros repondo mudas de árvores. Eles costumam repor cerca de 2000 mudas de tamboril de uma vez, mas só isso não é suficiente, os artesãos precisam é da orientação de um órgão público competente.

Quanto à prefeitura e a Secretaria de Turismo o Sr. Lobo diz que precisariam apoiar mais os artesãos na divulgação e na comercialização dos seus artesanatos.

$\mathrm{Na}$ página seguinte seguem-se as fotos de algumas peças produzidas pelo Sr.Lobo, que são: estante e banco estilo rústico. 
Figura 15: Estante estilo rústico

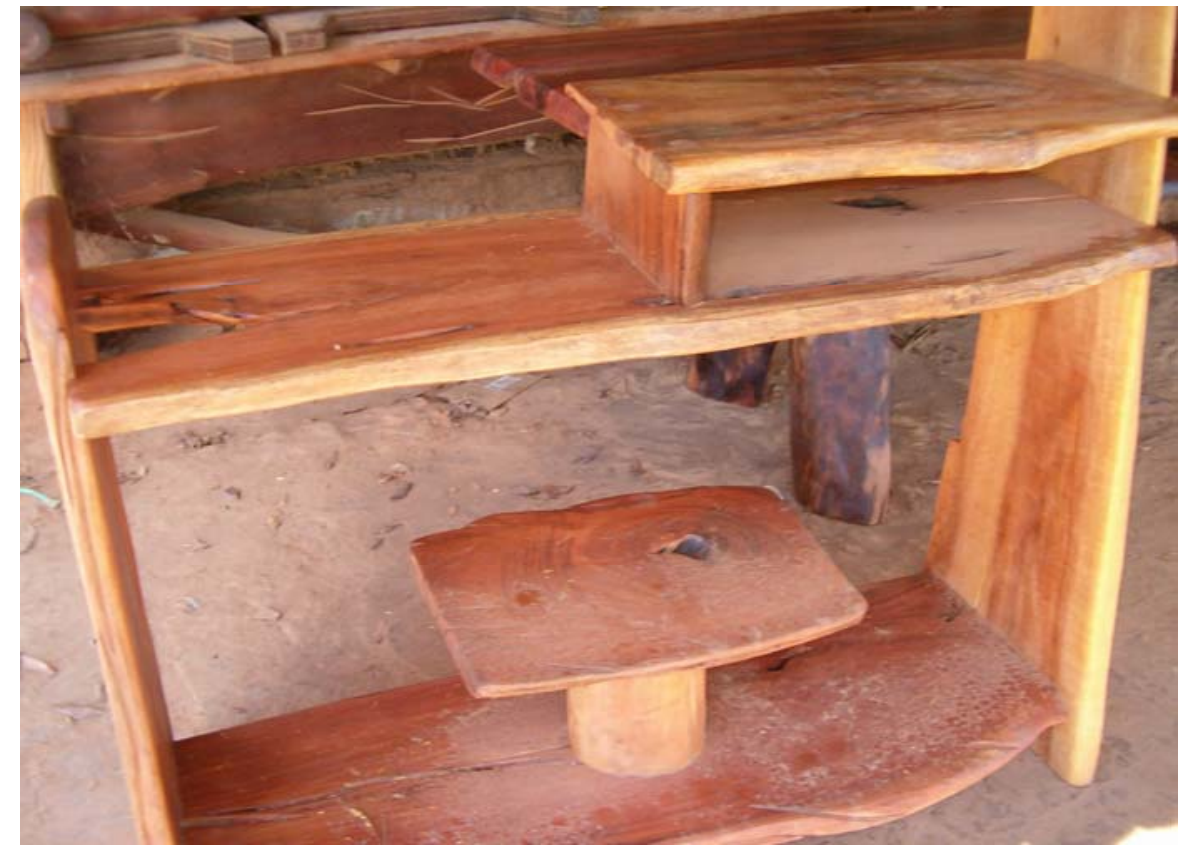

Fonte: Rodrigues, Ludmilla. Pirenópolis. 31 de Março de 2005

Figura 16: Banco estilo rústico

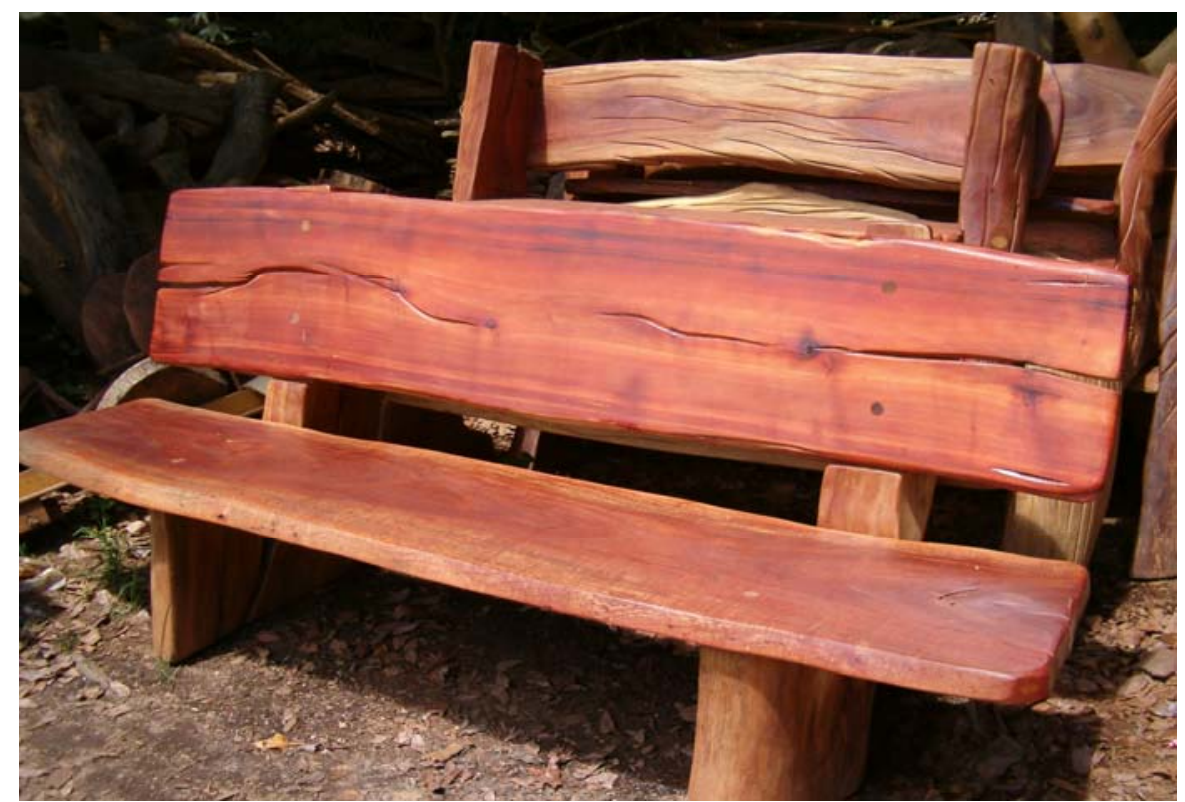

Fonte: Rodrigues, Ludmilla. Pirenópolis. 31 de Março de 2005 


\subsection{Doces}

A arte de se fazer doce é antiga na culinária da cidade de Pirenópolis e no Estado de Goiás. É uma tradição que já vem de muitos e muitos anos, quando a filha aprendeu com a mãe, que aprendeu com a avó e assim por diante.

Os doces eram feitos antigamente para a própria casa e para a família e hoje é comercializado e sustenta muitas famílias de Pirenópolis.

Goulão (2005) comenta:

"Procuro passar os meus conhecimentos, as técnicas e o ponto certo dos doces para as minhas filhas que trabalham comigo e tem muito interesse em aprender. No meu caso aprendi com minha mãe, que aprendeu com sua mãe, mas cada uma tinha uma sensibilidade para esta arte".

Os doces são feitos de várias frutas e procura sempre utilizar as da época e da região de Pirenópolis. Os doces são feitos das seguintes frutas: banana, laranja, goiaba, cagaita, mangaba, araçá, figo, limão, ameixa, buriti, limão, abacaxi, etc. São doces em compota e cristalizados.

Segundo Goulão (2005):

"Os doces que tem mais saída são os de leite, figo, baba de moça e ambrosia e são estes que os turistas mais gostam. O doce de minha preferência é o de leite com ameixa"

As frutas são colhidas de fazendas locais e da chácara da própria artesã. Ela preocupa-se em plantar e sempre fazer os doces com frutas da região, por isso há um incentivo muito grande por parte dela em plantar mudas e não comprar de outros estados. 
Goulão (2005) diz: "As frutas são da região mesmo. O único doce que a fruta não é da região, é o marmelo. Este vem de São Paulo e que provavelmente vem do Chile".

Os materiais utilizados para a produção dos doces são: uma fruta de boa qualidade; o tacho, que normalmente é de cobre; açúcar e uma colher de madeira. Primeiro a doceira limpa e lava a fruta, em seguida descasca e corta, depois coloca no tacho e acrescenta o açúcar. No caso do doce de leite utiliza-se apenas leite e açúcar. Espera-se de 3 a 4 horas, depois retira do fogo.

De acordo com Goulão (2005):

"Enquanto o doce estiver no fogo não deve mecher, pois isso pode desfazer a fruta. No caso do doce de leite mecher apenas no final do processo".

A Sra Goulão comenta que trabalha há 19 anos neste ofício e com o passar dos tempos foi aprimorando e aperfeiçoando suas técnicas e hoje faz cerca de 30 qualidade de doces por mês.

A artesã costuma divulgar seus doces e a comercializar em sua loja e participa do Festival de Gastronomia de Pirenópolis, que já é bem conhecido pelos turistas. Participa também de feiras, exposições em Brasília, festas locais e aceita encomendas de Goiânia, Minas Gerais, etc.

A Sra Goulão não é cadastrada na Associação, e não se cadastrou por achar desnecessário, pois acredita que já tem uma boa divulgação de seus produtos.

O artesanato tem proporcionado o aumento do turismo na cidade; geração de emprego, só ela emprega 10 pessoas; divulgação das belezas naturais (cachoeiras, reservas, lagos, etc) e melhoria de vida para todos. 
O turismo é um forte aliado dos artesãos, pois promove o aumento da produção e acaba contribuindo para a formação de novos artesãos. O aumento da produção artesanal gerou mais renda e oportunidades para a comunidade local.

Mas a artesã acredita que ainda falta muita ajuda da prefeitura na divulgação do artesanato local. Ela acha que poderia ter mais incentivo na comercialização dos produtos e uma maior variedade.

$\mathrm{Na}$ página seguinte seguem-se as fotos de alguns produtos produzidos pela Sra.Goulão, que são os doces.

Ver Apêndice A - Roteiro de entrevista aplicado aos principais Artesãos de Pirenópolis (p. 99) 
Figura 17: Doces de várias especialidades (leite, mamão, caju, ameixa, etc)

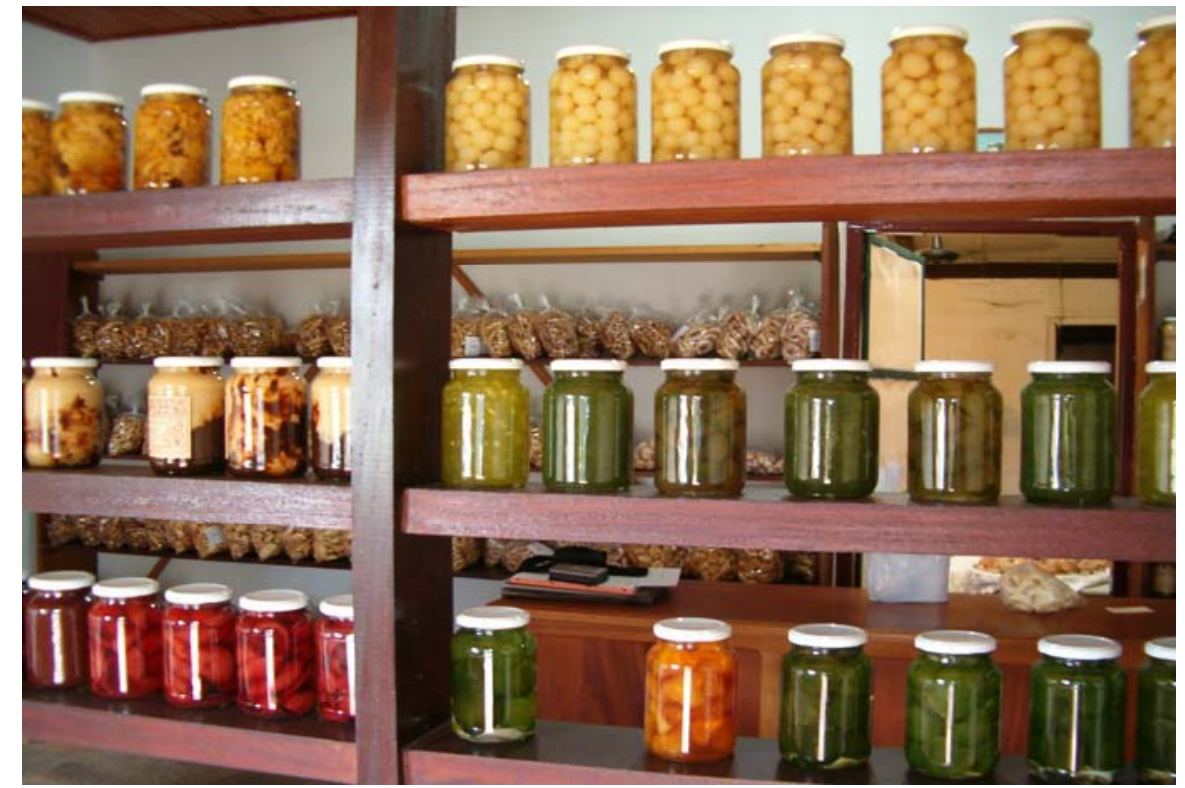

Fonte: Rodrigues, Ludmilla. Pirenópolis. 31 de Março de 2005

Figura 18: Doce de caju

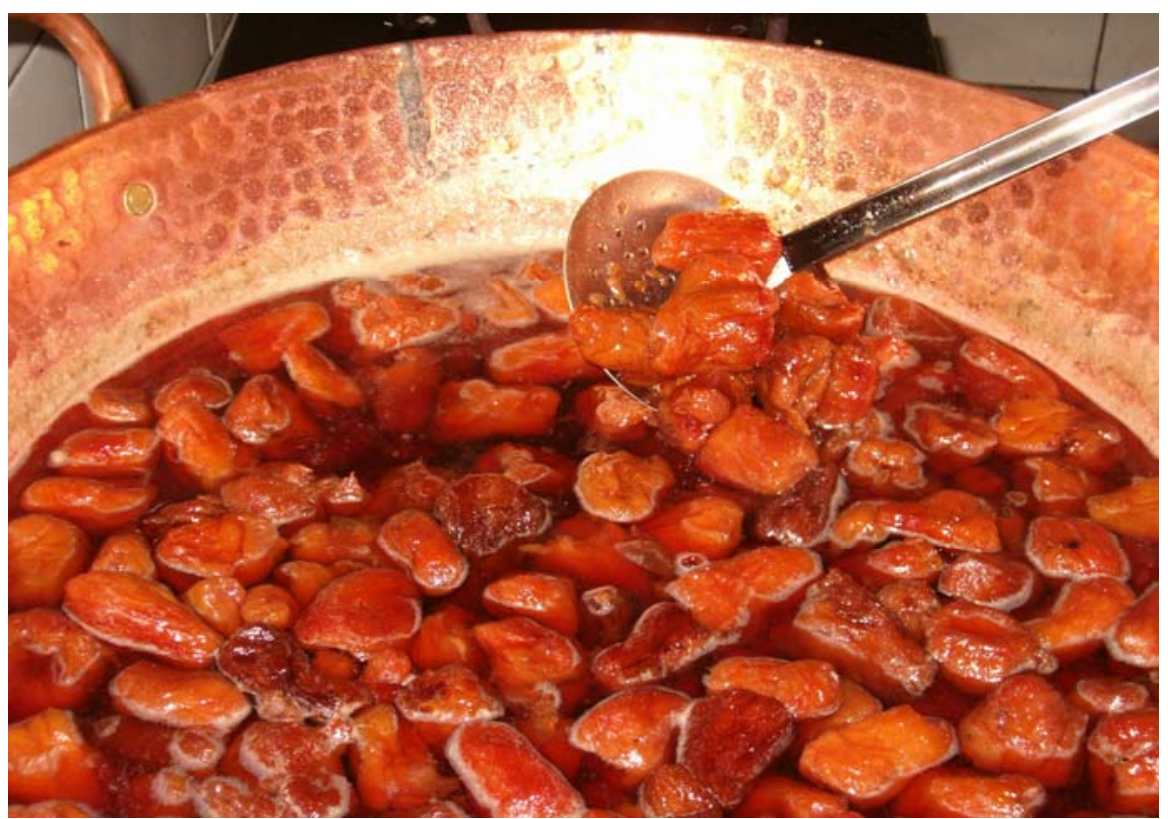

Fonte: Rodrigues, Ludmilla. Pirenópolis. 31 de Março de 2005 
3. Análise das diferentes visões dos artesãos de Pirenópolis

Definido o que é comunidade no Capítulo anterior e como ela se organiza, pôdese constatar que os artesãos de Pirenópolis formam uma comunidade integrada, que tem interesses em comum e que partilham da mesma riqueza cultural.

Com os conceitos de lugar, não-lugar, espaço, cidade, pôde-se definir Pirenópolis como sendo uma área propriamente urbana, um espaço, onde há trocas de conhecimentos, práticas culturais, turismo e que é movida por serviços.

Com a definição de memória, memória individual e coletiva pôde-se observar que a riqueza cultural de Pirenópolis, seus valores coletivos estão sendo passados através do artesanato local. Enquanto uns artesanatos foram sendo aprendidos por herança familiar outros foram sendo aprendidos com mestres, amigos, cursos, etc.

Verificou-se que o joalheiro, o escultor e a ceramista aprenderam a fazer os seus artesanatos com mestres. Mas com o tempo foram aperfeiçoando e aprimorando as técnicas. Já as colchas de retalho, os móveis rústicos e os doces têm tradição familiar, vem sendo passado de geração a geração, de pai para filho. E no caso das máscaras, da tecelagem e da pintura foram ensinadas por amigos.

Constatou-se que as máscaras também têm tradição na cidade, pois está presente na folia dos Mascarados durante a Semana Santa em Pirenópolis. Mas hoje os mais jovens estão esquecendo o verdadeiro sentido da Semana Santa, a festa está perdendo um pouco os seus valores, a sua identidade. Há uma perda da identidade porque eles estão mais interessados em aparecer com suas roupas coloridas e máscaras enfeitadas. 
No caso da cerâmica os mais jovens não estão querendo trabalhar a argila, a aprender as técnicas, ou seja, eles não têm nenhum interesse em dar continuidade ao processo. Uma ONG tem ajudado a resgatar o interesse deles pela cerâmica, mas ainda precisa de muito apoio da Prefeitura e da Secretaria de Turismo.

Verificou-se que o mesmo problema acontece com as colchas e os tapetes de retalho. Os mais jovens não querem aprender como se faz este artesanato. Eles não têm interesse nesta arte. Precisaria de um apoio da Prefeitura para reverter esta situação. Este apoio poderia ser por meio de cursos conscientizando a comunidade local da importância do artesanato para a cultura local.

Para todos os artesãos entrevistados, artesanato é uma arte e faz parte da memória, da cultura, da tradição, da identidade do povo e do patrimônio cultural da cidade. E acima de tudo consideram o artesanato como fonte de renda e sustento para suas famílias e suas vidas.

Identificou-se que todos os materiais e as técnicas utilizadas são simples e que os artesanatos são feitos manualmente usando-se matérias - primas da região ou de outros estados como: São Paulo, Anápolis, Jaraguá, etc.

Observou-se, no entanto, que todos os artesãos entrevistados trabalham com o sistema de encomendas, além de comercializarem seus produtos em suas próprias lojas, como é o caso do joalheiro, da tecelã, da doceira e do artesão em móveis rústicos. O escultor em pedra, a ceramista e o joalheiro comercializam e divulgam seus artesanatos na Feira das Artes, enquanto a tecelã, a doceira e o artesão em móveis rústicos comercializam e divulgam seus artesanatos em outras feiras. Já a ceramista e a artesã em colchas e tapetes de retalho comercializam e divulgam seus artesanatos em suas próprias casas. E por fim, apenas o escultor em pedra comercializa e divulga seu artesanato em outras lojas. Portanto todos os artesãos comercializam seus produtos em diversos lugares. 
Utilizou-se para este trabalho do cadastro da Associação de Joalheiros e Artesãos de Pirenópolis (AJAP), os seguintes artesãos: joalheiro, tecelã e o artesão em móveis rústicos. Por esta Associação não ter todas as lideranças dos principais tipos de artesanato cadastrados, foram utilizados a parte, os seguintes artesãos: escultor em pedra, colchas e retalhos, máscaras de papel, ceramista, pintor e a doceira.

Constatou-se que os artesanatos de colchas e tapetes de retalhos, a cerâmica, a pintura, os móveis rústicos e os doces são de origem local, enquanto a escultura em pedra e a tecelagem tiveram influência de outros estados. Já as máscaras tiveram influência de outro país. E por fim apenas as jóias de prata tiveram influência de outros estados e países.

No caso das jóias de prata tiveram influência dos hippies (argentinos, espanhóis, colombianos, uruguaianos, mineiros, paulistas, etc). As jóias de prata perderam um pouco a sua autencidade, na medida em que os artesãos locais passaram a incorporar os conhecimentos destes hippies em suas peças.

A escultura em pedra teve influência de São Tomé das Letras - MG, pois o artesão aprendeu a esculpir e moldar a pedra de acordo com os conhecimentos do seu mestre mineiro. Só com o passar dos anos o artesão foi aperfeiçoando suas técnicas e desenvolvendo seu próprio estilo.

Verificou-se, portanto, que apesar da influência mineira, há uma contribuição positiva para a identidade local, pois o artesão acabou incorporando ao trabalho aprendido, sua criatividade. Procura fazer fachadas da cidade, das igrejas, valorizando a cultura local. É um tipo de identidade inventada, mas sem perda da autenticidade. 
Quanto à tecelagem, esta teve influência de São Paulo, pois a artesã aprendeu as técnicas em um curso com uma amiga paulista. Suas técnicas foram sendo aprimoradas quando ela entrou em contato com a cultural local da cidade, ou seja, ela passou a incorporar seu trabalho a realidade e linguagem da cidade.

Já as máscaras de papel vieram de Portugal, não se sabe ao certo quem as produzia. Mas o artesão procurou aprimorar suas técnicas e aplicá-las de acordo com a cultura local. Como é o caso da Semana Santa, onde acontece as famosas Cavalhadas e a folia dos Mascarados.

Constatou-se, portanto, que a tecelagem e as máscaras de papel foram outras identidades inventadas e reinventadas e que contribuíram e ainda contribui para a formação da cultura local.

Portanto a identidade cultural de Pirenópolis vem sendo formada pela cultura local e pela influência de outros estados e países.

De acordo com as repostas dos entrevistados, acredita-se que o artesanato local tem proporcionado o aumento do turismo na cidade, a geração de empregos, o surgimento de novos artesãos, a melhoria na qualidade de vida dos artesãos, divulgação de outros atrativos da cidade (cachoeiras, Parque dos Pireneus, etc) e o crescimento e desenvolvimento da cidade.

Portanto o artesanato é um bem cultural que precisa ser preservado e valorizado a cada dia e que faz parte da cultura local e do patrimônio imaterial da cidade.

Verificou-se, que as maiores dificuldades enfrentadas pelos artesãos são em relação à divulgação e comercialização de seus produtos. A tecelã ainda comenta que há uma produção idêntica, sem criatividade de alguns artesanatos na cidade. Já a ceramista destaca que há um problema muito grande em se encontrar a argila na região e quando se encontra, ela está em ares de preservação ambiental. Por fim o artesão em móveis rústicos destaca outra dificuldade, que é 
em relação à falta de uma Secretaria do Meio Ambiente para orientar os artesãos e fiscalizar suas ações.

Observou-se que um outro problema poderá vir a acontecer no futuro, a degradação das Pedreiras, devido a retirada e o uso ilimitado das pedras (quartzito) pelos escultores em pedra.

Portanto deve-se haver uma conscientização dos artesãos para o uso adequado dos recursos que a cidade dispõe.

Conforme verificou-se, os artesãos acreditam que precisam ser tomadas algumas providências para melhorar a comercialização e a divulgação do artesanato local, como: maior integração dos artesãos e autoridades locais, criação de um guia dos artesãos, incentivo por parte da Prefeitura local e a criação de um Centro de informações sobre a cultura local; onde seriam mostrados os artesanatos produzidos pelos artesãos, livros, revistas e pessoas discutindo o assunto.

Pôde-se constatar que o artesanato local é um dos atrativos principais de Pirenópolis e que contribui para o aumento do fluxo turístico local. Com o aumento do fluxo turístico em Pirenópolis, acelera o processo de contínua invenção e reinvenção da arte, da tradição, dos valores, dos costumes, enfim, da cultura, pois as pessoas passam a fazer o artesanato para atender os turistas. Mas os artesãos locais avaliam positivamente esta aceleração, pois melhorou a geração de renda e de emprego. 
4. Análise das diferentes visões dos órgãos públicos sobre artesanato

Observou-se nesta parte da pesquisa como os órgãos públicos consideram o artesanato, como ele é trabalhado pelos mesmos e como é a estrutura destes órgãos para atender as necessidades dos artesãos do Estado de Goiás e do próprio país.

\subsection{Secretaria de Turismo de Pirenópolis}

De acordo com Ayer (2005): "Artesanato é a arte que você cria, podendo ter uma veia artística e utilitária, usando matéria-prima da região e que gera renda para a comunidade local".

$\mathrm{O}$ artesanato segundo o Sr. Ayer (2005), representa uma fonte de renda para a comunidade local. É de onde as pessoas retiram o seu sustento, pagam suas contas e alimentam suas famílias.

Os principais tipos de artesanatos existentes em Pirenópolis são: a cerâmica, a tecelagem, as máscaras de papel, cestaria, colchas de retalho, doces, as jóias de prata, vestuário e acessórios, móveis rústicos, pequenos objetos de madeira, bijuterias feitas com sementes e cascas de árvores, pintura, etc.

Segundo Secretário de Turismo de Pirenópolis alguns artesanatos sofreram influências de outros estados e países, como é o caso das jóias de prata, das máscaras de papel, da tecelagem, das esculturas em pedra, etc. E de acordo com sua opinião isso é bom para alguns artesanatos e ruins para outros. Como é o caso das jóias de prata. Ele costuma freqüentar a Feira das Artes e acha tudo muito repetitivo, sem criatividade e muito parecido também com as jóias indianas. 
Já no caso das esculturas em pedra ele acredita que a influência de outro estado foi positiva, pois contribuiu para fortalecer a identidade local e os artesãos que fazem este tipo de artesanato, procuram usar suas criatividades fazendo peças que representem os patrimônios da cidade, como por exemplo: fachadas das igrejas, paisagens locais, fachadas das casas, etc.

Ayer (2005) comenta:

"Os turistas acham as esculturas em pedra um artesanato muito representativo da cidade e sempre compram uma lembrancinha para levarem para suas casas. E isso contribui para o aumento da economia da cidade, pois os artesãos acabam produzindo muito para atender o fluxo turístico e as encomendas que surgem".

No caso das máscaras de papel ele acredita que acrescentou muita alegria para a Semana Santa e também par a comunidade local, que fica o ano todo preparando e ensaiando para as apresentações locais, como as Cavalhadas e a folia dos Mascarados, e outras ainda.

Mas ele pensa que o mais importante a ser considerado pela comunidade local é o verdadeiro sentido da Semana Santa, ou seja, o seu caráter religioso. Mas o que vem acontecendo é uma perda da tradição, pois os jovens não querem saber de envolver-se com a preparação da festa, e passam a ter outros interesses.

Mas quando é perguntado sobre o que a prefeitura e a Secretaria têm feito para ajudar na preservação da cultura local, o Secretário desconversa o assunto.

Constatou-se que deveria existir maior incentivo por parte das autoridades locais. Deveriam ser realizados cursos, oficinas, palestras, etc, para resgatarem novamente os interesses destes jovens a cerca de algumas tradições da cidade. 
Quanto ao que o artesanato tem proporcionado para a cidade de uma maneira geral, o Sr. Ayer (2005) diz:

"O artesanato tem melhorado a vida dos artesãos e da comunidade local, tem aumentado o turismo na cidade e tem contribuído para a divulgação dos recursos naturais. As pessoas vão em busca do artesanato e acabam encontrando uma variedade de opções"

De acordo com o Sr. Ayer a Secretaria de Turismo juntamente com a AGETUR tem um projeto de realização de feiras de artesanato em Pirenópolis. Estas feiras seriam realizadas cada uma em uma época, com artesanatos diferentes e ficariam na cidade normalmente por 15 dias.

A primeira feira já foi realizada em abril deste ano e tinha como artesanato a cerâmica. Havia 14 artesãos expondo os seus trabalhos. (Ver Apêndice H, p. 106)

De acordo com Ayer (2005): "A próxima feira será sobre tecelagem, mas não sei se vamos conseguir agregar todos os artesãos da cidade. Mas pretendo sempre trabalhar com os artesãos levando idéias".

O objetivo destas feiras em Pirenópolis é confrontar os artesãos locais para que eles conheçam os trabalhos de outros artesãos e comecem a produzir peças diferentes, criativas, mas sem descaracterizar o seu artesanato e sem alterar o seu valor cultural.

Segundo Ayer (2005): "A feira vai tentar trabalhar com os ceramistas dando a eles idéias do que é vendável ou não. Não é para eles perderem suas tradições, mas sim aprimorar o seu artesanato." 
$\mathrm{Na}$ verdade este projeto de feiras em Pirenópolis faz parte do Projeto Oficina de Design e Capacitação dos Artesãos do Estado de Goiás. Este projeto será aplicado em 15 Municípios goianos. E a primeira cidade do Estado foi Pirenópolis, com uma Feira e oficina de cerâmica. Este projeto tem como finalidade desenvolver oficinas nos Municípios de acordo com suas aptidões artesanais. É um projeto apoiado pelo MinTur e busca estimular o desenvolvimento turístico e econômico de cada uma das cidades selecionadas.

Além deste Projeto em parceria com a AGETUR a Secretaria de Turismo tem uma loja de artesanato chamada Piretur, onde se comercializa o artesanato local.

Ayer (2005) destaca:

\footnotetext{
O que a Secretaria tenta fazer através do Projeto das feiras e da Piretur é mostrar para os artesãos que os seus produtos tem valor, qualidade e tem que ser preservados, pois representa a cultura do povo. Mas em um primeiro momento o projeto vai mostrar como os artesãos podem trabalhar o seu artesanato, com criatividade e produzindo peças inovadoras.
}

Ele considera também a Piretur uma loja pequena, falta organização dos produtos nas prateleiras e isso inibe um pouco as vendas. Por isso o Projeto das feiras são tão importantes, pois além de proporcionar conhecimento de novos trabalhos para os artesãos, desperta a atenção dos turistas.

O Secretario diz também que o SEBRAE propõe para a Secretaria de Turismo uma nova linguagem de trabalho que se chama GEOR, que é o Gerenciamento Estratégico Objetivando Resultados. É um outro projeto que discute novas propostas, e artesanato é uma delas.

O Sr. Ayer juntamente com o SEBRAE e a AGETUR fizeram uma proposta para os artesãos e se for aceita, dentro de pouco tempo será articulada. O Sebrae fez uma iconografia (selo) para os produtos artesanais simbolizando que o artesanato é de Pirenópolis. Neste selo também virá o nome do artesão e da cidade. 
Ayer (2005) comenta: “Todos os artesanatos de Pirenópolis terão um selo, e isso acontecerá em pouco tempo. Isso vai ser muito bom para a cidade, pois ajudará a divulgar ainda mais os nossos produtos artesanais".

O Secretario comenta que o aumento do turismo tem proporcionado a abertura de muitas lojas de artesanato e com isso todos os tipos de artesanatos podem ser comercializados.

O Sr. Ayer diz que apesar dos projetos em parceria com a AGETUR e o SEBRAE, a Secretaria tem muito a contribuir para a cidade de Pirenópolis. E pretende se dedicar ao máximo para as feiras de artesanato se tornarem freqüentes na cidade.

Uma sugestão do Sr. Ayer para os artesãos ceramistas é que eles deveriam preocupar-se em fazer suas cerâmicas baseadas em animais típicos da região; paisagens; flores; festas; como por exemplo; os cavalinhos das Cavalhadas, as máscaras dos mascarados e utensílios da culinária local. Com isso eles ajudariam a preservar sua cultura, e sua identidade.

Ele acredita também que a nova prefeitura possa dar apoio aos trabalhos a serem realizados por ele na Secretaria e que contribuíram de alguma forma para o desenvolvimento da cidade.

Ver Apêndice B - Roteiro de entrevista aplicado ao Secretário de Turismo de Pirenópolis (p. 100) 
4.2 Associação de Joalheiros e Artesãos de Pirenópolis (AJAP)

Pereira (2005) diz: "Artesanato é a vida das pessoas desta cidade, é o meio pela qual trabalham e ganham o seu dinheiro. É uma arte que é dada como presente para o povo da cidade, e é o nosso patrimônio mais singelo"

Os principais tipos de artesanato de acordo com o Sr. Pereira são: cerâmica, máscaras de papel, colchas de retalho, tecelagem, móveis rústicos, escultura em pedra, doces, jóias de prata e a pintura.

O artesanato sempre existiu na cidade, mas antes era feito para uso doméstico e sob encomenda. Somente a partir dos anos $80 \mathrm{com}$ a divulgação da cidade que o artesanato começou a expandir. Hoje é mais organizado, comercializado em lojas, feiras e é vendido para vários lugares do Brasil, como: Goiânia, Brasília, São Paulo, Minas Gerais, etc e até para o exterior.

De acordo com Pereira (2005): "Antes o artesanato era feito para a própria casa, ou sob encomenda e não era vendido para outros lugares, permanecia dentro da cidade mesmo. $\mathrm{E}$ os mais antigos são as colchas de retalho, as máscaras de papel, a tecelagem, etc".

A comercialização do artesanato dentro de Pirenópolis começou a mais ou menos uns 25 anos, com a Piretur, que é uma loja de artesanato local vinculada à Secretaria de Turismo e a Prefeitura. A Piretur pega o artesanato do artesão para revender, coloca uma porcentagem em cima e vende para os turistas. Já as outras lojas de artesanato foram surgindo mais ou menos nos anos 90.

$\mathrm{O}$ artesanato influenciou bastante a comunidade local. Na medida em que as pessoas viram o retorno financeiro que o artesanato proporcionava, foram virando artesãos e daí foram surgindo novas linhas de artesanato e a criatividade aumentou. 
Pereira (2005) comenta: "Hoje tem artesanato dos mais diversos possíveis, feitos com sementes e cascas de árvores, esculturas em pedra, acessórios de bucha vegetal, etc".

Com o aumento dos artesãos na cidade, principalmente os artesãos joalheiros, houve uma necessidade de se criar uma Associação que thes defendesse e divulgasse os seus produtos. Mas em um primeiro momento era uma Associação só de joalheiros. Esta surgiu há $10^{\mathrm{a}}$ anos, em 1995. E com o passar dos anos, com a diversificação dos artesãos e dos artesanatos, a Associação virou Associação de Joalheiros e Artesãos de Pirenópolis (AJAP).

Para o surgimento desta nova Associação foi realizada uma reunião entre os diversos artesãos e os joalheiros. Então eles decidiram se unir, pois os outros artesãos não tinham nenhum órgão que os representasse dentro da cidade.

Pereira (2005) diz: "Quando a Associação foi fundada a grande maioria dos artesãos eram joalheiros, uns 80\%. Hoje em dia a Associação é mais conhecida como AJAP e tem este nome há 5 anos".

A AJAP é composta de um Presidente, um Vice-Presidente, um Secretário, um Vice-Secretário, um Tesoureiro, um Vice-Tesoureiro e o Conselho fiscal com 3 pessoas. A Associação não tem sede fixa, mas o presidente está tentando com Pompeu Cristóvão de Pina, organizador das Cavalhadas, uma sala no campo das Cavalhadas. Com uma sede fixa a Associação passará a ter mais organização e estrutura. 
Pereira (2005) comenta:

"Existe cerca de 185 artesãos cadastrados na AJAP, mas apenas 90 pagam em dia a mensalidade (Ver Anexo A, p. 111). A mensalidade é 5 reais e serve para despesas básicas de documentos, ligações, etc. A diretoria não é remunerada, e ela muda a cada 2 anos".

Para um artesão se tornar associado é exigido uma série de critérios. Primeiro o artesão procura a Associação, depois o Presidente ou alguém da diretoria realiza uma visita na casa do artesão, para ver se ele realmente trabalha. A exigência mínima para se cadastrar é estar morando na cidade há pelo menos 6 meses ou ser indicado por alguém.

Pereira (2005) declara: "É importante os artesãos se cadastrarem na Associação, pois esta trabalha para ajudar os artesãos na divulgação de seus produtos".

O presidente diz que o seu interesse pela Associação vem de muitos anos. Ele sempre participava das reuniões e ajudou na sua fundação. Já participou de outras gestões também, ocupando vários cargos.

O turismo proporcionou para a cidade uma maior divulgação e comercialização do artesanato local. Antes as pessoas produziam o artesanato para consumo próprio e hoje produzem em maior quantidade para a venda.

O Sr. Pereira acredita que o artesanato local teve influência de vários estados e até países, como: São Paulo, Minas Gerais, Colômbia, Espanha, etc. As máscaras de papel por exemplo tiveram influência de Portugal, as esculturas em pedra vieram de Minas Gerais, etc. 
O artesanato local contribuiu para a melhoria de vida dos artesãos e da comunidade em geral, para a geração de empregos, para a divulgação dos recursos naturais e para o desenvolvimento da cidade.

O Sr. Pereira acredita que as autoridades locais poderiam divulgar mais 0 artesanato da cidade, oferecer cursos para os artesãos, conscientizando eles da importância da cultura local.

Ver Apêndice C - Roteiro de entrevista aplicado ao Presidente da AJAP (p. 101) 
Figura 19: Associação dos Joalheiros e Artesãos de Pirenópolis (AJAP)

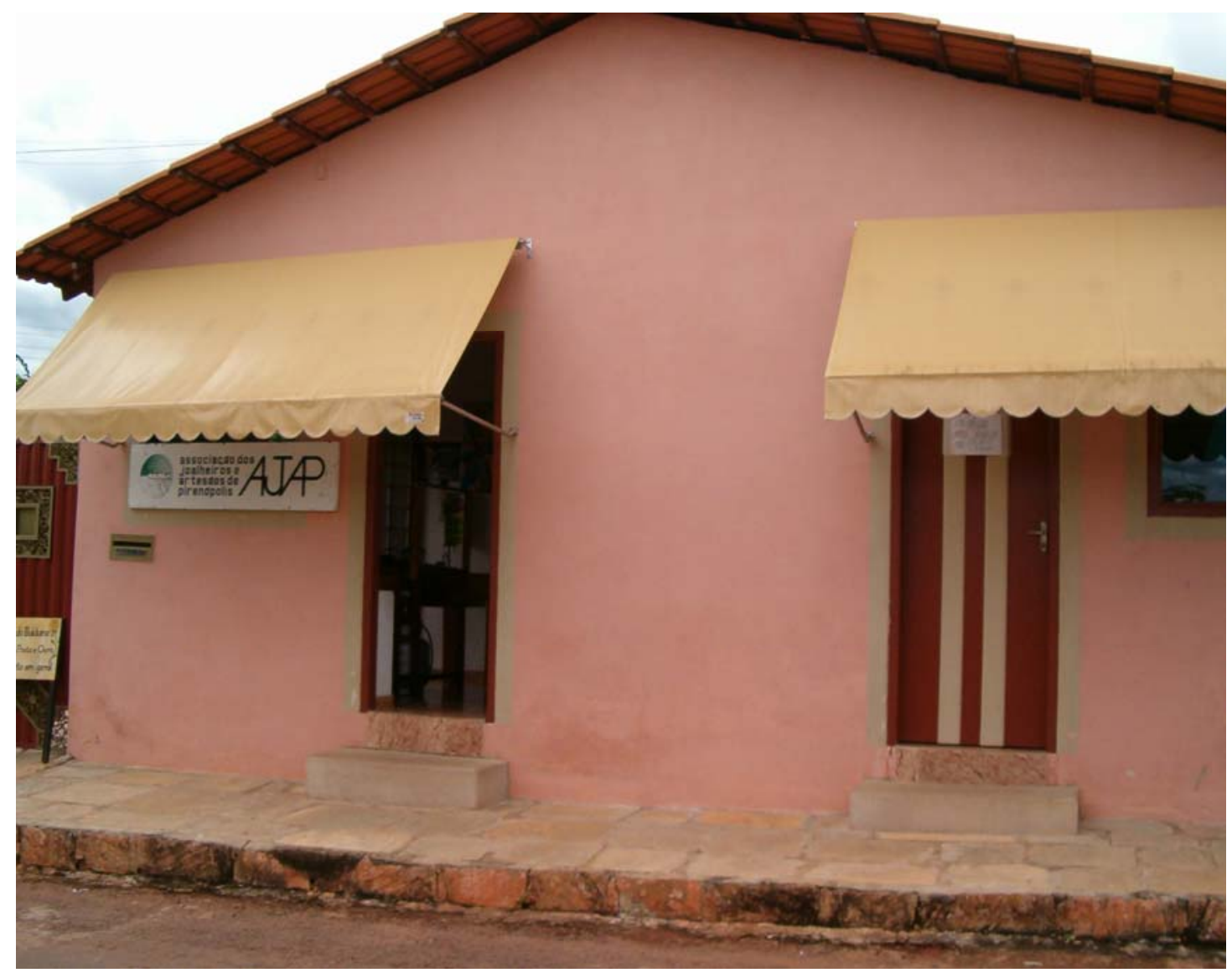


4.3 Agência Goiana de Turismo (AGETUR)

Veloso (2005) define: "O artesanato é um conjunto de criações culturais, baseada na identidade cultural e nas tradições de um grupo ou comunidade e que pode ser aprendida com mestres, amigos, cursos ou adquirida por herança familiar".

A AGETUR é um órgão estadual que trabalha e desenvolve o turismo e as atividades complementares a ele no Estado de Goiás. Ele está dividido em vários departamentos e gerências e uma de suas gerências é a Articulação Privada, onde o artesanato está inserido. O seu objetivo é trabalhar o artesanato de forma integrada com a comunidade local dos Municípios, valorizando a identidade cultural do povo goiano, promovendo a comercialização dos produtos, gerando emprego e renda aos artesãos.

O desenvolvimento do artesanato no Estado de Goiás começou com dois projetos. O primeiro projeto realizou-se no ano de 2002 e teve parceria com uma Associação chamada Acervo Goiano. Esta Associação tem sua sede em GoiâniaGO e trabalha com vários artesãos do Estado.

O projeto tinha como finalidade realizar oficinas e ensinar as técnicas artesanais para 8 mil jovens da rede de ensino público. Este projeto teve resultados tão positivos para o Estado que em 2002 a entidade foi eleita a mais representativa do Brasil.

O segundo projeto (Projeto Faber) foi realizado em março de 2005 e tinha como público alvo: artistas plásticos, arquitetos, designers, técnicos e/ou consultores da AGETUR e/ou SEBRAE e profissionais de áreas afins, interessados na atuação de programas de artesanato. 
O Projeto Faber foi um curso de fundamentos teóricos sobre artesanato e dedicouse à transmissão de conhecimentos por meio de aulas expositivas, palestras e conferências.

Um outro projeto que está sendo realizado atualmente pela AGETUR para beneficiar o artesanato do Estado de Goiás é o Projeto de Desenvolvimento do Artesanato Goiano. Este projeto tem parceria com o PAB estadual, o SEBRAE estadual e o apoio do Ministério do Turismo (Ver Anexo B, p. 111).

Veloso (2005) comenta: "O SEBRAE estadual fornece materiais e equipamentos necessários (data show, telão) para a realização das oficinas e o transporte para a equipe técnica".

Portanto, o SEBRAE é responsável somente por uma parte do projeto e não é encarregado de escolher os designers que vai atuar juntamente com os artesãos e nem como trabalhar as oficinas e as atividades dentro dos Municípios selecionados pela AGETUR.

O projeto é a realização de oficinas para os artesãos e exposições do artesanato local e tem como abrangência o levantamento das Associações de artesanato, cadastramento dos artesãos e dos tipos de produtos confeccionados, capacitação da mão-de-obra envolvida, adequação do design às necessidades do mercado, comercialização e estimulo à promoção e a divulgação do artesanato. Ele visa o desenvolvimento do artesanato em 15 Municípios do Estado de Goiás, são eles: Caldas Novas, Olhos D’Água (distrito de Alexânia), Alto Paraíso, Cavalcante, Cristalina, Aruanã, Paraúna, Goiânia, Cidade de Goiás, Pirenópolis, Trindade, Silvânia, Ipameri, Hidrolândia e Cachoeira Dourada.

O trabalho é realizado nos Municípios da seguinte maneira: em um primeiro momento a AGETUR manda um ofício para a Secretaria de turismo ou para a prefeitura da cidade, com data e hora marcada. Em um segundo momento liga 
confirmando, pede hospedagem e alimentação para a equipe técnica e um local para a realização das oficinas e exposições.

De acordo com Veloso (2005): “A equipe técnica é composta por 2 designers, 1 monitor (artesão local) e um coordenador das atividades (funcionário da AGETUR)".

Os designers ensinam aos artesãos como comercializar e como fazer para melhorar as técnicas e o acabamento das peças artesanais, com isso contribui para o aumento da produção, mas sem descaracterizar o produto.

O importante é ensinar sem interferir na identidade local, na cultura das comunidades, ou seja, ensinar, mas preservando as tradições, a história e as origens do artesanato local.

Este projeto teve início em 4 de abril de 2005 e será finalizado no dia 14 de julho de 2005. A primeira cidade a ser realizada as oficinas e exposições de artesanato foi Pirenópolis e a última será Olhos D’Água.

Veloso (2005) diz:

"A idéia deste projeto é dar aos artesãos uma iniciativa para que eles continuem a realizar oficinas e exposições de artesanato em suas cidades, pois isso contribuirá para a melhoria de vida da comunidade local, além de proporcionar uma melhor divulgação e comercialização do artesanato".

Compreende-se, portanto, que este projeto tende a ser um estímulo aos artesãos para melhorar sua produção e o designer de seu produto e com isso aumentar o turismo na cidade. 
Conforme Veloso (2005):

"O turismo influencia e muito o artesanato local da cidade, pois aumenta a produção, melhora o acabamento dos produtos, surgem novos artesãos, novas lojas de artesanato e melhora a qualidade de vida da comunidade local, que passa a viver do artesanato".

Compreende-se então, que o turismo contribui para o desenvolvimento do artesanato, a divulgação das belezas naturais da cidade, gerando renda e benefícios para toda a comunidade local.

Uma das maiores dificuldades enfrentadas pelo artesanato em Pirenópolis segundo Veloso, é quanto a comercialização dos produtos artesanais e a compra de matéria-prima.

Veloso (2005) comenta: "Os artesãos acreditam que a divulgação de seus produtos é deficiente e falta desempenho da Prefeitura e da Secretaria de Turismo de Pirenópolis".

A divulgação do artesanato poderia ser melhorada se os órgãos competentes investissem em mais exposições de artesanato, acordos com outras cidades para exposições em feiras e parcerias de projetos com órgãos federais.

Ver Apêndice D - Roteiro de entrevista aplicado à Estagiária da Gerência da Articulação Privada da AGETUR (p. 102) 
4.4 Ministério do Turismo (MinTur)

De acordo com Zerbini (2005):

O conceito que o Ministério do turismo procura trabalhar é o seguinte: artesanato é todo o tipo de produto que é feito artesanalmente, incluindo arte popular e manualidades. Então é tudo que passa pelo processo manual e que é um artefato. O Ministério não inclui como artesanato a gastronomia local, pois daí estariam falando em produção artesanal.

O Ministério do Turismo é dividido em vários departamentos, mas o departamento que a produção artesanal está inserida é o de Qualificação, Certificação e de Produção Associada ao Turismo. O seu objetivo é trabalhar o artesanato associado ao turismo, ou seja, os locais que o turismo chega.

O Departamento de Qualificação, Certificação e de Produção Associada ao Turismo trabalha o produto associado, e um dos seus produtos é o artesanato. Temos no departamento então: jóias, couros e calçados, moda, cinema, manifestações culturais, alimentos e bebidas, artesanato, indústria têxtil, etc. Tudo o que pode se associar ao turismo.

Zerbini (2005) comenta:

No momento estamos tentando fortalecer e estruturar o artesanato como produto associado ao turismo. Então começaremos a participar das reuniões e dos Fóruns estaduais para disseminar e explicar como o Mintur trabalha o artesanato e também ensinaremos aos Estados como fazer um projeto para ser aprovado.

Portanto o que o Ministério do Turismo deseja, é estabelecer e definir o conceito que vai trabalhar, para dar oportunidades dos projetos dos Estados serem aprovados. Além do mais, este Ministério é um dos que tem maior empenho e poder de execução. 
Os projetos de artesanato realizados pelo MinTur são: Convênio com a Comissão de Turismo Integrada do Nordeste (CTI Nordeste); que é um programa de desenvolvimento da produção artesanal associada ao turismo, e um dos principais produtos artesanais é o artesanato; o Convênio com a AGETUR, que é um projeto de desenvolvimento do artesanato goiano para o turismo; Projeto Acre, Mato Grosso do Sul, e Paraná com a Fundação Banco do Brasil; o Instituto Estrada Real, onde trabalha um dos trechos da Estrada Real, etc.

O projeto da AGETUR juntamente com o apoio do MinTur tem por objetivo o desenvolvimento do artesanato de maneira adequada no Estado de Goiás. E um dos objetivos específicos deste projeto é a realização de oficinas de artesanato em 15 Municípios goianos. A primeira oficina já aconteceu em Pirenópolis, e o artesanato selecionado foi a cerâmica.

A AGETUR enviou o Projeto de Artesanato para o MinTur e este aprovou, apoiou e repassou um valor para o Estado.

Zerbini (2005) diz:

“O projeto acaba agora em julho de 2005, mas na verdade o que se pretende é que não seja um projeto que tenha começo e fim. É um projeto que o MinTur gostaria que o Estado de Goiás desse continuidade, e que as pessoas, os artesãos que participaram das oficinas sejam multiplicadores. Portanto é um projeto que envolve toda a comunidade".

Cada Município tem um teor, tem uma cultura, então o que se pretende com estas oficinas é fazer com que cada Município desenvolva o seu artesanato, e os Municípios que não tenha de raiz, que se defina com um design. E onde tiver artesanato de raiz o design não interfere, só qualifica e reestrutura para o turista. A qualificação e reestruturação devem ser feitas com cuidado para não se perder a identidade cultural e a autencidade do artesanato local. 
No ano de 2005 acontece 4 grandes eventos do Turismo no Brasil, são eles: Salão Brasileiro do Turismo em São Paulo, onde vão ser lançados os Roteiros do artesanato; Equipotel; Fórum Mundial de Turismo e o Congresso da ABAV.

Zerbini (2005) declara:

No Salão de Turismo vão ser comentados sobre os Roteiros de Artesanato que o MinTur está desenvolvendo. Estes roteiros contemplarão os artesanatos de todos os Estados. E será um roteiro no qual a pessoa viajará para conhecer apenas o artesanato local.

Zerbini acredita na invasão do turismo sem planejamento na vida dos artesãos, pois estes estão deixando de fazer os seus artesanatos para fazer outros que sejam mais vendáveis e mais atraentes aos olhos dos turistas.

Acredita-se que isso só vai mudar com a ajuda das autoridades governamentais e com a conscientização por parte dos artesãos de sua cultura.

Uma dificuldade que o MinTur enfrenta é a falta de informação das pessoas de como o MinTur trabalha o artesanato como produto associado e como é este trabalho.

Ver Apêndice E - Roteiro de entrevista aplicado à Consultora de Artesanato do Ministério do Turismo (p. 103) 
4.5 Ministério do Desenvolvimento, Indústria e Comércio Exterior (MinDIC)

De acordo com Novato (2005): "O artesanato é a representação mais simples da cultura e da identidade de um povo e que pode ser passado de geração a geração".

Em 1977, por meio do Decreto $n^{\circ}$ 80.098, de 8 de agosto de 1977. Foi criado um Programa Nacional de Desenvolvimento do Artesanato - PNDA, à época sob a responsabilidade do Ministério do Trabalho, que tinha como finalidade trabalhar o artesanato no Brasil.

Novato (2005) comenta:

Posteriormente foi editado o Decreto $\mathrm{n}^{\circ}$ 83.290, de 13 de março de 1979, que regulava a classificação de produtos artesanais e identificação profissional do artesão. Em 21 de março de 1991, por meio de um Decreto sem número, publicado no Diário Oficial de 22 do mesmo mês e ano, foram revogados os Decretos retrocitados e instituído o Programa do Artesanato Brasileiro - PAB, no âmbito do extinto Ministério da Ação Social.

Com o passar dos anos houve a necessidade de uma outra publicação, o Decreto $\mathrm{n}^{\circ}$ 1.508, de 31 de maio de 1995, o qual o PAB passou a ser vinculado ao Ministério da Indústria, do Comércio e do Turismo, que mais tarde foi substituído pelo Ministério do Desenvolvimento, Indústria e Comércio Exterior - MinDIC. (Ver Anexo C, p. 111)

Conforme o PAB:

As políticas estabelecidas para o segmento artesanal brasileiro, pelo Ministério do Desenvolvimento, Indústria e Comércio Exterior, estão voltadas para a organização e o fortalecimento dos núcleos de produção (associações e cooperativas de artesãos), bem como para a promoção e o incentivo à comercialização de produtos artesanais, em consonância com as diretrizes definidas para o segmento das micro e pequenas empresas: a geração de emprego, ocupação e renda; o estímulo à exportação; o desenvolvimento e o aproveitamento das vocações regionais/locais. o fortalecimento dos arranjos produtivos locais; e a integração regional e internacional. (http://www.pab.gov.br) 
Para a implementação destas políticas envolveu-se o Governo Federal, Estados, Municípios e entidades privadas.

Hoje o Ministério do Desenvolvimento trabalha o artesanato por meio do Programa do Artesanato Brasileiro (PAB).

O PAB é um programa que tem por finalidade coordenar e desenvolver atividades que valorizem o artesão brasileiro, elevando o seu nível cultural, profissional, social e econômico, e, ainda, promover e divulgar o artesanato brasileiro. E sua estrutura é a seguinte: Coordenação geral que é no MinDIC, que está vinculado ao Departamento de Pequenas e Micro Empresas e cada Estado tem uma Coordenação estadual, que normalmente é vinculado à Secretaria de Trabalho ou Secretaria de Indústria e Comércio do Estado.

\section{Segundo o PAB:}

O Programa estimula o aproveitamento das vocações regionais, levando à preservação das culturas locais e à formação de uma mentalidade empreendedora, por meio da preparação das organizações e de seus artesãos para o mercado competitivo. Para tanto, o PAB vem implementando suas ações em parceria com as Coordenações Estaduais de Artesanato dos 26 Estados e do Distrito Federal (http://www.pab.gov.br)

Portanto existe a Coordenação geral e as Coordenações estaduais e todas trabalham em parceria para melhor promover e divulgar o artesanato no Brasil.

A Coordenação geral do PAB dá autonomia para as Coordenações estaduais agirem da maneira que acharem melhor. Eles levam os produtos mais característicos da cultura de cada região para as feiras, ou seja, os produtos mais interessantes a serem mostrados e comercializados. 
Novato (2005) comenta: "Não existe um critério de escolha do artesanato pela Coordenação geral do PAB. Isso fica a critério de cada Coordenação estadual, pois eles estão mais próximos da realidade local".

O PAB trabalha 0 artesanato brasileiro da seguinte maneira: Primeiro as Coordenações estaduais procuram a Coordenação geral e falam o que necessitam. Depois a Coordenação geral envia um modelo de projeto para eles, em seguida, as Coordenações estaduais mandam os seus projetos. A Coordenação geral analisa o projeto e abri um processo para ver se é viável e se for o projeto é colocado em prática.

Novato (2005) diz:

O PAB repassa o dinheiro para os Estados na medida que os projetos vão chegando e vão sendo analisados e viáveis. Não tem uma quantidade certa a ser repassada para os Estados, depende de cada projeto. Tem Estados que recebe mais e outros menos.

O PAB está com alguns projetos de capacitação e feiras em andamento, como por exemplo a Feiart - Feira em Curitiba que aconteceu em abril. O PAB alugou um espaço ou um estande que se chama Espaço Brasil e que teve por finalidade levar as 27 Coordenações estaduais para exposições do artesanato. O objetivo do Espaço Brasil é estar em várias feiras do Brasil.

Novato (2005) declara: "O PAB ministra vários cursos de capacitação, como: Agentes de exportação, que foi realizado em março deste ano".

O Programa de Artesanato também apóia várias feiras nacionais, regionais, como por exemplo a Feira em Guarapari de Artesanato; Feira em Santa Catarina, eventos na Embaixada da Espanha: Nordeste mostra seu artesanato, que foi feito em parceria com o MinTur; fez um evento o ano passado juntamente com o SEBRAE no dia do artesão; projetos de capacitação no Espaço Brasil; a Feneart em Pernambuco, que é da Secretaria; Feira de Artesanato Monge Minas; alguns 
projetos com as prefeituras municipais; entre outros. Estas feiras sempre contam com o Espaço Brasil.

As empresas privadas também podem organizar e estruturar feiras, mas sempre com a aprovação das coordenações estaduais do PAB.

De acordo com Novato (2005): "O PAB trabalha a comercialização e a divulgação do artesanato praticamente em feiras e propicia para os artesãos melhoria de suas rendas e divulgação da cidade e cultura local".

Portanto o que pôde-se constatar é que o MinDIC, por meio do PAB trabalha apenas a divulgação e a comercialização do artesanato, ou seja, trabalha qualquer artesanato que seja selecionado pelas Coordenações estaduais para estarem em exposições e feiras, enquanto o MinTur, trabalha o artesanato como produto associado ao turismo.

Existe um projeto futuro do PAB que é o Projeto do Artesanato em Presídios. Este projeto contribuirá para a renovação dos presidiários como cidadãos, pois alguns presos fazem artesanato e o PAB quer fazer exposições nos presídios para capacitá-los. Esta capacitação acontecerá por meio de cursos e palestras.

O turismo é visto pelo MinDIC como benefício ao artesanato, pois aumenta a produção artesanal da cidade, divulga bastante o trabalho dos artesãos e contribui para o surgimento de novos.

Uma das maiores dificuldades enfrentadas pelo artesanato é a sua descaracterização, a sua perda de valores. Por isso tem que se tomar muito cuidado quando vai trabalhar, divulgar e comercializar o artesanato brasileiro.

Ver Apêndice F - Roteiro de entrevista aplicado à Auxiliar Administrativa do PAB (p. 104) 


\subsection{SEBRAE Nacional}

Mascêne (2005) comenta:

"O SEBRAE Nacional define artesanato como toda atividade produtiva que resulte em objetos e artefatos acabados, feitos manualmente ou com a utilização de meios tradicionais ou rudimentares, com habilidade, destreza, qualidade e criatividade".

Para melhor trabalhar e organizar o artesanato brasileiro o SEBRAE Nacional trabalha com o Programa SEBRAE de Artesanato em 27 Estados e tem parcerias com várias entidades como, ONG's; os SEBRAE's estaduais; empresas privadas; como a Infraero, Caixa Econômica, com o PAB, o MinTur, Banco do Brasil, etc. E também trabalha com o Projeto Arte Sol.

De acordo com o Documento SEBRAE (2004, p.15-16)

O Programa SEBRAE de Artesanato visa contribuir para o desenvolvimento sustentável do setor artesanal como estratégia de promoção cultural, econômica e social dos territórios. Seu objetivo é fomentar o artesanato de forma integrada, enquanto setor econômico sustentável que valoriza a identidade cultural das comunidades e promove a melhoria da qualidade de vida, ampliando a geração de renda e postos de trabalho.

O Programa SEBRAE de Artesanato foi criado em 1999 e é voltado para o desenvolvimento do artesanato, contribuindo para a preservação da cultura local. Ele trabalha o design do artesanato, mas com uma visão de negócios.

Mascêne (2005) diz: "Cada comunidade que se trabalha é colocado antropólogos e sociólogos que estudam a cultura, a tradição e as vezes são resgatadas culturas antigas, ou o que é expressivo em determinados locais". 
Seria, portanto, inserir a cultura ou uma característica expressiva nos produtos. Com isso os artesãos venderiam o que representa sua cultura, sua maneira de sentir e agir, sua história e é isso que diferencia um país do outro, um estado do outro.

A estrutura do Programa SEBRAE de Artesanato é a seguinte: Diretoria executiva SEBRAE Nacional, Grupo Gestor Nacional, Grupo Consultivo, Grupos de Trabalho, as Coordenações estaduais e as Gerências estaduais.

Conforme Mascêne (2005):

O Programa SEBRAE de Artesanato trabalha os produtos artesanais em categorias: origem, uso e destino. Quanto à origem o produto artesanal pode ser classificado em: arte popular, artesanato, trabalhos manuais, produtos alimentícios (típicos), produtos semi-industriais e indústrias (industrianato), artesanato indígena, artesanato tradicional, artesanato indígena, artesanato de referência cultural e artesanato conceitual. Quanto ao uso o produto artesanal pode ser classificado em: adornos e acessórios, decorativo, educativo, lúdico, religioso e utilitário. E quanto ao seu destino, conforme as localidades que tenham artesanato.

O outro Programa de artesanato que o SEBRAE Nacional trabalha é o Projeto Arte e Sol e funciona mais ou menos igual ao Programa SEBRAE de Artesanato, só que ele é voltado para o resgate de tradições antigas. Este projeto adequa o produto para o mercado, mas tenta mecher sem interferir ou descaracterizar o produto local.

O SEBRAE tem também projetos de parceria com empresas privadas, como é o caso da Infraero. O projeto era dispor de lojas de artesanato nos principais aeroportos brasileiros. E o papel do SEBRAE foi fornecer dados, materiais e informações. Um outro projeto que o SEBRAE participa é com a Caixa Econômica 
e o Banco do Brasil. Ele procura fornecer dados e informações para estas empresas.

Mascêne (2005) comenta:

Um outro Projeto que o SEBRAE Nacional apóia é o das "Feiras de artesanato" em 15 Municípios goianos. Ele é realizado em parceria com a AGETUR e o SEBRAE estadual. E visa capacitar artesãos locais e confrontá-los para a nova realidade artesanal. A primeira feira aconteceu em Pirenópolis e tinha como artesanato em exposição, a cerâmica. (Ver Anexo tal)

O SEBRAE Nacional juntamente com o PAB tem um projeto futuro para o artesanato brasileiro. O projeto tem como objetivo a realização de um Fórum Nacional do artesanato, que seja capaz de ser discutido por uma legislação voltada para as questões do memso.

Mascêne (2005) diz: "A legislação também será discutida pelos artesãos e Associações de artesanato de todo o Brasil".

O turismo contribui para o desenvolvimento e a comercialização do artesanato, além de proporcionar o surgimento de novos artesãos.

Um ponto importante sobre as condições em que os artesãos se encontram hoje, seria a dificuldade de se organizarem em Associações. A organização facilitaria uma melhor comercialização e a divulgação de seus produtos.

Ver Apêndice G - Roteiro de entrevista aplicado à Assessora do Dep. de Desenvolvimento Setorial do SEBRAE (p. 105) 


\section{CONSIDERAÇÕES FINAIS}

Pôde-se observar no decorrer da pesquisa, que o artesanato local de Pirenópolis faz parte da cultura, da tradição, da identidade cultural e do patrimônio imaterial da cidade. Cultura, por integrar a vida da comunidade pirenopolina desde muitos anos, quando os ensinamentos e os conhecimentos dos mais antigos foram assimilados e o artesanato começou a ganhar destaque na cidade. Tradição, por ser um conhecimento passado de geração a geração, ano após ano. Identidade cultural, por constituir traços culturais, por meio dos quais os membros da comunidade local se identificam. E patrimônio, por ser um bem imaterial que agrega valores à vida da comunidade local, tirando-a da rotina e despertando-a para a consciência de preservação.

Verificou-se que os principais tipos de artesanato encontrados em Pirenópolis foram: cerâmica, escultura em pedra, tapetes e colchas de retalho, tecelagem, máscara de papel, móveis rústicos, jóias de prata, pinturas e doces. E observouse também que com o passar dos anos foram surgindo vários tipos de artesanato e que este teve influências do "estrangeiro". Os estrangeiros foram considerados todas as pessoas que vieram de outros estados e países para Pirenópolis, como: argentinos, espanhóis, colombianos, uruguaianos, mineiros, paulistas, etc.

Portanto, os objetivos da pesquisa realizada foram alcançados, pois permitiu-se conhecer um pouco mais da história da cidade e esclareceu-se sobre o verdadeiro sentido do artesanato para os artesãos e para a comunidade pirenopolina. Além disso, os objetivos procuraram demonstrar que o artesanato foi sendo adaptado de acordo com as necessidades locais e o turismo, mas preservando suas origens.

Constatou-se também que o artesanato local é um dos atrativos principais do local, pois contribuiu e ainda contribui para o aumento do fluxo turístico na cidade. E que com o aumento deste fluxo, acelerou o processo de contínua invenção e 
reinvenção da arte, da tradição, dos valores, dos costumes, enfim, da cultura. Observou-se ainda que os artesãos locais avaliaram esta aceleração de forma positiva, pois permitiram a eles geração de renda e de emprego e conseqüentemente melhoria de suas vidas.

Quanto aos órgãos governamentais entrevistados, percebeu-se que valorizam o artesanato como cultura, tradição, identidade cultural, ou seja, como patrimônio cultural, mas que não é registrado como tal.

Acredita-se que ainda, que pode ser feito muita coisa por estes órgãos para que envolva a comunidade e a desperte para a preservação, como políticas mais adequadas e eficientes de preservação do artesanato, cursos, oficinas, palestras constantes às comunidades das diversas cidades do país, etc.

Pôde-se dizer então, que as tradições de Pirenópolis, em especial o artesanato contribui para o fortalecimento da goianidade, por meio dos costumes trazidos pelos pais, avós, bisavós e povos de outras culturas, dentre eles, argentinos, espanhóis, colombianos, uruguaianos, mineiros, paulistas, etc, que se fixaram na região e hoje vivem harmoniosamente com os pirenopolinos. Portanto, a goianidade é formada por meio das tradições locais e culturas herdadas de diferentes povos, pela participação popular e também pela ajuda e apoio dos órgãos públicos.

Enfim, com todas as análises feitas no decorrer do trabalho, compreendeu-se melhor os aspectos da cultura local e de que forma esta comunidade organizou e ainda organiza a sua história. 
APÊNDICES 


\section{APÊNDICE A}

Roteiro de entrevista semi-dirigida: Artesãos

Data:

Tipo de artesanato:

1. O que é artesanato e o que representa para o Sr/Sra?

2. Como o Sr faz o seu artesanato? (materiais utilizados e técnicas)

3. Como o Sr. aprendeu a trabalhar na atividade artesanal? (tradição familiar, cursos, com amigos, mestres ou outro artesão)

4. Há quanto tempo o Sr. trabalha como artesão?

5. Como o Sr. costuma divulgar os seus produtos? (amigos, associações, folhetos, jornal, televisão, feiras, rádio, internet, etc)

6. O Sr exerce outra atividade/profissão?

7. O Sr é cadastrado na Associação de Joalheiros e Artesãos de Pirenópolis $(\mathrm{AJAP}) ?$

8. Qual o motivo que o fez se cadastrar na Associação?

9. O Sr acha que o seu artesanato teve influencia dos "estrangeiros" (pessoas de outros estados ou países)? Quais?

10. Em que medida o turismo influencia o artesanato local em Pirenópolis?

11. O que o artesanato local tem proporcionado para a cidade de Pirenópolis?

12. Quais as maiores dificuldades que o Sr enfrenta com o artesanato?

13. O que o $\mathrm{Sr}$ acha que poderia ser feito para melhorar e/ou divulgar o artesanato local de Pirenópolis?

14. O Sr acha que as autoridades locais têm dado atenção ao artesanato local de Pirenópolis? 


\section{APÊNDICE B}

Roteiro de entrevista semi-dirigida

Data:

Órgão: Secretaria de Turismo de Pirenópolis

Cargo: Secretário de Turismo

1. O que é artesanato para o $\mathrm{Sr} / \mathrm{Sr}^{\mathrm{a}}$. ?

2. O que representa o artesanato para a comunidade local (artesãos) de Pirenópolis?

3. Quais são os principais tipos de artesanato existentes em Pirenópolis?

4. O artesanato local teve influência dos "estrangeiros" (pessoas de outros estados ou países)? Quais?

5. O que o artesanato local tem proporcionado para a cidade de Pirenópolis?

6. Existe algum projeto sendo feito pela Secretaria de Turismo para beneficiar o artesanato local de Pirenópolis?

7. Em que medida o turismo influencia o artesanato local em Pirenópolis?

8. O que o $\mathrm{Sr}$ acha que poderia ser feito para melhorar e/ou divulgar o artesanato local de Pirenópolis? 


\section{APÊNDICE C}

Roteiro de entrevista semi-dirigida

Data:

Órgão: Associação de Joalheiros e Artesãos de Pirenópolis (AJAP)

Cargo: Presidente da Associação

1. O que é artesanato para o $\mathrm{Sr} / \mathrm{Sr}^{\mathrm{a}}$. ?

2. O que representa o artesanato para a comunidade local (artesãos) de Pirenópolis?

3. Quais são os principais tipos de artesanato existentes em Pirenópolis?

4. Como, quando e por que surgiu a Associação de Joalheiros e Artesãos de Pirenópolis (AJAP)?

5. Por que o destaque para Joalheiros?

6. Qual a estrutura da Associação? Cargos e funções

7. Quantos e quem são os artesãos cadastrados?

8.Como os artesãos fazem para se cadastrar?

9. Qual o motivo que o fez participar da Associação?

10. Em que medida o turismo influencia o artesanato local em Pirenópolis?

11. O artesanato local teve influência dos "estrangeiros" (pessoas de outros estados ou países)? Quais?

12. O que o artesanato local tem proporcionado para a cidade de Pirenópolis?

13. O que o $\mathrm{Sr}$ acha que poderia ser feito para melhorar e/ou divulgar o artesanato local de Pirenópolis? 


\section{APÊNDICE D}

Roteiro de entrevista semi-dirigida

Data:

Órgão: Agência Goiana de Turismo (AGETUR)

Cargo: Estagiária da Gerência da Articulação privada

1. O que representa o artesanato para o $\mathrm{Sr} / \mathrm{Sr}^{\mathrm{a}}$. ?

2. Como a Agência Goiana de Turismo (AGETUR) trabalha o artesanato?

3. Quais os projetos ou programas de artesanato realizados pela AGETUR?

4. Existe algum projeto ou programa específico para o artesanato de Pirenópolis?

5. Existe algum projeto futuro para o artesanato de Pirenópolis?

6. Em que medida o turismo influencia o artesanato local em Pirenópolis?

7. Quais as maiores dificuldades enfrentadas pelo artesanato em Pirenópolis? 


\section{APÊNDICE E}

Roteiro de entrevista semi-dirigida:

Data:

Órgão: Ministério do Turismo (MinTur)

Cargo: Consultora em Artesanato

1. O que representa o artesanato para o $\mathrm{Sr} / \mathrm{Sr}^{\mathrm{a}}$. ?

2. Como o Ministério do Turismo (MinTur) trabalha o artesanato?

3. Quais os projetos ou programas de artesanato realizados pelo MinTur?

4. Quais os critérios utilizados pelo MinTur para avaliar os diversos tipos de artesanato?

5. Existe algum projeto ou programa específico para o artesanato de Pirenópolis?

6. Existe algum projeto futuro para o artesanato brasileiro?

7. Em que medida o turismo influencia o artesanato brasileiro?

8. Quais as maiores dificuldades enfrentadas pelo artesanato no Brasil? 


\section{APÊNDICE F}

Roteiro de entrevista semi-dirigida

Data:

Órgão: Ministério do Desenvolvimento, Indústria e Comércio Exterior (MinDIC) Cargo: Auxiliar Administrativa do PAB

1. O que representa o artesanato para o $\mathrm{Sr} / \mathrm{Sr}^{\mathrm{a}}$. ?

2. Como o Ministério do Desenvolvimento, Indústria e Comércio (MinDIC) trabalha o artesanato?

3. Quais os projetos ou programas de artesanato realizados pelo MinDIC?

4. O que é o Programa de Artesanato Brasileiro (PAB), como surgiu, quando foi criado e por quê?

5. Qual a estrutura do PAB e quem são os responsáveis?

6. Quais os objetivos do PAB?

7. O que o PAB propicia para a comunidade de um determinado local, cidade ou região?

8. Quais os critérios utilizados pelo MinDIC para avaliar os diversos tipos de artesanato?

9. Existe algum projeto ou programa específico para o artesanato de Pirenópolis?

10. Existe algum projeto futuro para o artesanato brasileiro?

11. Em que medida o turismo influencia o artesanato brasileiro?

12. Quais as maiores dificuldades enfrentadas pelo artesanato no Brasil? 


\section{APÊNDICE G}

Roteiro de entrevista semi-dirigida

Data:

Órgão: SEBRAE Nacional

Cargo: Assessora do Departamento de Desenvolvimento Setorial do SEBRAE

1. O que representa o artesanato para o $\mathrm{Sr} / \mathrm{Sr}^{\mathrm{a}}$. ?

2. Como o SEBRAE Nacional trabalha o artesanato?

3. Quais os projetos ou programas de artesanato realizados pelo SEBRAE Nacional?

4. O que é o Programa SEBRAE de Artesanato, como surgiu, quando foi criado e por quê?

5. Qual a estrutura do Programa SEBRAE de Artesanato e quem são os responsáveis?

6. Quais os objetivos do Programa SEBRAE de Artesanato?

7. O que o Programa SEBRAE de Artesanato propicia para a comunidade de um determinado local, cidade ou região?

8. Quais os critérios utilizados pelo SEBRAE Nacional para avaliar os diversos tipos de artesanato?

9. Existe algum projeto ou programa específico para o artesanato de Pirenópolis?

10. Existe algum projeto futuro para o artesanato brasileiro?

11. Em que medida o turismo influencia o artesanato brasileiro?

12. Quais as maiores dificuldades enfrentadas pelo artesanato no Brasil? 
APÊNDICE H

1. ${ }^{a}$ Exposição de Cerâmica realizada pela Secretaria de Turismo de Pirenópolis em parceria com a AGETUR

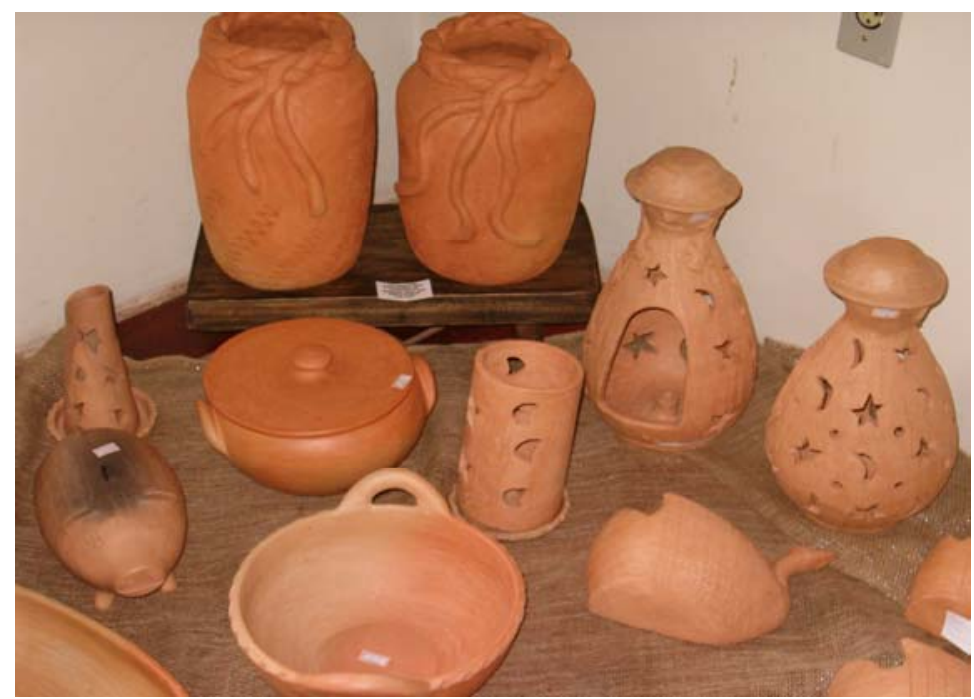

Fonte: Rodrigues, Ludmilla. Pirenópolis. 31 de março de 2005

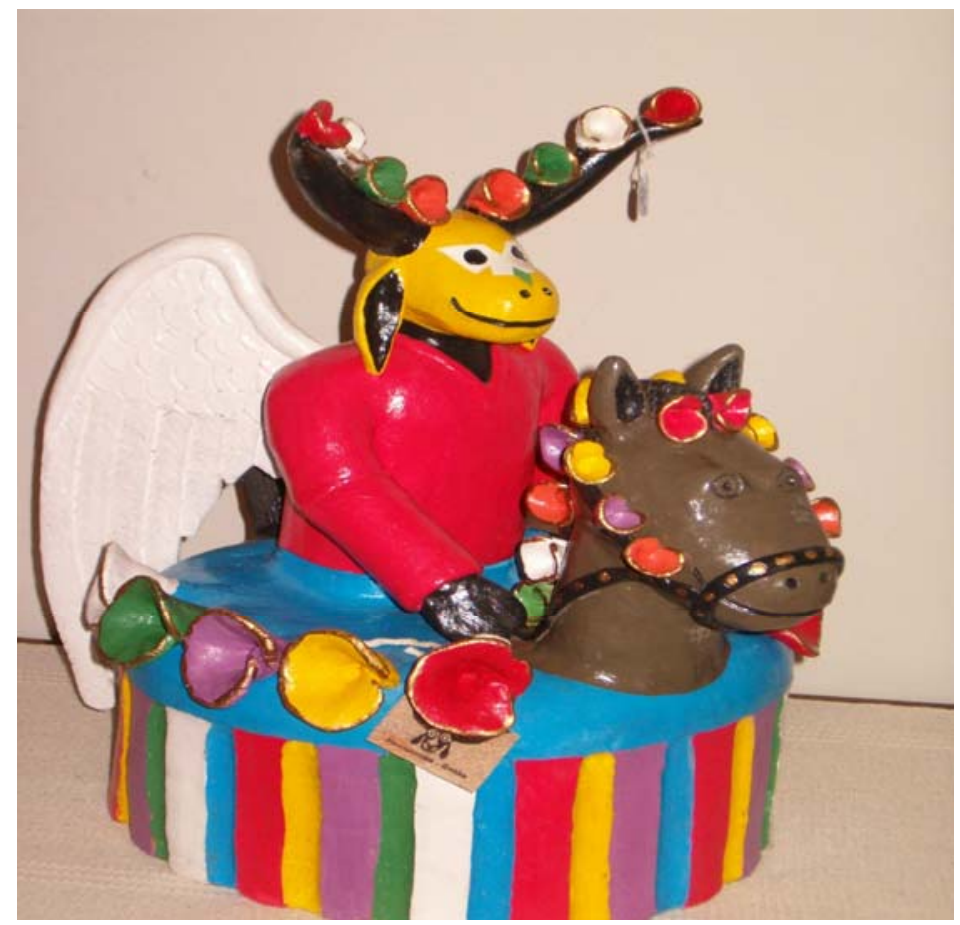

Fonte: Rodrigues, Ludmilla. Pirenópolis. 31 de março de 2005 


\section{REFERÊNCIAS BIBLIOGRÁFICAS}

ABREU, Lunildes de Oliveira. Artesã: entrevista [30 mar. 2005]. Entrevistadora: L. Rodrigues. Pirenópolis, 2005. 1 cassete sonoro;

ABREU, Regina. Performance e patrimônio intangível: Os Mestres da Arte. In: TEIXEIRA, João Gabriel L. C., et al (orgs), Patrimônio imaterial, performance cultural e (re) tradicionalização. Brasília: ICS-UNB, 2004;

ARANTES, Antônio Augusto. O que é cultura popular? 14 a ed. São Paulo: Brasiliense, 1990;

AYER, Evandro Engel. Secretário de Turismo de Pirenópolis: entrevista [31 mar. 2005]. Entrevistadora: L. Rodrigues. Pirenópolis, 2005. 1 cassete sonoro;

AUGÉ, Marc. Não-lugares: introdução a uma antropologia da sobremodernidade. Bertrand, 1994;

BARRETO, Margarita. Turismo e legado cultural. $3^{\text {a }}$ ed. São Paulo: Papirus, 2002;

BENI, Mário Carlos. Análise Estrutural do Turismo. 4ªed. São Paulo: SENAC, 2001;

BO, João Batista Lanari. Proteção do Patrimônio na UNESCO: ações e significados. Brasília: UNESCO, 2003;

COUTINHO, Graça. Mosaico da memória. In: LONDRES Cecília (org), Revista Tempo brasileiro - Patrimônio imaterial $\mathbf{n}^{\circ}$ 147. Rio de Janeiro: Tempo Brasileiro, 2001;

DELPHIM, Carlos Fernando de Moura. Apostila: Apropriação de Espaços no Lazer e no Turismo. Brasília: UNB, 2004;

FERREIRA, Aurélio Buarque de Holanda. Dicionário da Língua Portuguesa. $2^{\mathrm{a} e d .}$ Rio de Janeiro: Nova Fronteira, 2004;

FORZANI, Pércio. Artesão: entrevista [30 mar. 2005]. Entrevistadora: L. Rodrigues. Pirenópolis, 2005. 1 cassete sonoro;

FUNARI, Pedro Paulo; PINSKY, Jaime. Turismo e Patrimônio Cultural. $3^{\mathrm{a}}$ ed. São Paulo: Contexto, 2003; 
GOULÃO, Doraluzia de Oliveira. Arteso: entrevista [31 mar. 2005]. Entrevistadora: L. Rodrigues. Pirenópolis, 2005. 1 cassete sonoro; GRUNEWALD, Rodrigo de Azeredo. Turismo e o "resgate" da cultura Pataxó. In: BANDUCCI, Álvaro Jr; BARRETO Margarita (orgs), Turismo e identidade local: uma visão antropológica. Campinas, SP: Papirus, 2001;

http://www.eba.ufmg.br/alunos/kurtnavigator/arteartesanato/artesanato.html. Acesso em: 20 de set. 2004;

http:// www.pirenopolis.tur.br. Acesso em: 7 de jun. 2004;

http://wmail.faac.unesp.br/ pcampos/oqueecomunidade.htm. Acesso em: 23 de mar. 2005;

http://www.iphan.gov.br. Acesso em: 11 de abr. 2005;

http://pab.desenvolvimento.gov.br. Acesso em: 12 de abr. 2005;

LARAIA, Roque de Barros. Cultura: um Conceito Antropológico. $8^{a}$ ed. Rio de Janeiro: Jorge Zahar, 1993;

LOBO, Élio Souza. Artesão: entrevista [31 mar. 2005]. Entrevistadora: L. Rodrigues. Pirenópolis, 2005. 1 cassete sonoro;

LONDRES, Cecília. Para além da "pedra e cal": por uma concepção ampla de patrimônio. In: LONDRES Cecília (org), Revista Tempo brasileiro - Patrimônio imaterial $n^{\circ}$ 147. Rio de Janeiro: Tempo Brasileiro, 2001;

LONDRES, Cecília. Patrimônio e performance: uma relação interessante. In: TEIXEIRA, João Gabriel L. C., et al (orgs), Patrimônio imaterial, performance cultural e (re) tradicionalização. Brasília: ICS-UNB, 2004;

MAGALHÃES, Aloísio. E triunfo? A questão dos bens culturais no Brasil. Rio de Janeiro: Nova Fronteira, 1997;

MASCÊNE, Durcelice Cândida, et al (orgs). Documento Programa SEBRAE de Artesanato. Araxá,MG: SEBRAE, 2004;

MASCÊNE, Durcelice Cândida. Assessora do Dep. de Desenvolvimento Setorial do SEBRAE: entrevista [6 abr. 2005]. Entrevistadora: L. Rodrigues. Brasília, 2005. 1 cassete sonoro;

MONTEIRO, Mercedes. Artesã: entrevista [29 mar. 2005]. Entrevistadora: L. Rodrigues. Pirenópolis, 2005. 1 cassete sonoro; 
NOVATO, Mariana Silva. Auxiliar Administrativa do PAB - MinDIC: entrevista [5 abr. 2005]. Entrevistadora: L. Rodrigues. Brasília, 2005. 1 cassete sonoro;

OLIVEN, Ruben George. Patrimônio intangível: considerações iniciais. In: ABREU, Regina; CHAGAS, Mário (orgs), Memória e Patrimônio. Rio de Janeiro: DP\&A, 2003;

PEREIRA, Balduíno Valério. Artesão: entrevista [29 mar. 2005]. Entrevistadora: L. Rodrigues. Pirenópolis, 2005. 1 cassete sonoro;

PEREIRA, Balduíno Valério. Presidente da Associação de Joalheiros e Artesãos de Pirenópolis (AJAP): entrevista [31 mar. 2005]. Entrevistadora: L. Rodrigues. Pirenópolis, 2005. 1 cassete sonoro;

PINA, João Luiz Pompeu. Artesão: entrevista [30 mar. 2005]. Entrevistadora: L. Rodrigues. Pirenópolis, 2005. 1 cassete sonoro;

PINTO, Roque Pereira. Artesão: entrevista [29 mar. 2005]. Entrevistadora: L. Rodrigues. Pirenópolis, 2005. 1 cassete sonoro;

ROSS, Glenn F. Psicologia do Turismo. São Paulo: Contexto, 2001;

SANT'ANNA, Márcia. A fase imaterial do patrimônio cultural: os novos instrumentos de reconhecimento e valorização. In: ABREU, Regina; CHAGAS, Mário (orgs), Memória e Patrimônio. Rio de Janeiro: DP\&A, 2003;

SILVA, Maria Conceição Pereira. Artesã: entrevista [29 mar. 2005]. Entrevistadora: L. Rodrigues. Pirenópolis, 2005. 1 cassete sonoro;

VELOSO, Mariana Barreto. Estagiária da Gerência da Articulação Privada da AGETUR: entrevista [18 maio. 2005]. Entrevistadora: L. Rodrigues. Goiânia, 2005. 1 cassete sonoro;

VELOSO, Mariza. Apostila: Apropriação de Espaços no Lazer e no Turismo. Brasília: UNB, 2004;

VELOSO, Mariza. Patrimônio Imaterial, memória coletiva e espaço público. In: TEIXEIRA, João Gabriel L. C., et al (orgs), Patrimônio imaterial, performance cultural e (re) tradicionalização. Brasília: ICS-UNB, 2004;

VIANNA, Letícia. Pluralidade cultural e identidade nacional: um relato de experiências recentes de políticas no Brasil. In: TEIXEIRA, João Gabriel L. C., et al 
(orgs), Patrimônio imaterial, performance cultural e (re) tradicionalização. Brasília: ICS-UNB, 2004;

ZERBINI, Ana. Consultora de Artesanato do MinTur: entrevista [5 abr. 2005]. Entrevistadora: L. Rodrigues.Brasília, 2005. 1 cassete sonoro. 
ANEXOS

ANEXO A - Artesãos cadastrados na Associação de Joalheiros e Artesãos de Pirenópolis;

ANEXO B - Cópia do Projeto de Desenvolvimento do Artesanato Goiano;

ANEXO C - Decreto $n^{\circ} 83.290$, de 13 de março de 1979 e Decreto $n^{\circ} 1.508$, de 31 de maio de 1995. 